\title{
Punctuated Neogene tectonics and stratigraphy of the African-Iberian plate-boundary zone: concurrent development of Betic-Rif basins (southern Spain, northern Morocco)
}

\author{
W. Sissingh \\ Faculty of Earth Sciences, Utrecht University, Budapestlaan 4, 3584 CD Utrecht, the Netherlands.
}

Manuscript received: March 2007; accepted: October 2008

\begin{abstract}
This paper integrates the sequence stratigraphic and tectonic data related to the Neogene geodynamic and palaeogeographic development of the African-Iberian plate boundary zone between Spain and Morocco. Though the dating of individual tectonostratigraphic sequences and their delimiting sequence boundaries varies in accuracy and precision, their apparent correlation strongly suggests contemporaneous development of the Betic and Rif basins. This may likely be attributed to regional changes of the overall compressional intra-plate stress field. This, in turn, was governed by coeval plate-kinematic changes related to the ongoing collisional convergence of Africa and Iberia. The Neogene succession is characterised by brief tectonic pulses that governed the sequence stratigraphic development of the Betic-Rif basins (NBR phases). It broadly correlates with the coeval sequences in the compressional foreland basins and extensional rift basins in front of the collisional Alpine and Pyrenean orogens (CRF phases). These regionally correlatable basinal deformation events indicate that stress-related episodic changes at the African-Iberian plate-boundary zone resulted in an essentially direct cause-and-effect relationship between the tectonostratigraphic evolution of Neogene basins in northern African (Morocco), southern Europe (Spain) and western Europe (France, Switzerland, Germany).
\end{abstract}

Keywords: Betic basins, Rif basins, Alboran Basin, tectonics, plate kinematics, stratigraphy, Neogene

\section{Introduction}

The geological configuration of the present-day Mediterranean is characterized by a complex and extensive system of both interconnected and fragmented fold-and thrust belts that is associated with back-arc basins (e.g. Carminati et al., 1998; Rosenbaum \& Lister, 2004). Their tectonic structure and setting are varied, and the compressional origin and growth of the different belts and the formation of the adjoining extensional basins also varies considerably in age. The different fold-andthrusts belts did not evolve during one single, uninterrupted cycle of Alpine orogenesis, but are the ultimate outcome of a prolonged, polyphase process of intermittent plate-tectonic interaction between the African-Arabian and Eurasian plates. This resulted in the creation and ultimate disappearance of two major oceanic basins, the Palaeotethys (mainly Palaeozoic) and the Neotethys (late Palaeozoic-Mesozoic). As in the preceding Jurassic and Cretaceous times, the motions of Africa-Arabia relative to Eurasia during the Tertiary were an important control on the geological evolution of the Alpine Tethys (late Mesozoic-Tertiary). Various kinematic frameworks for palaeotectonic and palaeogeographic reconstructions have been proposed for the region (e.g. Dewey et al., 1989; Rosenbaum et al., 2002). These were mostly based on analysis of rotation parameters (poles of rotation, rotation angles), which allowed to constrain past relative velocities between Africa and Eurasia. In addition, analysis of North Atlantic magnetic lineations helped to constrain the movement of Africa and Europe relative to North America. The consensus view is that during the Late Cretaceous Africa converged towards Europe in a S-N directed rotational mode. This was contemporaneous with spreading of the Azores part of the North Atlantic, the coeval opening of the Gulf of Biscay like a sphenochasm and the resulting anti-clockwise rotation of Iberia with respect to Eurasia. Sinistral motion occurred after an active plate boundary subject to left-lateral strike-slip faulting had been established at the northern margin of the Iberian block. Consequently, Iberia behaved like a promontory 
of Africa until the Middle Eocene (Srivastava et al., 1990; Roest \& Srivastava, 1991). The rotation of Iberia continued until the latest Cretaceous (Campanian).

Concurrently, Iberia drifted eastward together with Africa due to the opening of the Atlantic. The rotation ended with the onset of wholesale Africa-Europe convergence with the resulting Alpine compression climaxing in the African-Iberian plate-boundary zone during the Late Tertiary. There is, however, still uncertainty and debate as to when exactly the convergence began. In the earliest Tertiary, a major slow-down in the driving $\mathrm{N}$-S African-European plate convergence occurred contemporaneously with the Laramide orogeny (Rosenbaum et al., 2002). Subsequently, syn-drift dextral strike-slip motions occurred between Africa and Europe. The motion path of Africa during the remainder of the Tertiary was quite varied. Africa followed a SW-NE directed path until the Late Eocene period of enhanced continent-continent collision (Frizon de Lamotte et al., 2000). It took a roughly SSW-NNE directed path during the 'post-collisonal' Oligocene, a largely S-N directed path during the Miocene and a SSE-NNW directed path from the Late Miocene (Tortonian) onwards (Rosenbaum et al., 2002). Overall, the plate-kinematic interaction of Africa, Iberia and Europe resulted ultimately into major orogenic systems: the PyreneanCantabrian and Betic-Balearic mountain belts bordering the Iberian Microplate, and the Maghrebian (Rif-Tell) mountain range along the northern margin of the African Plate. Each of the formative phases of the progressive Alpine convergence and orogeny was associated in the Western Mediterranean with lithospheric deformation (shortening) and subduction in response to crustal compression between the African and European plates and the intermediate Iberian and Apulian microplates. From the Early Oligocene onwards this shortening and subduction was accompanied with generally eastwards propagating back-arc extension and rift basin formation. The latter process linked Late Oligocene basin formation in southern Spain to the opening of the Valencia Trough, which is the southern extension of the European Cenozoic Rift System offshore eastern Spain (Sanz de Galdeano, 1988, 1990a; Sissingh, 2006). More generally, the 'post-collisional' retreat of the subducting African lithospheric slab to the east induced the diachronous post-Neothethyan opening of the Western Mediterranean (e.g. Carminati et al, 1998; Rosenbaum \& Lister, 2004).

As a result, the plate-boundary zone between Spain and Morocco at present coincides with a complex zone of intense tectonic deformation. It reflects continent-continent collision (evidenced by penetrative shortening deformation, stacking of tectonic units and high-grade metamorphism; Banks \& Warburton, 1991; de Jong, 1991; Platt \& Whitehouse, 1999) and lithospheric subduction (inferred from seismic tomography; Blanco \& Spakman, 1993; Morales et al., 1999; Gutscher et al., 2002). This collision was associated with magmatic activity (generally related to transpression of strike-slip faults; Bordet,
1985; Hernandez \& Bellon, 1985; Torres-Roldán et al., 1986; Di Battistini et al., 1987; Hernandez et al., 1987; Chotin \& Ait Brahim, 1988; Aït Brahim \& Chotin, 1990; El Bakkali et al., 1998; Zeck et al., 2000; Fernández-Soler, 2001) in a large area still characterised by scattered, low-magnitude earthquakes (concentrated at pre-existing structural weakness zones and most frequently focused at shallow to intermediate depths; Buforn et al., 1988, 1995; Morales et al., 1997). These varied phenomena are all responses to geodynamic processes controlled by the Africa-Europe convergence (Argus et al., 1989; Morales et al., 1999; Calvert et al., 2000; Gutscher et al., 2002).

Plate-tectonic wise, Iberia was an independent microplate separate from Europe and Africa from the late Middle Eocene until the beginning of the Miocene (Srivastava et al., 1990; Roest \& Srivastava, 1991). In the earliest Miocene, its northern plate boundary became extinct and, as a consequence, the Iberian microplate became part of Europe. The Azores-Gibraltar Fault Zone then became the plate boundary between Africa and Europe (Srivastava et al., 1990; Roest \& Srivastava, 1991). Indeed, from the Azores up to approximately Gibraltar the boundary is relatively simple and well-defined. In the continental crust domain of the Betic-Rif orogen, the study area of this paper, the eastward continuation of the transpressional Azores-Gibraltar Fault Zone into the westernmost Mediterranean Basin is obscured by the complex collisional deformation of the continental lithosphere. This resulted in numerous, outwardly displaced crustal blocks that form an overall westward-vergent orocline around the Alboran Sea. The Alboran Sea is a region of strong subsidence floored by a relatively thin continental crust above an anomalously low-velocity upper mantle. It is characterised by low-angle intracrustal detachments and shallow normal faulting induced by Early to early Late Miocene extension (e.g. Galindo-Zaldivar et al., 1989; García-Dueñas et al., 1992; Comas et al., 1999; Torné et al., 2000). The exact location of the eastern plate-boundary sector has turned out to be very difficult to establish unambiguously. This is surprising as one would expect it to be a distinct, elongate transcurrent tectonic feature. Generally, it is assumed that the Azores-Gibraltar Fault Zone extends eastward through the Strait of Gibraltar. However, most authors have refrained from indicating the (approximate) location of the boundary fault zone to the south and east of Gibraltar. Contrary to the established opinion that the plate boundary evolved within the Alboran domain (see below), it has previously been argued that the plate-tectonic suture lies farther to the north or south. This uncertainty reflects the lack of consensus about the (3-D) structuration of the sub-Moho lithosphere beneath the almost 180? curvature of the Betic-Rif thrust belt. Consequently, the causal events responsible for the formation of the orogens are also poorly understood. Many different models and hypotheses have been proposed to explain the geodynamic development of the accretionary orogenic wedge (e.g. Doblas \& Oyarzun, 1989; Platt \& Vissers, 
1989; Boccaletti et al., 1990; Leblanc, 1990; Frizon de Lamotte et al., 1991; García-Dueñas et al., 1992; Docherty \& Banda, 1995; Seber et. al., 1996; Martínez-Martínez \& Azañón, 1997; Lonergan \& White, 1997; Zeck, 1997, 1999, Tandon et al., 1998; Comas et al., 1999; Calvert et al., 2000; Rosenbaum \& Lister, 2004). An origin involving late-orogenic extensional collapse of the inner part of an exotic 'Alboran Block' (accommodated by coeval thin-skinned thrusting in the South Iberian and Maghrebian foreland regions) has been assumed. The 'Alboran Block' was first interpreted by Andrieux et al. (1971) as the hanging-wall of a major thrust unit ('microplate') that moved over a long distance from the location of the North Algerian (or Balearic) Basin to the south-southwest. This accounts for the major E-W shortening in the Gibraltar thrust footwall and palaeorotations (see below). This microplate consists of metamorphic "hinterland thrusts' that are surrounded by essentially non-metamorphic 'foreland thrusts' in the footwall.

The following two groups of causative models, which are not necessarily mutually exclusive are distinguished:

1. Extension of the continental crust due to convective removal of (cold and dense) lithosphere beneath a fixed depocentre (Platt \& Vissers, 1989; Vissers et al., 1995) or by (asymmetric) delamination of the lithosphere beneath an eastwardmigrating depocentre (García-Dueñas et al., 1992; Docherty \& Banda, 1995; Seber et al., 1996). This was associated with the simultaneous gravitational collapse of thickened continental crust as well as extension-driven thrusting.

2. Subduction of the continental crust associated with backarc extension that was induced by the westward roll-back of an east-dipping sinking slab (Lonergan \& White, 1997; Rosenbaum \& Lister, 2004) or with uplift-related extension due to a break-off of the subducting slab (Zeck, 1997). This was associated with (simultaneous) asthenosphere-mantle upwelling and gravitational collapse of thinning continental crust and extension-driven thrusting.

Though the fact of plate convergence is unboubted, the vera causa of the circumstances and processes that led to the extensional collapse of the 'Alboran Block' remain controversial. The very large-scale of this event is particularly evidenced by the close vertical spacing of metamorphic grades and the major post-orogenic crustal attenuation of the 'Alboran Block'. The attenuation on the order of 15 and $20 \mathrm{~km}$ probably indicates very rapid cooling associated with exhumation of high-grade metamorphic rocks during the early Miocene, which was the main period of extension and subsidence of the Alboran Domain (Platt, 1998; Platt \& Whitehouse, 1999).

Given the paucity of hard data and the resulting interpretative uncertainties, various single-plate subduction/ collision systems have been proposed with the main dips directed southward (Sanz de Galdeano, 1990b; Morley, 1992; Morales et al. 1999), westward (Docherty \& Banda, 1995; Zeck, 1997, 1999) or eastward (Morley, 1993; Royden, 1993; Lonergan
\& White, 1997; Calvert et al., 2000; Gutscher et al., 2002). An alternative, double-plate subduction/collision model (cf. Torres-Roldán et al., 1986) has recently been re-introduced by Michard et al. (2002). In this double-plate model the continental plate margins are respectively dipping to the northwest (Maghrebian subduction; North African margin) and to the southeast (Betic subduction; South Iberian margin). Overall, the Betic-Rif orocline is interpreted as an intracontinental collision orogen including an allochthonous, roll-back related 'Alboran Block' situated right above a double-plate subduction zone and thus hiding the eastward continuation of the Azores-Gibraltar Fault Zone. The view that the African-Iberian plate boundary crosses the region of the Strait of Gibraltar and the Alboran Sea beneath a cover of allochthonous Alboran lithosphere (cf. Sanz de Galdeano, 2000) is (tentatively) adopted in this study. Given the rather tentative palinspastic reconstruction of the location of the plate contact between the African and Iberian plates during the Miocene and Pliocene, it is likely the plate boundary was a transpressional dextral transform fault since the Paleocene (Srivastava et al., 1990; Roest \& Srivastava, 1991; Meghraoui et al., 1996). It is clear though that there is no geometrically simple expression of the plate boundary east of the Strait of Gibraltar.

For this reason, this paper does not address the complex geodynamic origin of the oroclinal Betic-Rif structure. The principal goal of this study is to review for the first time the Neogene tectonostratigraphic evolution of the African-Iberian plate-boundary zone, covering both southern Spain (south of the Iberian Meseta) and northern Morocco (north of the Moroccan Meseta). In particular it analyses the contemporaneous plate-tectonic deformation history, including palaeogeographic developments. Special attention is given to the syn-kinematic sequence stratigraphy of the Betic-Rif basins, aiming at a tectonostratigraphic scenario for the African-Iberian plate boundary zone on the basis of the extensive open literature. Sequences and events are calibrated to the geological time scale of Gradstein et al. (2004).

\section{Structural setting}

The principal driving mechanism for the Late CretaceousCenozoic development of the Betic-Rif system was crustal deformation caused by the northward movement of Africa relative to Europe. The following crustal domains were involved in the formation of the tightly arcuate Betic-Rif chain of more or less isolated sierras (Figs 1 and 2):

1. South Iberian Domain: north of the Internal-External Zone Boundary. Comprises a thrust-and-fold belt with exposures of mostly non-metamorphic, sedimentary rocks of Mesozoic and Tertiary age, including lamproites of Miocene age.

2. Alboran Domain: Alboran Sea and thrust zone regions south of the Internal-External Zone Boundary and east of the Internal Rif Thrust Front. Mainly consisting of superimposed 
nappe complexes composed of various metamorphic rocks of Palaeozoic and Mesozoic (Triassic) age. Includes alkaline, (high-K) calc-alkaline, shoshonitic and ultrapotassic igneous rocks and lamproites of Miocene age.

3. Maghrebian Domain: west and south of the Internal Rif Thrust Front. Comprises non-metamorphic sedimentary rocks of Mesozoic and Tertiary age (cf. 1). Includes (hyper)alkaline, calc-alkaline and shoshonitic igneous rocks of Miocene and Pliocene age.

4. Campo de Gibraltar Flysch Domain: west to northeast of Gibraltar. Exposes non-metamorphic, deep-water sedimentary rocks of Jurassic, Cretaceous and Tertiary (PaleoceneMiocene) age.

5. Maghrebian Flysch Domain: south of Tanger and south to east of Jebha. Exposes sedimentary rocks of Jurassic to Tertiary age (cf. 4).

Based on differences in depositional history (types of rock), tectonometamorphic evolution (styles of deformation) and timing of Alpine deformation (origin of structures), the South Iberian and Maghrebian Domains and the Maghrebian
Flysch Domain are traditionally referred to as the External Zone while the Alboran Domain and the Campo de Gibraltar Flysch Domain are referred to as the Internal Zone (Fig. 2; Fallot, 1948). The intensity of deformation decreases markedly from the Internal Zone to the External Zone. The Internal Zone, the outcropping Spanish part of which is also called 'Betic Zone', consists essentially of fragments (allochthonous terranes) derived from a linear, collisional mountain chain (thick-skinned nappe stack) that originated in a distant northeastern position. Probably mostly during the Late Eocene 'Atlas Event' of enhanced collision of Africa and Europe in combination with increased NE-SW striking lithosphere-scale underthrusting (Vissers et al., 1995; Frizon de Lamotte et al., 2000). The 'Betic Zone' collapsed in 'mid-Oligocene' time at the beginning of $S$ and $\mathrm{W}$ directed back-arc extension in the Western Mediterranean (Rosenbaum \& Lister, 2004). It comprises a number of nappe complexes that represent a varied, pre-Neogene and Neogene tectonometamorphic history, including a record of penetrative syn-metamorphic deformation related to an alternation of compressional and extensional processes (Fig. 2; simplified, partly after Egeler \& Simon, 1969; Didon et al., 1973; Durand-

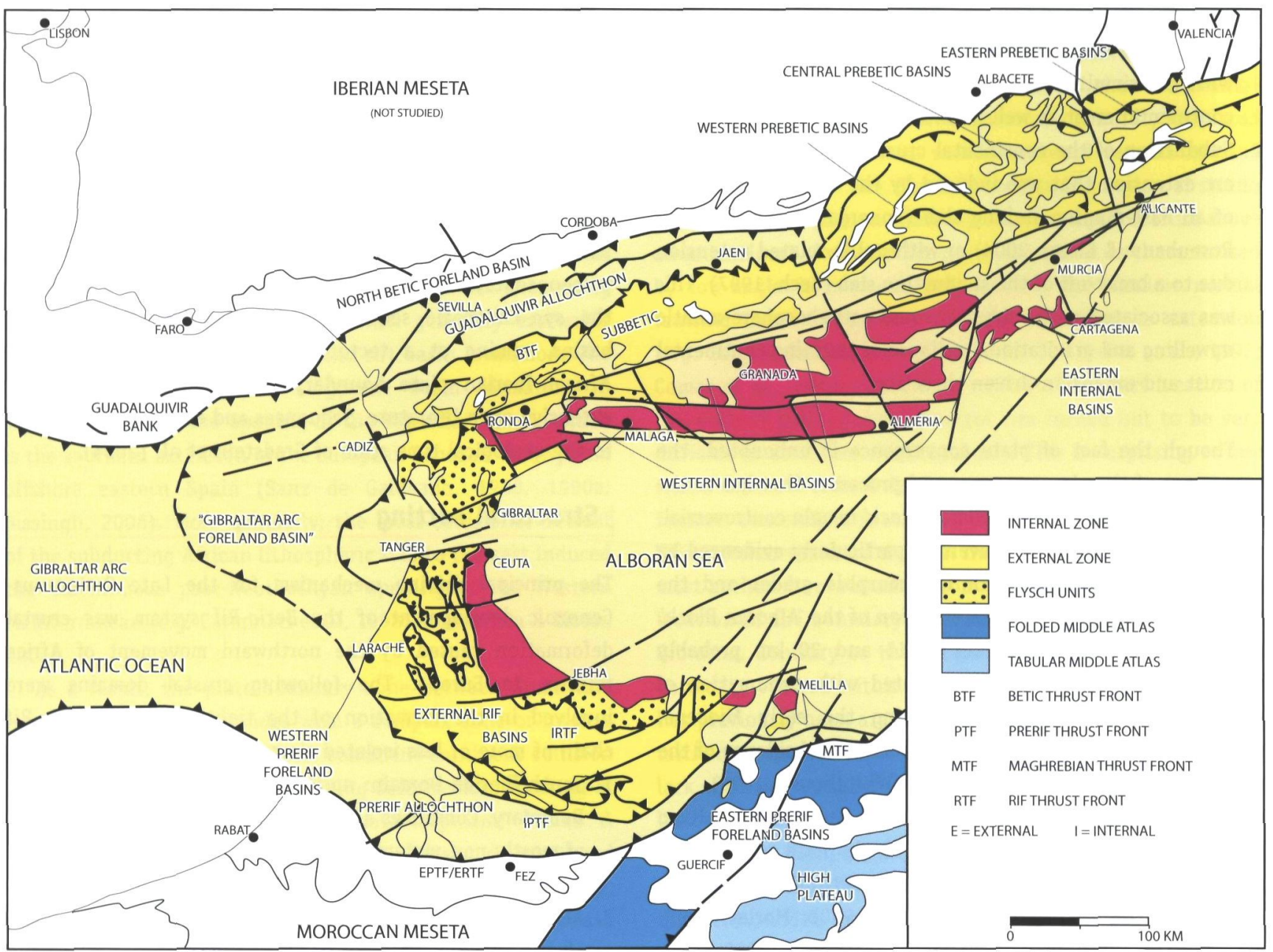

Fig. 1. Structural map of the principal tectonic elements and basinal areas of the Betic-Rif orocline. 


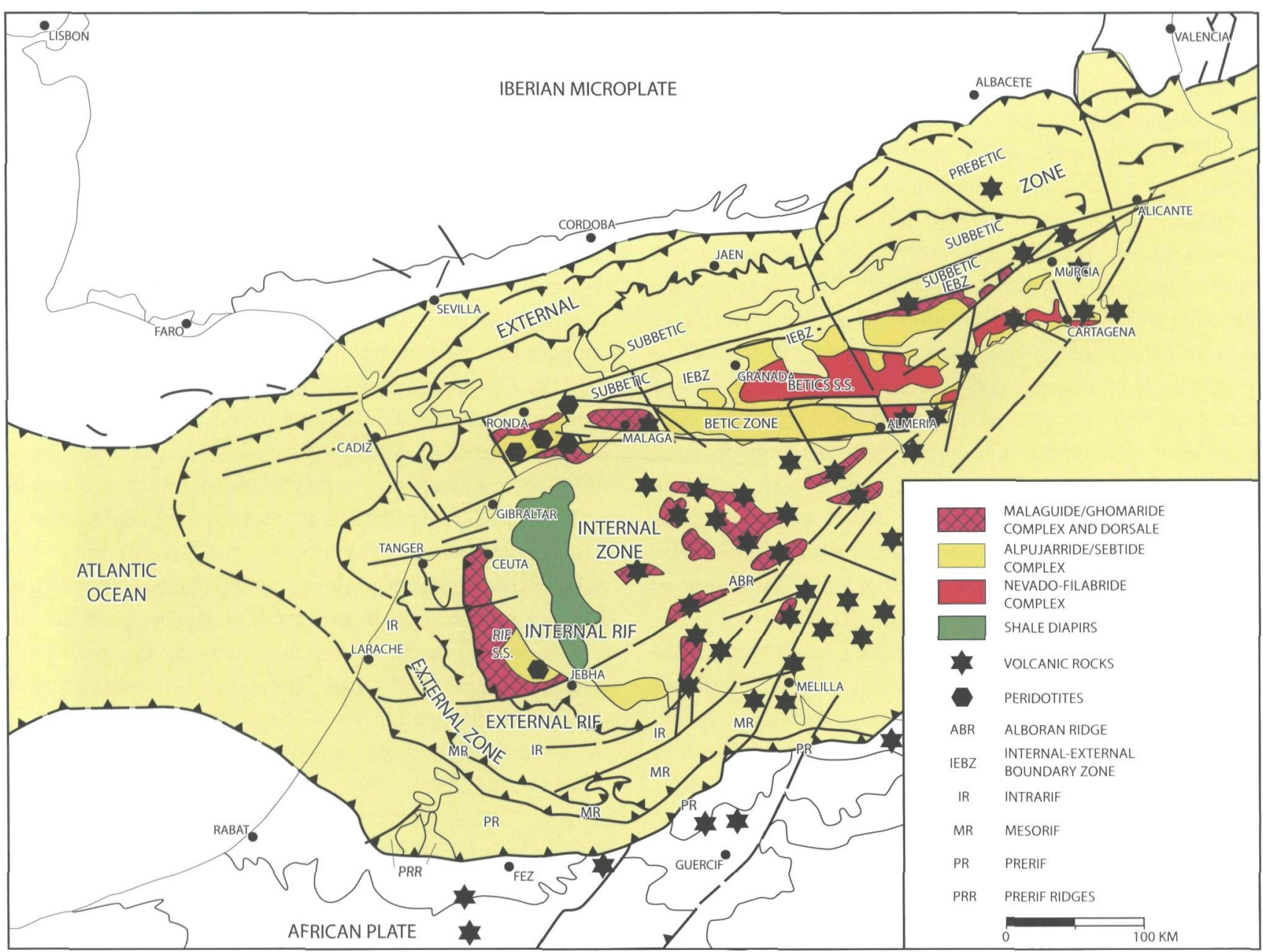

Fig. 2. Structural map of the principal nappe complexes, thrust zones and volcanic areas of the Betic-Rif orocline.

Delga \& Olivier, 1988; Lonergan \& Mange-Rajetsky, 1994). The following units are distinguished (differently named equivalents in northern Morocco between brackets):

1. Nevado-Filabride Complex: comprises Palaeozoic sedimentary rocks affected by polyphase (successively HP/LT and IP/IT) Alpine metamorphism.

2. Alpujarride (Sebtide) Complex: comprises Palaeozoic and Triassic sedimentary rocks affected by polyphase (successively LP/LT, IP/IT and HP/HT) alpine metamorphism (including Ronda (Beni Bousera) peridotites).

3. Malaguide (Ghomaride) Complex: comprises Palaeozoic basement rocks affected by (very low-grade) Variscan metamorphism and non-metamorphic sedimentary cover rocks of Triassic, Jurassic and Tertiary age.

4. Dorsale (Dorsale Calcaire): comprises non-metamorphic limestones, dolomites and marls of Triassic to Early Tertiary age.

5. Predorsale: comprises non-metamorphic flysch, limestones and marls of Jurassic to early Late Tertiary age (transitional between 4 and 6 ).

6. Campo de Gibraltar Flysch (Maghrebian Flysch): comprises non-metamorphic flysch, olistostromes, clays, marls and limestones of Jurassic to Tertiary age.
The first three tectonometamorphic complexes (units 1, 2 and 3) occur dominantly in the Internal Zone (Fig. 2). They formed part of the Late Cretaceous-Early Tertiary mountain system that was fragmented and dispersed westward during the Late Oligocene-Early Miocene extension of the Western Mediterranean (e.g. Sanz de Galdeano, 1990b, 2000; Michard et al., 2002; Rosenbaum \& Lister, 2004). The next two units (4 and 5) crop out locally in the Betics s.s. near the InternalExternal Zone Boundary, that is the irregular leading edge of the onshore part of the Alboran Domain. This Zone Boundary delimits the Internal and External trust zones south of the WSW-ENE trending Cadiz-Alicante Fault Zone (Sanz de Galdeano, 1996a). Together with the Crevillente Fault Zone (Fig.3), the latter tectonic feature is generally interpreted as a dextral strike-slip zone running subparallel to the longitudinal axes of the External Zone and Betic Cordillera in general (Figs 2 and 3; e.g. Hermes, 1978; Sanz de Galdeano, 1983; de Smet, 1984). The Campo de Gibraltar Flysch units are generally considered parts of the Internal Zone because of their predominant structural position in this zone, as $\mathrm{N}$ to NW vergent thrusts (Chalouan et al., 2006a). However, their local occurrence overlying parts of the External Zone, in combination with some 
other characteristics (lack of basement involvement, absent of metamorphic alteration, Miocene deformation), implies that these 'Flysch units' form part of the External Zone (Platt et al., 1995). Alternatively, together with the transitional Predorsale, they merit a separate, albeit cumbersome, classification as 'Flysch Units'. The larger complexes are emplaced on top of each other as the result of NNW directed motion (Sanz de Galdeano, 1997), the uppermost of the N-NW vergent, imbricate thrust stack being referred to as the 'Betic Nappes'. At present, almost all fault contacts both between and within the complexes indicate extensional re-activation. This makes it difficult to reconstruct the kinematics and structural geometries established during previous episodes of extension or compression. The penetrative deformation and metamorphism of the Internal Zone mainly occurred during the Eocene to Early Miocene (Lonergan, 1993). Many of the present tectonic features of the Internal Zone originated during the Late Oligocene-Middle Miocene period. Prior to major compression in the Late Miocene, the Internal Zone experienced episodic extension during the Early and Middle Miocene (García-Dueñas et al., 1992; CrespoBlanc et al., 1994). Overall, the Internal Zone represents an Early Miocene history of persistent, long-distance tectonic transport to the west. When it more or less reached its present position, the 'Alboran Block' collided obliquely with the Betic and Rif marginal realms of the External Zone during the later part of Early Miocene (Platt et al., 1995; Kirker \& Platt, 1998). As a result of this collision, thrusting, strike-slip deformations and vertical-axis rotations of crustal blocks (mostly clockwise in the Betics; anti-clockwise in the Rif) were generated (Frizon de Lamotte et al., 1989; 0sete et al., 1989; Platzman, 1992; Platzmann et al., 1993; Allerton et al., 1993; Calvo et al., 1997; Platzman et al., 2000). This had notable effects on the kinematics of syn-sedimentary faulting and the geometric development of basins, while the Internal-External Zone Boundary contacts obtained their present frontal structurations and positions (Leblanc, 1990; Sanz de Galdeano \& Vera, 1992; Lonergan et al., 1994; Tent-Manclús et al., 2001).

At present, the Mesozoic-Cenozoic rocks of the essentially unmetamorphosed External Zone occur in a thin-skinned foldand-thrust belt affected by diapiric structures of gypsiferous Triassic mudstones (Cater, 1987; de Ruig, 1992). This sedimentary series was originally deposited on the southern continental margin of the Iberian Massif. It was subsequently exhumed (and partly metamorphosed) by the end of the Oligocene (Lonergan, 1993) and propelled north-westward onto the Iberian Foreland by Miocene thin-skinned thrusting with a flat-lying detachments at mid-crustal level (García-Hernández et al., 1980; Banks \& Warburton, 1991). The sedimentary rocks of the External Zone are generally grouped into two continental margin sequences (Fig. 2; Fallot, 1948; Hermes, 1978; García-Hernández et al., 1980):

1. Prebetic Zone: Predominantly composed of platform carbonates and siliciclastic sediments mostly deposited in relatively shallow-marine (near-shore) environments.
2. Subbetic Zone: Predominantly composed of clayey and marly sediments mostly deposited in relatively deepmarine (offshore) environments.

The collision-related deformation of the External Zone (Sanz de Galdeano, 1996a) started abruptly in the relatively basinal zone of the Subbetic. It was initiated after a Late Oligocene-earliest Miocene period of crustal extension (Sanz de Galdeano, 2000), low-angle normal faulting (e.g. Platt \& Vissers, 1989) and crustal thinning (Torné et al., 2000) that strongly affected the Internal Zone contemporaneously with the initial phase of rifting of the Valencia Trough and AlgéroProvençal Basin (Sanz de Galdeano, 1988, 1990a,b, 2000). The effects of the 'post-collision' phase of tectonic deformation, which encompassed large-scale overthrusting during compressional pulses (Crespo-Blanc et al., 1994), propagated externally into the foreland until the Late Miocene, i.e. into the shelfal zone of the Prebetic (Hermes, 1978; Banks \& Warburton, 1991). Compressional tectonics ultimately resulted in the fault-controlled formation of most intra-orogenic basins and mountain ranges in the Late Miocene and, following further (uneven) uplifting after the Miocene, into the development of the Betic thrust-and-fold belt of today (Sanz de Galdeano \& López-Garrido, 1991, 1999; Sanz de Galdeano \& Vera, 1992; Sanz de Galdeano, 2000; Braga et al., 2003). In general, faulting including strike-slip faulting occurred commonly and continuously during the late Cenozoic, resulting in a dense network of countless minor fracture systems and a considerable number of major ones with particular significance for the structural evolution of the Betic Cordillera (Fig. 3; Sanz de Galdeano et al., 1982, 1984, 1995; Sanz de Galdeano, 1983, 1988). Relatively distinct and important fault zones that were active during the Miocene restructuration of the internal area south of the Cadiz-Alicante Fault Zone included the southeasterly Velez Rubio Corridor Fault System (Hermes, 1978, 1984; Geel \& Roep, 1999), Alpujarran Corridor Fault System (Sanz de Galdeano et al., 1985, 1986; Rodríguez-Fernández et al., 1990; Jabaloy et al., 1993; Sanz de Galdeano, 1996a), Gafarillos Fault (Stapel et al., 1996; Huibregtse et al., 1998; Jonk \& Biermann, 2002), Malaga-Almería Fault (cf. Sanz de Galdeano \& Vera, 1992; Sanz de Galdeano et al., 1995), Palomares Fault (Weijermars, 1987; Huibregtse et al., 1998; Jonk \& Biermann, 2002), Carboneras Fault (Boorsma, 1993; Keller et al., 1995; Huibregtse et al., 1998; Faulkner et al., 2003; Pedrera et al., 2006) and Alhama de Murcia Fault (Gauyau et al., 1977; Silva et al., 1992; Martínez-Díaz, 2002). The latter three fault systems are part of the Trans-Alboran Shear Zone (De Larouzière et al., 1988), a major NE-SW trending sinistral strike-slip system that extends into the Maghrebian Domain (Fig. 3).

The principal domains and thrust complexes of the Rif, the southern limb of the orocline, are largely homologous to those of the Betic Cordillera, the northern limb of the strongly curved orogenic sytem (Didon et al., 1973). An Internal Zone 


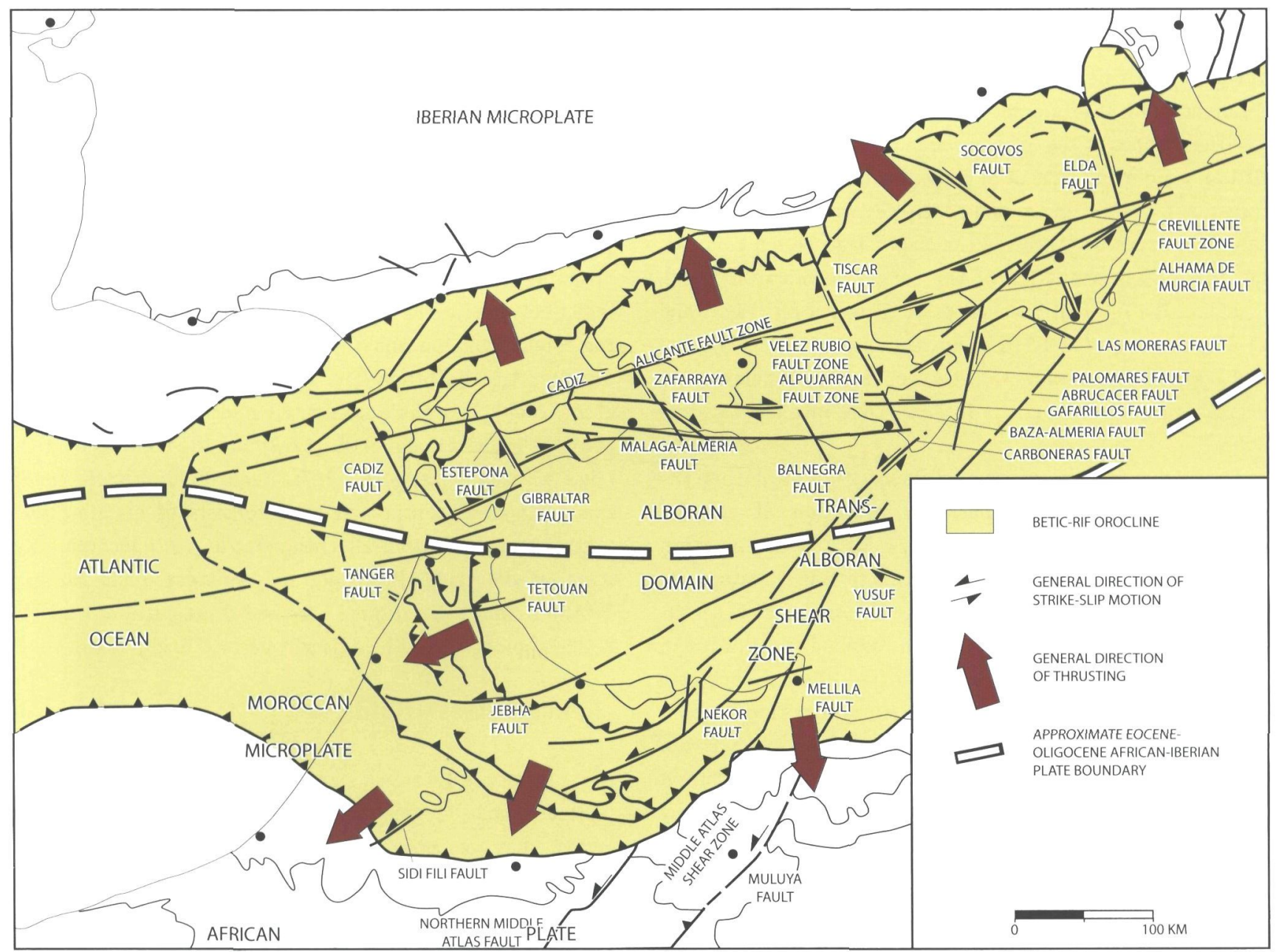

Fig. 3. Location map of the main faults of the Betic-Rif orocline.

and an External Zone are distinguished for each orogenic system. The Rif is further divided into an Internal Rif Domain and an External Rif Domain. These are more or less separated from each other by a zone of Maghrebian 'Flysch Units' including the Predorsale (Piqué, 2001). In contrast with the western Betic Cordillera, these 'Flysch units' overly the External Zone, except for some inliers within the Internal Zone (Didon et al., 1973; Wildi, 1983).

The Internal Rif Domain includes the following main nappe complexes (Fig. 2; Didon et al., 1973; Michard, 1976; Wildi, 1983; Chalouan et al., 2001; Piqué, 2001), each of which having an equivalent in the Betic Cordillera (see above):

1. Sebtide Complex

2. Ghomaride Complex

3. Dorsale Calcaire.

An equivalent of the Betic Nevado-Filabride nappe complex is lacking in the Rif orogenic wedge. The Sebtides include ultramafic mantle bodies (Beni Bousera peridotites) which have been interpreted, like those in the Alpujarrides (Ronda peridotites), to represent a large and thick ultramafic slab that was extensionally fragmented during the formation of the Betic-Rif orocline (Sánchez-Gómez et al., 1995; Zeck, 1997). Their emplacement age is not established with certainty. Both in the Sebtides and the Ghomarides low-angle normal faults (extensional detachments) occur, that dip gently towards the Alboran Sea. They have been related to Middle Miocene rifting of the Alboran Domain (Chalouan et al., 1995). Similar faults have been found in the Betic Zone (e.g. García-Dueñas et al., 1992). The eastern Internal Rif Domain has been affected by 'post-nappe' diapirism involving Triassic evaporites (Leblanc \& Marçais, 1979).

The External Rif Domain is concentrically differentiated into the following main thrust zones (Fig. 2; simplified, partly after Michard, 1976; Leblanc, 1980; Wildi, 1983; Chalouan et al., 2001):

1. Intrarif: characterised by (marginally metamorphic) rock sequences of Mesozoic (Triassic-Cretaceous) and Tertiary age, including Maghrebian Flysch nappes.

2. Mesorif: characterised by rock sequences of Mesozoic (Jurassic-Cretaceous) and Tertiary age.

3. Prerif: characterised by rock sequences of Mesozoic (TriassicCretaceous) and Tertiary age. 
The Rifian External Zone, which represents the Tethyan continental margin of the African Plate, cannot be readily compared with the Betic External Zone. There are significant differences in stratigraphic development. The internal and external nappes of the Rif have been detached from the North African margin and have been propelled from the Early Miocene onwards in overall south- and south-westward directions. The internal nappes overthrusted the Maghrebian Flysch Complex, i.e. the Rif's continuation of the Campo de Gibraltar Flysch Complex. The Internal Rif overlies the External Rif (Figs 1 and 2). Thusting was $W$ and $S$ directed, as indicated by the trend of fold axes and second-order thrusts. The intensity of deformation decreases outwards from the Internal Zone into the External Zone.

Strike-slip faulting played an important role during the structural and tectonosedimentary evolution of the Rif mountain system, especially when the Rif s.s., the southern leading edge of the 'Alboran Block' onshore, was thrusted subhorizontally (together with Maghrebian 'Flysch Units') in southwestern directions onto the Moroccan Foreland (North African continental margin) while the Betic-Rifian Internal Zone as a whole was propelled westward in the Miocene during ongoing $\mathrm{N}$-S convergence of Africa and Iberia (e.g. Rosenbaum \& Lister, 2004). Simultaneously, accommodating movements occurred along the Jebha Fault (Olivier, 1982) and the Nekor Fault (Leblanc, 1980; Asebriy et al., 1993) which, together with e.g. the relatively indistinct Melilla Fault (cf. Sanz de Galdeano, 1988; Sanz de Galdeano \& Vera, 1992), represents the TransAlboran Shear Zone in coastal northwestern Africa (Fig. 3). This shear zone of south-westward escaping tectonic wedges (Chalouan et al., 2006b) can be traced southward across the mainland as a discontinuous, seismically active strike-slip fault system that encompasses the Northern Middle Atlas Fault (Fig. 3) and reaches the Atlantic seaboard near Agadir (Aï Brahim, 1986; Jacobshagen, 1992) from where it can be traced southwestward as far as the Canary Islands. This NE-SW trending, sinistral fault zone borders a triangular African subplate, the so-called Moroccan Microplate, which is delimited in the north by the E-W trending, dextral Azores-Gibraltar Fault Zone. The eastward prolongation of this fault zone comes close to the similarly E-W trending axis of the overthrusted 'Alboran Block' and Betic-Rif collision structure as a whole. In turn this may be linked up to the oceanic spreading centre of the North Algerian Basin (Fig. 3), i.e. the southernmost part of the Algéro-Provençal Basin (cf. Sanz de Galdeano, 2000). The southwestern block margin apparently coincides with a seismic fault zone that trends north-westwards from Agadir on the Moroccan coast to the Azores-Gibraltar Fault Zone offshore (Buforn et al., 1988).

The Betic-Rif orogen is tightly surrounded by an arcuate Betic-Rif foredeep that originated by a downwards bending of the lithosphere in response to Early-Middle Miocene emplacement of nappes that was associated with the westward drifting of the 'Alboran Block'. In southern Spain, north of the Subbetic nappe stacks, a skirting North Betic Foreland Basin originated while in northern Morocco an equivalent Prerif Foreland Basin was formed in front of the Mesorif thrust zone (Figs 1 and 2). West of the Gibraltar Arc proper, which links the Betic and Rif mountain belts, a similar foredeep was formed in response to the collisional westward migration of the 'Alboran Block' (Maldonado et al., 1999; Maldonado \& Nelson, 1999). Structurally, this 'Gibraltar Arc Foreland Basin' is relatively indistinct due to the accompanying tectonic deformation of the foreland region and the chaotic deposition of the huge Gibraltar Arc Allochthon (Fig. 1; Torelli et al., 1997; Medialdea et al., 2004). Like the Guadalquivir Allochthon (Fig. 1; Flinch et al., 1996; Berástegui et al., 1998) and the Prerif Allochthon (Fig. 1; Frizon de Lamotte, 1987; Flinch, 1996; Pratsch, 1996), this tectonosedimentary mélange consists of gravity-driven olistostromes and other allochthonous deposits incorporating strongly deformed Mesozoic and younger rock material detached from their original base and thust outward from the Betic-Rif orogen into the adjacent basin (Flinch, 1996).

\section{General stress fields}

The conspicuously arc-shaped Betic-Rif fold-and-thrust belt represents a geodynamic setting on the peri-Mediterranean orogen that was governed by internal rifting and external thrusting induced by the Alpine convergence of Africa and Iberia. The present day maximum compressional stress in the Ibero-Maghrebian region trends roughly N-S. This fits the general direction of crustal shortening with a rotation pole located near the Canary Islands (Buforn et al., 1988; Argus et al., 1989; Henares et al., 2003). Its present neotectonic configuration and tectonic style has been inherited from widespread Neogene strike-slip and normal faulting, folding and thrusting (Fig. 3) which, in turn, were controlled by compression and extension induced by ongoing relative plate and block motions causing space problems. Convergent plateboundary interaction resulted in a superposition of Alpine deformation phases leading to a complex interference pattern of structures comprising variously-sized, intra-orogen sierras (with heights up to $3500 \mathrm{~m}$ ) and intramontane basins (with mainly (sub)horizontally layered fills) within the diverse Betic-Rif nappe complexes and thrust zones. Onshore, the tectonic development concluded with the exhumation of the Betics s.s. and the Rif s.s.

During the period of late Cretaceous to Cenozoic continental convergence, the tectonic evolution and depositional history of the Betic-Rif plate boundary zone has particularly been affected by far-field stress sources related to the progressive opening of the Atlantic 0cean and the continuing motion of Africa relative to Europe (cf. Dewey et al., 1989; Rosenbaum et al., 2002). In time and space, the orientation and relative importance of the different stress sources, as well as their 
spatial interplay, have changed (Galindo-Zaldívar et al., 1993; Andeweg, 2002). Repetitive changes in the stress field caused repeated reactivation of pre-existing Betic-Rif fault systems, accompanied with the formation of new faults. As a result, a large number of fault-bounded basins evolved under a varying tectonic setting. 0verall, their developmental history records the relative kinematic activity of the African and Iberian lithospheric plates. tectonosedimentary effects registered changes in stress conditions: local, intrabasinal deformation and sedimentation features were responses to episodic modifications of the local, intraplate stress field caused by regional plate reorganizations. In essence, basins record crustal kinematics as these controlled intra-orogen subsidence. The first-order driving forces for the crustal-scale Neogene changes of the stress fields at the Betic-Rif plate-boundary zone were the continuing E directed, Atlantic ridge-push forces. These were generated by the progressive opening of the Atlantic to the west of the Iberian Peninsula (controlled by varying spreading rates) in combination with the African-Iberian collision forces associated with progressive shortening of crust and subduction of lithospheric material (controlled by different motion rates). Reconstructions of Neogene and Quaternary stress trajectories (generally deduced from fault slip data, borehole breakout data, (micro)structures and earthquake focal mechanism solutions) indicate that contemporary stress patterns and directions in southern Spain and northern Morocco were relatively uniform and consistent on a regional scale, albeit with some local variations. Nevertheless, platetectonic processes directed the first-order structural and sedimentary development of the Betic-Rif plate-boundary zone. During periods of tectonic quiescence the second-order eustatic sea-level changes governed the depositional history. Until the earliest Miocene, that is during the time that Iberia was mechanically independent relative to Africa and Europe, the stress patterns were genetically mostly related to the convergence of Africa relative to Europe. During the subsequent (post-Early Aquitanian) period, that is after the definitive mechanical coupling of Iberia and Europe, a predominant kinematic relationship with the convergence of Africa and Iberia prevailed. Through an enhancement in relative motion between both plates large-scale collisional nappe thrusting was triggered which coincided with compressional deformations related to the westward movement of the 'Alboran Block'. Though the trajectories of maximum compressional stress are generally compatible with the plate-motion vector, significant deflections in spatial pattern and direction may develop near large-scale faults (de Ruig, 1990). The following succession of generalized directions of maximum compressional stress and relative plate motion governed the development of the BeticRif cordilleras (compression directions after Morel, 1989; Sanz de Galdeano, 1990b, 1996b; Galindo-Zaldívar et al., 1993; Hlila \& Sanz de Galdeano, 1995; Montenat et al., 1996; Stapel et al., 1996; Keller et al., 1995; Huibregtse et al., 1998; Andeweg,
2002; Gil et al., 2002; Jonk \& Biermann, 2002; Rosenbaum et al., 2002; Ait Brahim et al., 2002; Henares et al., 2003; Zaghloul et al., 2003; Ruano et al., 2006 convergence directions after Dewey et al., 1989; Rosenbaum et al., 2002):

\begin{tabular}{llll}
\hline & $\begin{array}{l}\text { Southern } \\
\text { Spain }\end{array}$ & $\begin{array}{l}\text { Northern } \\
\text { Morocco }\end{array}$ & $\begin{array}{l}\text { Africa-Iberia } \\
\text { Convergence }\end{array}$ \\
\hline Quaternary/Recent & NNW-SSE/NW-SE & NNW-SSE/WNW-ESE & NNW-SSE/NW-SE \\
Late Pliocene & NNW-SSE/N-S & NNW-SSE/NW-SE & NNW-SSE \\
Early Pliocene & NNW-SSE/N-S & NNW-SSE/NW-SE & NNW-SSE/NW-SE \\
Late Miocene & NNW-SSE/NW-SE & NNE-SSW/ENE-WSW & NNW-SSE/N-S \\
Middle Miocene & NNW-SSE/E-W & N-S & NNW-SSE/NNE-SSW \\
Early Miocene & NW-SE & N-S/NE-SW & NNW-SSE/NNE-SSW \\
Late Oligocene & & NNW-SSE/NW-SE & NNW-SSE \\
\hline
\end{tabular}

This overview suggests a predominance of NNW-SSE directions for the Neogene intraplate stress field and plate convergence of the African-Iberian plate-boundary zone. It is emphasized, however, that it is difficult to generalize stress fields for large and geologically complicated areas and over long intervals of time. They are typically regionally heterogenous with local variations in stress over time and with contemporaneous differences in stress condition in neighbouring areas. Periods of compression alternated with periods of extension in the Betic Cordillera (García-Dueñas et al., 1992), Alboran Sea (Chalouan et al., 1997) and Rif (Michard et al., 1996). The compressional stress directions do not necessarily mimic plate motions due to spatial heterogeneities resulting from fault systems. The compressional stress field of northern Morocco rotated anti-clockwise from NNE-SSW/ENE-WSW in the Late Miocene (Tortonian) to NNW-SSE in the Pliocene (cf. Ait Brahim \& Chotin, 1984, 1990; Aït Brahim, 1985; Galindo-Zaldivar et al., 1993), while the orientation of maximum (sub)horizontal compression remained essentially NNW-SSE oriented in Spain. Moreover, it is possible that the stress direction rotated further on a regional scale from NNW-SSE to NW-SE/WNW-ESE in Quaternary time (cf. Ribeiro et al., 1996; Henares et al., 2003). Such a stress field development is consistent with the long-term anti-clockwise rotation of Africa relative to Europe (Dewey et al., 1989; Rosenbaum et al., 2002).

Simultaneous with the collisional migration of the 'Alboran Block' and the complex convergence of Africa relative to Europe, a roughly N-S (commonly ranging between NNW-SSE and NE-SW) trending, thrusting-related direction of crustal extension prevailed in the Alboran Domain from (late) Late Oligocene (González-Lodeiro et al., 1996; Chalouan et al., 1997; Geel \& Roep, 1999; Platt \& Whitehouse, 1999) until Middle Miocene (Langhian) times (Crespo-Blanc et al., 1994; Chalouan et al., 1997; Martínez-Martínez \& Azañón, 1997; Comas et al., 1999; Andeweg, 2002). Consequently, the collisional thickening of the Alboran continental lithosphere (Platt \& Vissers, 1989) occurred before the Late Oligocene onset of lithospheric extension. Most likely, the duration of this stress field 
orientation is kinematically linked to the Chattian opening of the Valencia Trough (Geel et al., 1992; Geel, 1995; Geel \& Roep, 1999) and the Langhian opening of the North Algerian Basin (Mauffret et al., 2004). The coeval occurrence of extension parallel to the regional compression was possibly caused by flexural bending or folding stresses resulting from the large-scale horizontal compression and shortening of the lithosphere. Contemporaneously, compressional NW to SE directed thrusting as well as extensional low-angle normal faulting and thinning of the crust (reducing its strength and making it prone to tectonic reactivation), uplift (possibly related to slab break-off) occurred in the Alboran Domain in association with compressional foredeep development around the entire Betic-Rif orocline (García-Dueñas et al., 1992; Galindo-Zaldivar et al., 1993; Crespo-Blanc et al., 1994). From later Middle Miocene (Serravallian) until early Late Miocene (Tortonian) times, E-W to NE-SW extension was predominant (González-Loreido et al., 1996; Comas et al., 1999; Sanz de Galdeano \& López-Garrido, 2000; Andeweg, 2002; Gil et al., 2002; Gutscher et al., 2002, Martínez-Martínez \& Azañón, 2002). Three principal episodes of extension can be recognized in the Betic Zone: a (late) Chattian-Aquitanian (Biermann, 1995; Geel, 1995), a late Burdigalian-Langhian or Langhian one with a northward (NNW) transport direction (orthogonal to the orogen axis) and a Serravallian one with a (orogen-parallel) southward (WSW) transport (Crespo-Blanc et al., 1994; MartínezMartínez \& Azañón, 1997). These extensions modified older thrust-nappe stacks into units bounded by low-angle normal faults, prior to folding and faulting of these structures by Tortonian and later compressional tectonics (Crespo-Blanc et al., 1994). In the Rif N(N)E-S(S)W extension occurred in the Chattian, N(N)W-S(S)E extension in the Aquitanian and $\mathrm{E}(\mathrm{NE})$ $\mathrm{W}(\mathrm{SW})$ extension in the early Burdigalian (Zaghloul et al., 2003). E-W and NNE-SSW extension occurred successively in the Middle Miocene, after a late Burdigalian period of WSW to SW directed thrusting, whereas roughly E-W extension re-occurred in the chain in the Late Miocene (Chotin \& Ait Brahim, 1988; Hlila \& Sanz de Galdeano, 1995; Andeweg, 2002).

Presently, extension in the Betic Cordillera is NE-SW trending, whereas in northern Morocco NNE-SSW extension occurs (Galindo-Zaldívar et al., 1999; Gil et al., 2002; Henares et al., 2003). For the intermediate, central part of the Alboran Domain, earthquake data provides evidence of NNW-SSE extension (Galindo-Zaldivar et al., 1993), and, most likely, the Alboran Sea is now subjected to NNE-SSW extension (Henares et al., 2003). Overall, the direction of the compressional and extensional stress regimes and their driving plate motions did not change gradually over time, neither locally nor on a regional scale. Rather, they varied and evolved episodically during brief periods of enhanced change in (plate-)tectonic setting, as exemplified by the intra- and terminal Tortonian deformation phases that were first recognized in the Betic Zone (Ott d'Estevou, 1980; Estévez et al., 1982; 0tt d'Estevou
\& Montenat, 1985; see also Boorsma, 1993) and the intraMessinian deformation phase that was originally identified in the External Rif (Kerchaoui \& Morel, 1984; Morel, 1984). The reality of such punctuated tectonics separating periods of relative tectonic stasis for the entire Neogene will be argued in the following sequence stratigraphic analysis of Betic-Rif basins.

\section{General origin of basins}

Within the Betic-Rif plate-boundary zone a great diversity of basins developed in a close causal relationhip with local tectonic circumstances and regional stress regimes. Several developed on an open synform reflecting crustal compression and shortening by the collision of Africa and Iberia. Numerous basins of the Betic and Rifian Internal Zones are complex intramontane (half-) grabens and pull-apart basins, which remained tectonically active since their initial development and filling with sediments (see below). Their origin often involved an extensional, strike-slip or thrust-top mechanism of subsidence. Foreland basins are limited to the compressional External Zones and adjoining foreland regions. With respect to the time of origin relative to the emplacement of the 'Alboran Block', Betic-Rif basins can be grouped as follows (Fig. 4; based on Sanz de Galdeano, 1991):

1. Early Neogene Basins: Basins that formed during the Late Oligocene to Middle Miocene period of main rifting and which were already extant during the Early and Middle Miocene period of westward (ENE to WSW) movement of the 'Alboran Block'. In particular, the basins in the Alboran Domain were tectonically unstable by virtue of having a mobile substratum. Deposition occurred contemporaneously with the westward movement of the sole thrust of the 'Alboran Block'. As 'piggy-back' basins developed on the hanging-wall of a crustal thrust (Jabaloy et al., 1992), they were tectonically and stratigraphically disconnected from basins comprising older strata. These 'piggy-back' basins were severely deformed and faulted by both synsedimentary tectonics and later tectonics. Consequently, the preserved remnants (generally as small and scattered outcrops) do not allow of the detailed reconstruction of their geometric features and sedimentary fills, or for that matter their precise typological classification. In the Betic Internal Zone the scattered, allochthonous syn-rift strata of the Alozaina-Tolox region (northwest of Malaga; unconformably overlying the Malaguide nappes) and the La Viñuela-Majiaza region (northeast of Malaga; unconformably overlying the Alpujarride nappes) are particularly representative for this kind of deformed basin (DurandDelga et al., 1993; Sanz de Galdeano et al., 1993). Examples are the pre-Late Miocene fills of the Granada, Guadix-Baza, Sorbas-Tabernas and Ugijar Basins (Fig. 4; Jabaloy et al., 1992). In the South Iberian Domain the External Zone 


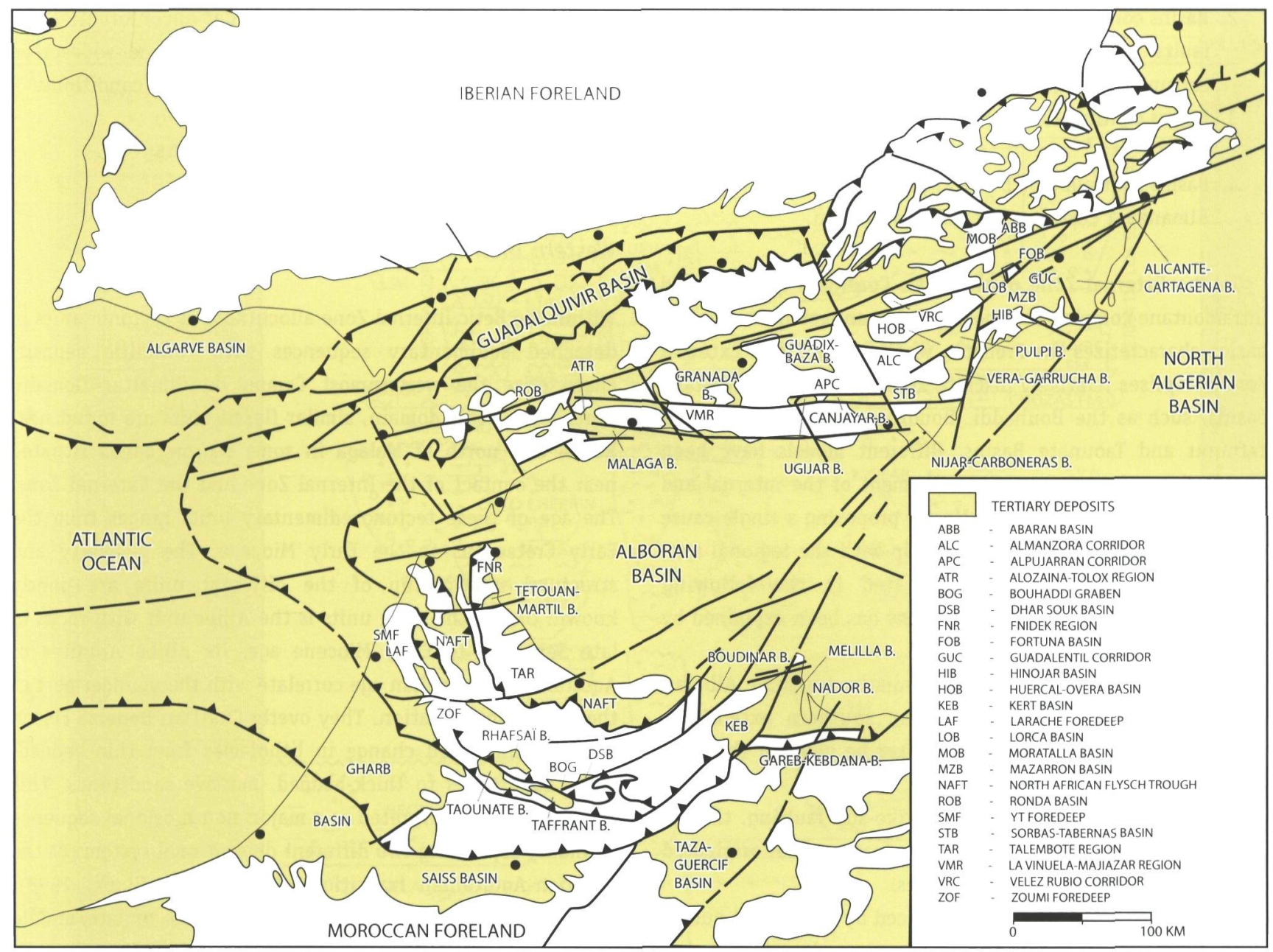

Fig. 4. Location map of the main basins of the Betic-Rif orocline.

includes the compressional Proto-Guadalquivir foreland basin, to which the Moratalla Basin belongs, and, partly, the North African Flysch Trough. In the Maghrebian Domain occur the Western Prerif Foreland Basin, which in front of thrust fronts includes small flexural basins, such as the Larache and Zoumi Foredeeps, and distally the Gharb and Saiss Basins, and the complex Eastern Prerif Foreland Basin, which comprises the Gareb-Kebdana and Taza-Guercif Basins (Fig. 4). The Internal Zones mostly consist of the Alboran Basin, the thrust-belt hinterland basin that collapsed at the centre of the Alboran Domain due to back-arc stretching of the basement. Along the thrust front of the Betic Internal Zone foreland sediment accumulation occurred in a piggyback basin setting (Roldán \& Rodríguez-Fernández, 1991; Lonergan \& Mange-Rajetzky, 1994). In the Internal Rif and adjoining External Rif correlative Late Oligocene to Early Miocene marine deposition is recorded in the allochthonous Dorsale Calcaire, Predorsale and Numidian Flysch units, and in the autochthonous remains of the Tetouan-Martil Basin that overly Ghomaride nappes (Feinberg et al., 1990; Benmakhlouf \& Chalouan, 1995, Ouazani-Touhami \& Chalouan, 1995; Chalouan et al., 2001).
2. Late Neogene Basins: Basins that formed after the Middle Miocene when the westward motion of the 'Alboran Block' had virtually come to an end. In the Betic Zone this includes many intramontane basins, such as the Abaran, Fortuna, Granada, Guadix-Baza Basin, Lorca, Malaga, NijasCarboneras, Ronda, Sorbas-Tabernas and Vera-Garrucha Basins (Fig. 4). The geometries and stratigraphic architectures of these basins were generally controlled by re-arrangements of fault blocks, which were determined by syn-sedimentary tectonic movements within a network of strike-slip faults. The resultant structures and sedimentary basin fills reflect a complex tectonic and depositional history encompassing relative sea-level fluctuations represented by unconformities. The time gaps represented by these unconformities have rarely been assessed accurately and precisely. These basins can be divided into four types based on the predominant type of synsedimentary control by faults (Fig. 4; after Sanz de Galdeano \& Vera, 1992):

1. Basins controlled by NE-SW to NNE-SSW trending sinistral strike-slip faults: Hinojar Basin, Lorca Basin (partly), Pulpi Basin, Vera-Garrucha Basin (partly). 
2. Basins controlled by NW-SE and NNE-SSW trending normal faults (mainly): Granada Basin, Guadix-Baza Basin, Fortuna Basin (partly), Lorca Basin (partly), Ronda Basin.

3. Basins controlled by N-S trending normal faults: Mazarron Basin.

4. Basins controlled by E-W trending normal faults (mainly): Almanzora Corridor, Huercal-0vera Basin.

In the External Zone of the Betic Cordillera a widespread intramontane complex of generally interconnected continental basins characterizes the Prebetic, whereas the Rifian External Zone comprises relatively discrete and localized intramontane basins, such as the Bouhaddi, Boudinar, Dhar Souk, Melilla, Tafrannt and Taounate Basins. Different models have been proposed for the origin and development of the internal and external intramontane basins. Mostly proposing a single-cause rather than a multi-cause relationship with the regional synsedimentary kinematics. As indicated in the following sections, the formation of these basins has been explained by subsidence mechanisms such as:

1. NE-SW extension within the similarly trending Alboran Shear Zone and its northern and southern extensions, though the fault system proper may be younger than the basin.

2. E-W extension associated with strike-slip faulting, though the bounding faults tend to be later features that originated by re-activation of older structures.

3. NNE-SSW to NW-SE extension induced by arc-normal pull of the E-NE trending slab attached to the subducted Iberian Plate and associated with the NE-SW progressing detachment of the slab beneath the Betics.

4. N-S extension due to the collapse of the continental crust induced by convective removal or delamination of thickened sub-continental lithosphere.

Like the flexural (Proto-)Guadalquivir, Gharb, Saiss and Gareb-Kebdana foreland basins, the fault-bounded Betic-Rif basins are the product of kinematic activity during phases of tectonic stress and deformation that, in turn, were driven by the geodynamics of the Africa-Iberia plate convergence. Continuously evolving tectonic conditions, which largely masked the effects of eustatic sea-level fluctuations, were the main control on the sedimentary development of the basins. Deposition occurred in a complex, continuously changing tectonopalaeogeographic setting including a network of interconnected depressions and emergent highs. Together, these constituted a temporary 'basin-and-range' topographic manifestation of the Africa-Iberia collision. Climatic change was a minor control on the sediment accumulation in the depocentres and on the erosion of the land masses. As argued in the following review, deposition and non-deposition/ erosion occurred episodically under strong tectonic control. This resulted in the overall syn-tectonic sedimentary sequences being delimited by correlative, first-order unconformities and non-erosional boundaries which mark brief and widespread periods of simultaneous change in depositional conditions.

\section{Tectonostratigraphy of Betic Basins (Figs 4 - 6; Appendices 1 - 7)}

\section{Western Internal Betic Basins (Fig. 5)}

Within the Betic Internal Zone allochthonous tectonic units of detached sedimentary sequences with turbiditic deposits characterize the westernmost Campo de Gibraltar Domain. Northeast of this domain, similar flysch units are found near Ronda and north of Malaga in some narrow bands situated near the contact of the Internal Zone and the External Zone. The age of these tectonosedimentary units ranges from the Early Cretaceous to the Early Miocene. The geometry and structural relationship of the different units are poorly known. One of the main units is the Aljibe unit with rocks of late Senonian to Early Miocene age. Its Aljibe Arenites of Aquitanian-Burdigalian age correlate with the younger part of the Numidian Formation. They overly Chattian Beneiza Flysch with a pronounced change in lithofacies from thin-bedded, marly sandstones to thick-bedded, massive sandstones. This contact that is interpreted as a major, non-erosional sequence boundary separating two different depositional systems at the Chattian-Aquitanian transition (Stromberg \& Bluck, 1998). The upper part of the Aljibe flysch consists of late/middle Burdigalian sandstones and siltstones referred to as the Neonumidian Formation (López-Garrido \& Sanz de Galdeano, 1999). Like the Maghrebian flysch, its Rif-Tell equivalent, the Campo de Gibraltar flysch originated in a deep basin, the North African Flysch Trough (Appendix 1). This basin fringed the frontal parts of the hanging-wall 'Alboran Block' during its initial westward migration. By the late Burdigalian, the flysch trough started to collapse and close due to the collision of the newly formed accretionary wedge (i.e. the migratory foot-wall fold-and-thrust belt at the western Betic front of the westvergent Gibraltar Thrust) with the South Iberian palaeomargin located at the present site of the Betic External Zone. The destruction of the flysch trough was accompanied by the tectonogravitational emplacement of the Neonumidian Formation and succeeded by post-collisional backthrusting of the flysch complex at the end of the Burdigalian (Guerrera et al., 1993).

The Late Oligocene and Early Miocene Campo de Gibraltar and Maghrebian flysch units are correlative with a lithologically diverse group of marine, partially olistostromic and turbiditic formations (Sanz de Galdeano \& Vera, 1992; Sanz de Galdeano et al., 1993), which formed an areally irregular sedimentary 'cover' on thrusted basement rocks of the Betic Internal Zone (Balanyá \& García-Dueñas, 1987; González-Lodeiro et al., 1996). The unconformable superposition of these strata on top of 


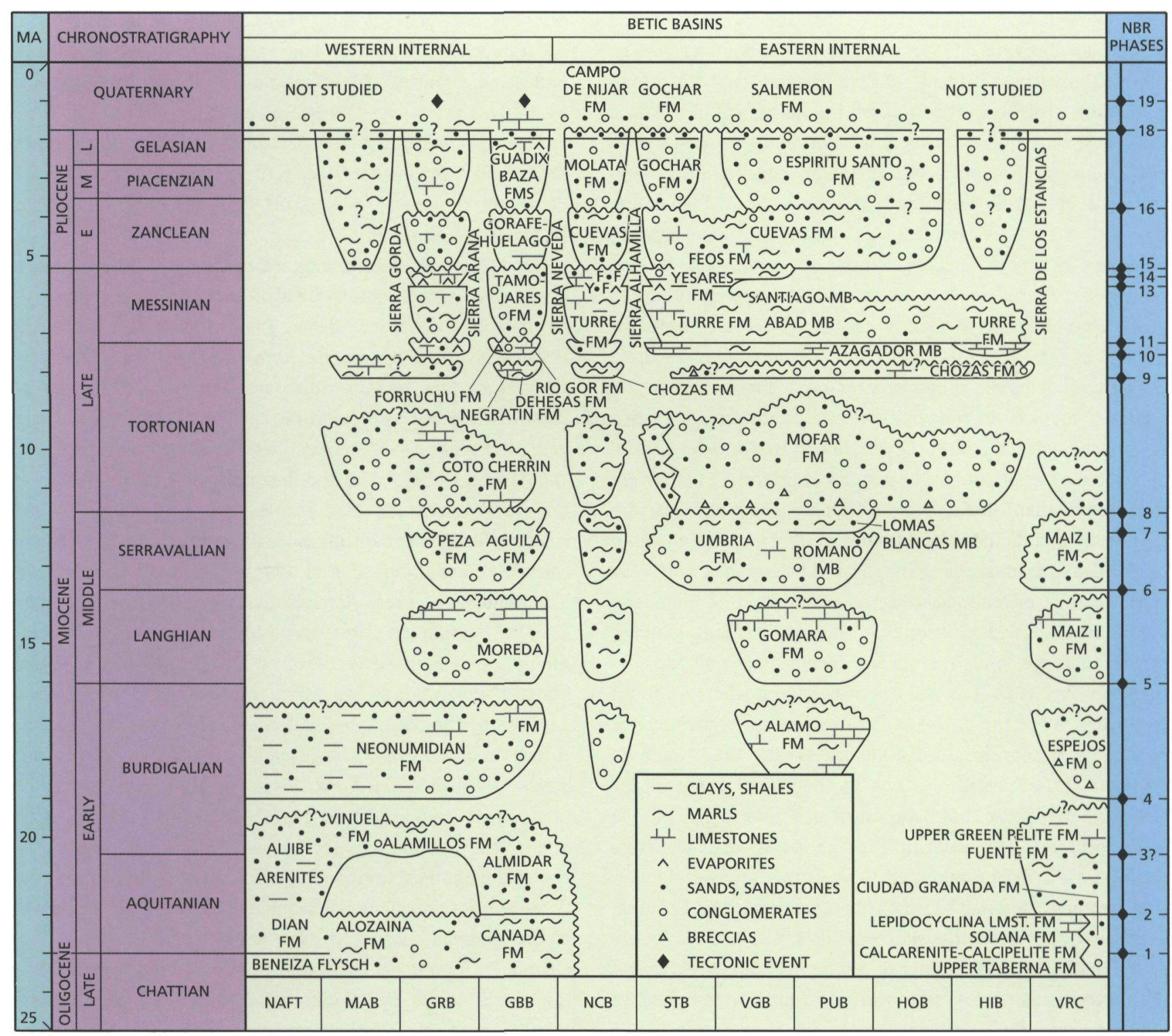

Fig. 5. Sequence stratigraphic diagram for western and eastern internal basins of the Betic Cordillera. GBB: Guadix-Baza Basin, GRB: Granada Basin, HIB: Hinojar Basin, HOB: Huercal- Overa Basin, MAB: Malaga Basin, NAFT: North African Flysch Trough, NCB: Nijar-Carboneras Basin, STB: SorbasTabernas Basin, PUB: Pulpi Basin, VGB: Vera-Garaccha Basin, VRC: Velez Rubio Basin.

Malaguide and Alpujarride nappe complexes indicates that the major thrusting occurred before the (late) Chattian.

Beneath the Malaga Basin, a depocentre of post-Serravallian age, the 'cover' comprises the Alozaina Formation, a terminal Chattian to early Aquitanian sequence of shallow-marine sands and conglomerates that was deposited prior to the westward displacement of the 'Alboran Block', and deposition of the mainly deeper-marine Viñuela Formation. Following the 'Aquitanian Paroxysm' (Guerrera et al., 1993), these clastics were unconformably transgressed by early/middle Burdigalian breccias ('Las Millanas Fm.'), conglomerates and mudstones which accumulated coevally with syn-rift migration of the 'Alboran Block' (Durand-Delga et al., 1993; Sanz de Galdeano et al., 1993; López-Garrido \& Sanz de Galdeano, 1999). The Viñuela Formation is unconformably covered by the Neonumidian
Formation in succession to a erosional episode related to late Burdigalian overthrusting. The thrusting occurred simultaneously with a NW directed mass sliding events of which the resulting sedimentary sequence is known as the 'Alozaina Complex' (Balanyá \& García-Dueñas, 1987). This tectonic mélange consists of olistostromes derived from the Dorsale, Predorsale and Campo de Gibraltar Flysch nappe complexes (González-Lodeiro et al., 1996) during the obliteration of the North African Flysch Trough. This start of the 'Burdigalian Paroxysm' (Guerrera et al., 1993) may be attributed to a change in the convergence of Africa and Iberia that climaxed with abrupt accretion of the 'Alboran Block' to the South Iberian plate margin (Sanz de Galdeano \& López-Garrido, 1991). Langhian and Serravallian deposits are absent in the Malaga region, assumedly due to widespread tectonic uplift 
that commenced at the end of the Burdigalian (López-Garrido \& Sanz de Galdeano, 1999; see also Guerrera et al., 1993). Deposition was resumed at the Serravallian-Tortonian transition with the formation of the intramontane Malaga Basin as a consequence of tectonic subsidence induced by NESW extension. The preserved Tortonian consists of a lower sequence of marine sands and conglomerates and an upper one with marine calcarenites and marls. The sequences are bounded by unconformities. Messinian strata are lacking (López-Garrido \& Sanz de Galdeano, 1999), supposedly due to erosion/non-deposition mainly caused by tectonic uplift at the end of the Miocene. The Pliocene is composed of abruptly transgressing basal conglomerates and marls which are gradually replaced in time by regressive sands (López-Garrido \& Sanz de Galdeano, 1999). Deposition occurred under control of an active system of basin-bounding faults in a shallow sea with islands (Sanz de Galdeano \& López-Garrido, 1991; LópezGarrido \& Sanz de Galdeano, 1999).

The Granada Basin is a complicated half-graben northeast of the Malaga Basin at the Internal-External Zone Boundary. It originated after deposition of a sequence of Aquitanian? to Serravallian age, which sequence includes several tectonosedimentary breaks from the top of the Burdigalian Alamillos Formation to the top of the La Peza Formation (Martín Suarez et al., 1993; see also Martín-Algarra et al., 1988; Sanz de Galdeano \& Vera, 1992). As one of the larger intramontane basins of the Betic Cordillera, the basin took shape in the early Tortonian. Its initial infilling coincided with a marine transgression that onlapped a continental relief that was strongly modified during the compressional 'Terminal Serravallian' tectonic phase (Estévez et al., 1984). The newly formed basin subsided rapidly in response to NE-SW extension (Reicherter, 1999). Six unconformity-bounded sedimentary sequences are distinguished (Fernández et al., 1996). The accumulation of the basal sequence of clastics and bioclastic carbonates was terminated by a compressional intra-Tortonian tectonic event (Estévez et al., 1982). This event marks the commencement of overall regressive deposition of (reefal) carbonates, marls, sands and conglomerates (Sanz de Galdeano, 1988; García García et al., 1999). During the late Tortonian, the basin acquired its present-day configuration. The correlative strata are unconformably succeeded by a terminal Tortonian sequence representing continentalisation of the basin. The marine-continental sequence comprises, amongst others, selenitic gypsum and halite (Dabrio et al., 1982) which correlate with the evaporitic horizons of the eastern Betics assigned to the 'Tortonian Salinity Crisis' (Krijgsman et al., 2000; see below). It is unconformably overlain by a Messinian sequence comprising typically a lower, marly and calcareous subsequence and an upper subsequence with evaporites, marls, sands and (finally) lacustrine limestones. Deposition of this sequence began around the Tortonian-Messinian transition when the Sierras Gorda and Arana and the southerly Sierras Tejeda and
Almijara emerged abruptly, thus suddenly enhancing the geographical isolation of the basin (Dabrio et al., 1982). Reflecting a continued land-locked setting, the Granada basin fill evolved into a two-fold Plio-Pleistocene sedimentary series of lacustrine and fluvial deposits including carbonates, marls, sands and conglomerates as well as lignites (Fernández \& Rodríguez-Fernández, 1991; Sanz de Galdeano \& Vera, 1992; Fernández et al., 1996).

The structural position and tectonostratigraphic architecture of the nearby intramontane Guadix-Baza Basin are comparable to those of the Granada Basin. The pre-Neogene basement is likewise overlain by marine formations of latest Chattian/ early Aquitanian to Serravallian age (García Aquilar \& Martín, 2000). In the bounding Sierra Arana-Mencal region (northern part of the basin) the sequential development evidences the 'Aquitanian Paroxysm' by the unconformable superposition of the early Aquitanian (and older) Canada Formation by the similarly deep-marine Almidar Formation of late Aquitanianearly Burdigalian age (Soria, 1994). This event signifies the initiation of the Proto-North Betic Foreland Basin (Appendix 2). The 'Burdigalian Paroxysm', which marks the collision of Alboran and Iberia, is recorded by an unconformable contact between the Almidar Formation (corresponding to the final deposits of the South Iberian palaeomargin) and the Moreda Formation of late Burdigalian-Langhian age. This major tectonic phase established the North Betic Foreland Basin proper by pronounced loading of Betic thrust masses (Sanz de Galdeano \& Vera, 1992). Important tectonic events occurred later at the end of the Burdigalian (dividing ultimately the Moreda Fm. into two unconformity-bounded sequences) and at the conclusion of the Langhian (marked by the erosional upper limit of the Moreda Fm.) and the Serravallian (defined by a hiatus at the top of the Aguila Fm.; Soria, 1994, 1998). The Late Miocene and Pliocene fill of the intramontane Guadix-Baza Basin includes an unconformable series of six tectonosedimentary sequences which closely correlate with those of the Granada Basin (Fernández et al., 1996; Soria et al., 1998). The sequence boundaries represent tectonic events corresponding to changes in the stress field (Soria, 1994) accompanied by brief periods of fracturing and folding (Soria et al., 1998, 1999). Tortonian deposition is represented by two unconformably superposed sequences, the Coto Cherrin Formation and the approximately coeval Dehesas and Negratin Formations (sequence I of Soria et al., 1999) of overall transgressiveregressive marine carbonates, marls and clastics (Fernández et al, 1996; Soria et al., 1999). The younger Miocene strata include the marine-continental Forruchu and Rio Gor Formations (sequence II of Soria et al., 1999) of latest Tortonian age and a latest Tortonian?/Messinian sequence of alluvial conglomerates and sands and lacustrine marls representing the Tamojares Formation (sequence III of Soria et al., 1999; sequence I of García Aguilar \& Martín, 2000). The latter is unconformably succeeded by the freshwater marls and 
carbonates of the Early Pliocene Gorafe-Huelago Formation (sequence II of García Aguilar \& Martín, 2000). In turn, these lacustrine deposits are unconformably overlain by the Guadix and Baza Formations, a Plio-Pleistocene sequence consisting of alluvial clastics and lacustrine evaporites and carbonates (sequence III of García Aguilar \& Martín, 2000). The apparently isochronous and conformable contact between the evaporites and the overlying carbonates of this succession is tentatively interpreted to be a sequence boundary event straddling the Pliocene-Pleistocene transition. Deposition of these nonmarine strata in the overall NE-SW aligned depression was related to NE-SW extension that incorporated dextral strikeslip movement along the similarly striking Negratin Fault, which is part of the dextral Cadiz-Alicante Fault Zone.

\section{Eastern Internal Betic Basins (Figs 5 and 6)}

Southeast of the Guadix-Baza depocentre, the marine NijarCarboneras Basin north of the volcanic Sierra de Gata communicated with the Mediterranean via the Agua Amarga, Saltador and Feos corridors. The sedimentary succession of this NE-SW elongated, extensional basin comprises sequences ranging in age from middle/late Burdigalian to Piacenzian/ Gelasian (Montenat et al., 1990a; Van de Poel, 1994; Keller et al., 1995; Huibregtse et al., 1998). Localized tuff horizons interbedded with calcareous mudstone and deposited unconformably on the basement are attributed to volcanism at Cabo de Gata that began in the late Aquitanian (Scotney et al., 2000). The onset of this volcanic activity ( $21 \mathrm{Ma})$ succeeded

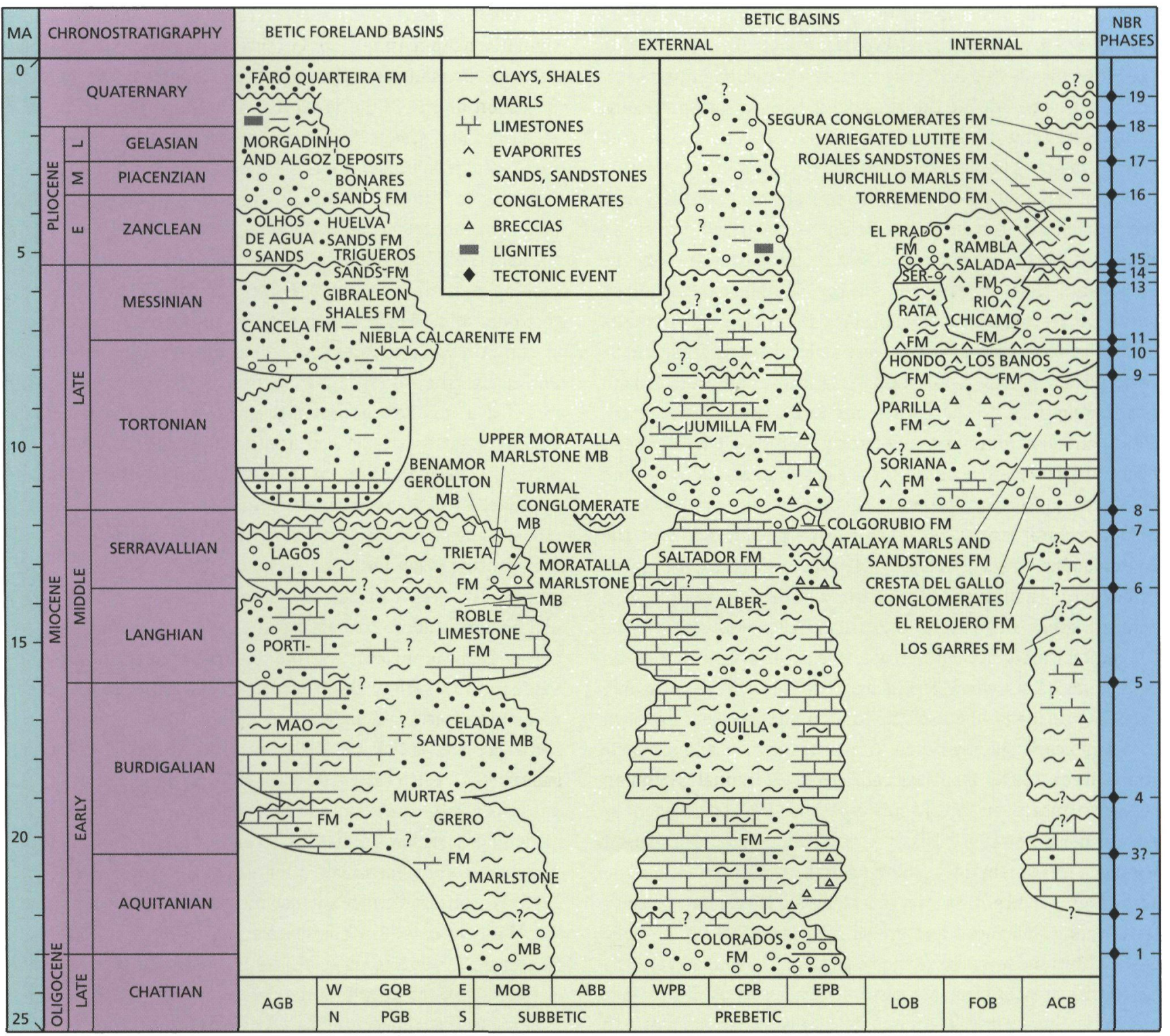

Fig. 6. Sequence stratigraphic diagram for eastern internal, external and foreland basins of the Betic Cordillera. ABB: Abaran Basin, ACB: AlicanteCartagena Basin, AGB: Algarve Basin, FOB: Fortuna Basin, GQB: Guadalquivir Basin, LOB: Lorca Basin, MOB: Moratalla Basin, PGB: Proto-Guadalquivir Basin, CPB: Central Prebetic, EPB: Eastern Prebetic, WPB: Western Prebetic. 
pronounced heating ( 23 - 21 Ma) and uplift that was followed by rapid cooling of Alpujarride basement rocks and unroofing of the initial Betic orogen through extensional collapse (Scotney et al., 2000; Platt et al., 2003). The 'Saltador Formation' of middle/late Burdigalian to Tortonian age (Huibregtse et al., 1998) includes an unconformable basal conglomerate that marks the approximate beginning of movement on the Carboneras Fault ( $18 \mathrm{Ma}$; Scotney et al., 2000). The conglomerate is overlain by deep-marine marls and turbiditic siltsandstones. Non-angular unconformities recording tectonic activity at the Carboneras Fault (Keller et al., 1995) developed at the Burdigalian-Langhian and Langhian-Serravallian transitions (Keller et al., 1995). Later on, angular unconformities that record phases of tectonic uplift and erosion/nondeposition developed near the Serravallian-Tortonian transition, in late Tortonian time and around the Tortonian-Messinian transition, that is at the top of the basal Azagador Member of the latest Tortonian to middle Messinian Turre Formation (Keller et al., 1995). All these unconformities record tectonic activity at the NE-SW trending, left-lateral transpressional Carboneras Fault (Pedrera et al., 2006) that accommodated African-Iberian plate convergence by strike-slip in combination with syn-tectonic subsidence and deposition. Volcanism near the Serravallian-Tortonian transition ( $11 \mathrm{Ma}$; Scotney et al., 2000) seems to signify the cessation of movement on the Carboneras Fault at the end of the 'Terminal Serravallian' phase of tectonic compression. At the Tortonian-Messinian transition the compressional stess field changed from NW-SE striking to virtually N-S striking, marking the onset of main tectonic activity at the Carboneras Fault (Huibregtse et al., 1998). The unconformably and mostly isochronously deposited Azagador Member consists of calcareous sandstones and calcarenites in the northerly Nijar Subbasin. These grade abruptly upwards into the deep-marine pelagic marls of the Abad Member, the upper part of the Turre Formation (Van de Poel, 1994). Their deposition occurred during a major phase of strike-slip faulting that is most strikingly expressed in the Carboneras Subbasin by the volcaniclastic Brèche Rouge de Carboneras (Krautworst \& Brachert, 2003). The conformably overlying Abad marl beds of the Nijar Subbasin were laid down in an increasingly restricted, shoaling marine environment (Van de Poel, 1994). They are conformably (Fortuin \& Krijgsman, 2003) or unconformably (Aguirre et al., 2004) succeeded by the Yesares Formation. This is a major regressive, desiccation sequence of dominantly thick-bedded and massive marine evaporites representing the spectacular Messinian Salinity Crisis that commenced and ended synchronously throughout the Mediterranean realm (Krijgsman et al., 1999a, 2001). The evaporites are conformably overlain by the Feos Formation, the Betic representative in the Mediterranean realm of the overall oligohaline Lago Mare facies of the terminal Messinian (Fortuin \& Krijgsman, 2003; Aguirre et al., 2004). Following the development of an angular unconformity (Keller et al.,
1995), diastem (Fortuin et al., 1995) or razor-sharp conformity (Fortuin \& Krijgsman, 2003) at the Messinian-Zanclean transition, marls and sandstones of the Cuevas Formation (Pliocene I of Montenat et al., 1990a; lower Cuevas Fm. cf. Huibregtse et al., 1998) accumulated during the Early Pliocene. In turn, this sequence is overlain by the Molata Formation (Pliocene II of Montenat et al., 1990a; upper Cuevas Fm. cf. Huibregtse et al., 1998; Van de Poel, 1994), a sequence of continental and shallow-marine sandstones and conglomerates with an angular unconformity at its base and another unconformity marking the Pliocene-Pleistocene transition at the base of the Campo de Nijar Formation (Keller et al., 1995).

The sierras bounding the Nijar-Carboneras Basin in the north are separated from each other by the NW-SE trending Rioja Corridor in the west and the N-S trending Polopos Corridor in the east. Both corridors were marine passages (prior to evolving into the present-day transpressional sills) through which the Nijar-Carboneras Basin communicated with the SorbasTabernas Basin to the north (Ott d'Estevou, 1980; Ott d'Estevou \& Montenat, 1990). The Sorbas-Tabernas-Basin is an E-W elongated depression located on an open synform. In the west, the basin was linked to the Nijar-Carboneras Basin by the Tabernas and Rioja corridors. In the east, the Sorbas-Tabernas Basin communicated with the Vera-Garrucha Basin (see below) through the NE-SW trending Los Gallardos Corridor. Its structural development and subsidence was controlled by strike-slip tectonics and normal faulting along the Gafarillos Fault, one of the principal, more or less N-S oriented fault zones of the Betics s.s. The stratigraphic record of this pull-apart basin includes a number of proximal unconformities which grade distally into (apparent) conformities. Deposition commenced with the accumulation of a continental sequence of red conglomerates, which is, either conformably or unconformably, replaced by a sequence of conglomerates, sands and marls representing a marine flooding of the basin. Sequence stratigraphically, these initial strata are assigned to the early/ middle Serravallian Romana Member and the late Serravallian Lomas Blancas Member of the Umbria Formation (Sanz de Galdeano \& Vera, 1992; Braga \& Martín, 1996). They accumulated until the 'Terminal Serravallian' tectonic phase (0tt d'Estevou, 1980; 0tt d'Estevou \& Montenat, 1990) under influence of E-W compression (Jonk \& Biermann, 2002). The unconformably overlying alluvial to deep-marine siliciclastics belonging to Mofar Formation of early/middle Tortonian age (Rondeel, 1965; Tortonian 1 of 0tt d'Estevou \& Montenat, $1990)$ is truncated by an angular intra-Tortonian unconformity (0tt d'Estevou, 1980; Weijermars et al., 1985; 0tt d'Estevou \& Montenat, 1990; Stapel et al., 1996). Subsequent deposition of the shallow to deep-marine Chozas Formation (Tortonian 2 of Ott d'Estevou \& Montenat, 1990) continued in a sinistraloblique strike-slip setting with NW-SE compression (Jonk \& Biermann, 2002) until a phase of prominent tectonic compression and stratal distortion of latest Tortonian age (0tt 
d'Estevou, 1980; 0tt d'Estevou \& Montenat, 1990). The latter event comprised inversion and emergence of the basin, causing widespread and severe erosion of the basin fill. The Chozas Formation is thus typically truncated by a major angular unconformity. The hiatus developed contemporaneously with a sinistral to dextral strike-slip reversal at the E-W trending Gafarillos fault zone (Haughton, 2001). The Chozas Formation is overlain by a final Tortonian sequence of early Turre deposits (Azagador Mb.; Braga \& Martín, 1996). Deposition of this sequence was coeval with a rotation of the axis of tectonic compression from NW-SE to NNW-SSE (Weijermars et al., 1985; Stapel et al., 1996; Huibregtse et al., 1998; Braga et al., 2003). The change in stress field induced additional compression and inversion of the basin. Inversion ended near the Tortonian-Messinian transition with the establishment of N-S compression (Stapel et al., 1996; Haughton, 2001; Jonk \& Biermann, 2002). The dominantly marine facies of the Turre sequence persisted without interruption into the Messinian Abad Member under the combined influence of tectonics and eustacy (Martín \& Braga, 1996). Following shallowing, reduction in size and finally falling dry of the basin during the Messinian Salinity Crisis, Messinian sedimentation proceeded successively with the (locally) unconformable (Riding et al., 1999) or (essentially) conformable (Fortuin \& Krijgsman, 2003) accumulation of the Yesares evaporites and the conformable deposition of the post-evaporitic Lago Mare clastics of the marine Sorbas Member (5.67-5.60/5.54 Ma; Krijgsman et al., 2001) and the unconformably overlying alluvial-lacustrine Zorreras Member (5.52-5.33 Ma; Krijgsman et al., 2001; excluding uppermost marine strata of Pliocene age; see also Aguirre et al., 2004) of the terminal Messinian Feos Formation, like in the NijarCarboneras Basin. Thus, marine deposition prevailed following post-evaporitic re-flooding of the Mediterranean until the commencement of basin-wide desiccation and continentalisation (5.6 - 5.5 Ma) of the main Messinian event. The intra-Lago Mare crisis was initiated by a major drop in sea level in the Mediterranean Basin due to isolation from the Atlantic. This event is also recorded by a stratigraphic hiatus in the NijarCarboneras Basin (Fortuin \& Krijgsman, 2003; absent according to Aguirre et al., 2004). Marine deposition resumed in the Zanclean with the transgressive accumulation of the mainly fluvio-marine Cuevas Formation (or Abrioja Fm.) on top of an angular unconformity (Riding et al., 1999). Accumulation of the fluvial unconformable, lower part of the Gochar Formation occurred until the occurrence of another break in sedimentation near the Pliocene-Pleistocene transition following which the upper Gochar Formation (or Gador Fm.) was laid down.

Compression controlled the structural configuration and the principal sequence stratigraphic architecture of the VeraGarrucha Basin, particularly under influence of syn-sedimentary deformation induced by lateral displacement along the NNE-SSW striking Palomares strike-slip fault zone, which largely took up overall N-S compression of the Eastern Betic Shear Zone along the eastern basin margin (Weijermars et al., 1985; Stapel et al., 1996; Huibregtse et al., 1998; Jonk \& Biermann, 2002). The basin proper originated at the beginning of the Tortonian with the onset of regional strike-slip deformation induced by the rotation of compression from E-W to NW-SE. This was after strata of middle/late Burdigalian to Serravallian age had been laid down and highly deformed by subsequent tectonics (Völk \& Rondeel, 1964; Rondeel, 1965; Völk, 1967; Ott d'Estevou et al., 1990; Huibregtse et al., 1998). The latter deposits include three unconformity-bounded sequences: a middle/late Burdigalian sequence of marine marls and limestones grouped together as the Alamo Formation, a Langhian sequence of marine conglomerates, sandstones and algal limestones constituting the Gomara Formation and a Serravallian sequence composed of the conglomeratic and turbiditic Romano and Lomas Blancas members of the Umbria Formation (Völk \& Rondeel, 1964; Rondeel, 1965; Völk, 1967; Ott d'Estevou et al., 1990; Huibregtse et al., 1998). The stratigraphic hiatuses are expressions of brief periods of basin uplift and restructuration preceding a new, Tortonian main phase of basin formation. The presence of chiefly Alpujarride debris and deep-marine yellow marls in the Lomas Blancas Member reflects increased deformation during the 'Terminal Serravallian' tectonic phase (Völk, 1967). This tectonism culminated at the SerravallianTortonian transition with the development of an angular unconformity in response to the establishment of NW-SE tectonic compression (0tt d'Estevou et al., 1990).

The basal post-Serravallian sequence includes an unconformity-bounded succession that mainly comprises alluvial Mofar conglomerates and conglomeratic sandstones (lower Chozas Fm. cf. Huibregtse et al., 1998) of early/middle Tortonian age (Tortonian 1 of 0tt d'Estevou et al., 1990; Stokes \& Mather, 2000) and a Chozas sequence of later Tortonian age (upper Chozas Fm. cf. Huibregtse et al., 1998; Tortonian 2 of 0tt d'Estevou et al., 1990). Like the basal Tortonian sequence, the upper one, which at the base contains terrestrial conglomerates, marine conglomerates, sandstones and marls with well-bedded turbidites, overlies an angular unconformity that most probably developed in response to a pulse of enhanced NW-SE tectonic compression (Stokes \& Mather, 2000; 0tt d'Estevou et al., 1990). In latest Tortonian times the Azagador Member of the Turre Formation accumulated on top of the terminal Tortonian unconformity (Völk \& Rondeel, 1964; Rondeel, 1965; Völk, 1967). The continental Mofar sequence represents an episode of regional uplift, emergence and erosion that climaxed with a major phase of faulting and thrusting related to the development of the intra-Tortonian unconformity (Völk, 1967). The development of this hiatus coincided approximately with the outpouring of rhyolithicdacitic volcanics ( $~ 8 \mathrm{Ma}$ ) and the first tectonic activity along the Palomares Fault (Huibregtse et al., 1998). Major tectonic uplift, stratal deformation and erosion of the Chozas Formation 
occurred near the end of the Tortonian, just prior to the deposition of the Azagador Member which itself was influenced by uplifting along the Palomares Fault during a rotation of the principal compressional stress axis from NW-SE to NNW-SSE/N-S (Ott d'Estevou et al., 1990; Huibregtse et al., 1998). The Turre Formation accumulated until close to the end of the Messinian (sensu Stokes \& Mather, 2000). On top of the Azagador and Abad deposits, it includes the deep-water turbidites of the Santiago Member (upper Turre Fm.), which are unconformably overlain by laminated marls and mass-flow deposits with large blocks and slabs of gypsum derived from rising mountains (Van de Poel, 1994; Fortuin et al., 1995; Huibregtse et al., 1998). This time-equivalent of the Feos Formation overlies steeply dipping Tortonian and Messinian deposits. The unconformity at the base indicates vigorous subaerial erosion related to earlier tectonic uplift and stratal tilting (Van de Poel, 1994; Stokes \& Mather, 2000; Mather et al. 2001). The Tortonian-Messinian transition corresponds with the deposition of upper Abad marls in deep-water facies on top of the shallow-marine Azagador Member (and its lateral equivalent of lower Abad marls) in a tectonosedimentary setting related to the onset of $\mathrm{N}$-S compression that reduced leftlateral displacement along the Palomares Fault (Huibregtse et al., 1998). The Messinian Salinity Crisis is not represented by in-situ (Yesares-type) evaporites. Their absence suggests a stratigraphic hiatus separating the (pre-evaporitic) Santiago and (post-evaporitic) Feos sequences. The Neogene stratigraphic record ends with an Early Pliocene sequence of shallow-marine Cuevas marls, calcarenites and sands (lower Cuevas Fm. cf. Huibregtse et al., 1998; Pliocene 1 of 0tt d'Estevou et al., 1990) that transgressed an unconformity marking the MiocenePliocene transition (Fortuin et al., 1995) and is overlain by regressive Cuevas deposits (upper Cuevas Fm. cf. Huibregtse et al., 1998; Pliocene 2 of Ott d'Estevou et al., 1990). Following the development of an intra-Pliocene unconformity, which coincided with a change in orientation of the compressive stress field from N-S to NW-SE (Fortuin et al., 1995), the fluviomarine fan-delta conglomerates of the Espiritu Santo Formation were deposited in the Late Pliocene (Völk \& Rondeel, 1964; Stokes \& Mather, 2000; Mather et al., 2001). The PliocenePleistocene transition at its upper limit corresponds to a break in sedimentation signifying a brief period of uplift/erosion preceding the braided-river deposition of the Salmeron Formation (Stokes \& Mather, 2000; Mather et al., 2001).

The Vera-Garrucha Basin communicated in the north with the NNE-SSW oriented Pulpi Basin via the Pulpi Corridor (Veeken, 1983; Aellen-de La Chapelle, 1990). The northernmost part of the basin is divided into the similarly NNE-SSW trending La Hoya, Los Almendricos and Pozo de la Higuera corridors. These passages link up with the Hinojar Basin. E-W directed communication with the Huercal-0vera Basin occurred via the Las Norias Corridor. Sediment accumulation was controlled by vertical fault movements and sinistral strike-slip displacements along the margins of the corridors (Aellen-de La Chapelle, 1990). The initial sequence stratigraphic development (Veeken, 1983; Aellen-de La Chapelle, 1990) is very similar to that of the Vera-Garucha Basin: the older Neogene includes the unconformity-bounded Alamo, Gomara and Umbria Formations (Veeken, 1983). The upper Umbria Formation consists of Lomas Blancas conglomerates and yellow marls (Aellen-de La Chapelle, 1990), which accumulated during the 'Terminal Serravallian' tectonic phase. Following strong compressional deformation, these beds were succeeded by the unconformity-bounded Mofar Formation. In turn, these continental clastics and marine marls are overlain by the unconformity-bounded Chozas Formation, which is typified by shallow-marine conglomerates, deepmarine turbiditic sandstones and marls. 0nly from the time that the latter transgressive sedimentary series was formed, a structurally distinct Pulpi Basin existed. Its Miocene basin fill is completed with unconformably accumulated Azagador platform calcarenites and conformably overlying the preevaporitic Abad marls. Evaporitic and post-evaporitic Messinian strata are absent due to erosion/non-deposition indicated by a hiatus locally marked by an angular unconformity at the base of the Lower Pliocene. The Pliocene sequence consists of transgressively deposited, open-marine Cuevas marls with turbiditic sandstones (PI A of Aellen-de La Chapelle, 1990). The unconformably overlying Espiritu Santo Formation (PI B of Aellen-de la Chapelle, 1990) consists of shallow-marine and fluvio-marine marls and conglomerates. On top of this overall regressive sedimentary series continental Salmeron conglomerates have been unconformably laid down (Veeken, 1983; Aellen-de La Chapelle, 1990).

West of the Pulpi Basin occurs the E-W oriented HuercalOvera Basin (Briend et al., 1990). This is a complex graben system comprising several half-grabens and full grabens. Its development was affected by left-lateral strike-slip faulting in the Eastern Betic Shear Zone involving the Alhama de Murcia Fault. The basin communicated with the Guadix-Baza Basin via the E-W oriented Almanzora Corridor, a narrow depression controlled by E-W trending faults. The pre-Tortonian basin fill is poorly known. Undated red-coloured conglomerates and breccias are known in a setting suggesting structural distortion by the 'Terminal Serravallian' tectonic phase. The basin predominantly contains the unconformity-bounded Mofar and Chozas sequences (Tortonian 1 and 2 of Briend et al., 1990), which extend into the post-Serravallian Almanzora Corridor (tectonosedimentary units TSU-I/II and TSU-III of GuerraMerchán \& Serrano, 1993). Like the coeval deposits in the Lorca Basin (discussed below), the Mofar and Chozas sequences were deposited concurrently with the change from generally NE-SW directed extension to roughly N-S extension (Meijninger, 2006). This change in stress conditions resulted in subsidence that was controlled by a roughly E-W trending system of normal faults which acted as transfer faults and interacted with the southern extension of the NE-SW oriented Alhama de 
Murcia Fault (Mora-Gluckstadt, 1993). The Tortonian basin fill is generally overlain by a Messinian sequence of terrestrial and coastal conglomerates and/or relatively offshore-marine Abad marls (cf. Almanzora unit TSU-IV of Guerra-Mechán \& Serrano, 1993). Thus, the Azagador lithostratigraphic marker is missing, probably due to uplift associated with a change in the direction of extension from roughly E-W to roughly NW-SE. This uplift likely preceded detachment of the slab pulling at the Iberian Plate beneath the Betics (Meijninger, 2006) and successive tectonic uplift of the basin as a whole. In any case, evaporitic and post-evaporitic Messinian deposits are absent as well. The Neogene stratigraphic record of the basin terminates with a thin pre-inversion sequence of (supposedly) basal Cuevas deposits (Sanz de Galdeano \& Vera, 1992) and some scattered occurrences of the alluvial Espiritu Santo Formation.

Northeast of the Pulpi Basin, the Hinojar Basin devoped from the beginning of the Tortonian. 0verall, it evolved as a NE-SW trending and structurally north-westward progressing foreland basin with flexural subsidence and syn-sedimentary folding in front of the northwestwards thrusting sierra along the southern basin margin (De Larouzière et al., 1987; De Larouzière \& 0tt d'Estevou, 1990). The Tortonian basin fill comprises two major unconformity-bounded sequences of Mofarand Chozas-type sediments (Tortonian 1 and Tortonian 2/ Terminal Tortonian (de Larouzière et al., 1987; de Larouzière \& Ott d'Estevou, 1990). These deposits are succeeded by Azagador calcarenites and truncated Abad marls. Late Messinian deposits are absent. The final fill of the compressional/transpressional basin consists of Plio-Pleistocene alluvial clastics (de Lazourierre \& d'Estevou, 1990; Sanz de Galdeano \& Vera, 1992). The nearby Mazarron Basin, a quadrangular, N-S striking graben, originated during the late Tortonian. Its subsidence and sequence-stratigraphic development lasted until 'midMessinian' time, much like the Hinojar Basin, although the local stress field induced overall E-W directed extension/ transtension and comparatively little subsidence (de Larouzière et al., 1987; de Lazourière \& d'Estevou, 1990).

North of the Hinojar Basin, the NE-SW oriented Lorca Basin developed as a typical intramontane, presumably transtensional pull-apart structure between the Alhama de Murcia Fault and the contact of the Betic Internal and External Zones. A firstorder succession of six basin-wide rock sequences is distinguished within the post-Serravallian fill of the basin. Essentially, the sequence boundaries are isochronous discontinuities corresponding to minor unconformities at the basin margin (Wrobel \& Michalzik, 1999, Wrobel, 2000). Although rigourous datings are lacking, the sequences seem to be chronostratigraphically correlative with the Mofar (assuming a Tortonian rather than a Serravallian age), Chozas, Turre, Yesares and Feos Formations. These units correspond respectively to the Lower Pre-evaporitic Unit 1 (Soriana Fm. with Soriana Gypsum) and Lower Pre-evaporitic Unit 2 (Parilla Fm.), the Middle Pre-evaporitic Unit (Hondo Fm.), the Upper Pre- evaporitic Unit (lower and middle Serrata Fm.; with evaporitic beds attributed to the "Tortonian Salinity Crisis' (7.8 - 7.6 Ma; Krijgsman et al., 2000), the Evaporitic Unit (early upper Serrata Fm.; with Serrata Gypsum and non-outcropping halite (found in boreholes); representing the early, dominantly tectonics-induced phase of the Messinian Salinity Crisis; 5.965.50 Ma; Krijgsman et al., 1999a, 2000) and the PostEvaporitic Unit (late upper Serrata and El Prado Fms; representing the Lago Mare phase of deposition; 5.50-5.33 Ma; Krijgsman et al., 1999a; rejecting the inclusion of Pliocene strata: see Wrobel \& Michalzik, 1999 and Wrobel, 2000). The lower two main sequences (Tortonian I and Tortonian II of Montenat et al., 1990b) are separated by an angular unconformity that represents a period of tectonic reconfiguration of the Betic intramontane basins and elevation of Betic basement. Similarly, the terminal Tortonian change in facies at the transition between the relatively open-marine Chozas sequence and the relatively restricted marine Turre sequence was tied to a widespread tectonics-related modification of the physiographic setting of intramontane basins (Krijgsman et al., 2000). The base of the late Messinian Evaporite Unit has been described as an unconformable sequence boundary as well (Wrobel \& Michalzik, 1999; Wrobel, 2000).

Allochthonous Miocene formations predating the Burdigalian collision of Alboran and Iberia are exposed in the NE-SW trending Velez Rubio Corridor, which, as an inverted wrench furrow', corresponds to the ENE-WNW striking central part of the Internal-External Betic Boundary Zone (Hermes, 1978, 1984; Geel \& Roep, 1999). During the early Aquitanian, the overall turbiditic algal packstones of the Lepidocyclina Limestone Formation accumulated more or less simultaneously with the submarine fans of the Solana Formation on top of the Oligocene Calcarenite-Calcipelite and Upper Tabernas Formations. The lower boundary of the Lepidocyclina Limestone is generally sharp and conformable, suggesting a sudden change in depositional circumstances around the ChattianAquitanian transition. The same event may have led to the deposition of the Solana sandstones. Possibly, it triggered the accumulation of the Aljibe Arenites in the North African Flysch Trough as well. During the late Chattian-early Aquitanian the Ciudad Granada Formation, a transgressive syn-rift sequence of relatively fine-grained clastics that partly accumulated in deep-water graben structures, was laid down while extensional tectonics prevailed in the Western Mediterranean (Geel \& Roep, 1999; Serrano et al., 2007). These older formations have all been tectonized into imbricate units during the regionally important tectonometamorphic 'Aquitanian Paroxysm' when the 'Alboran Block' began to move westward and to disintegrate by rifting and thrusting (Geel \& Roep, 1999). In the southern Subbetic domain the accumulation of the Lepidocyclina limestones ended and these were conformably covered by the Upper Green Pelite and Fuente Formations of late Aquitanian 
to early Burdigalian age. The former (poorly preserved) succession of clay-rich marls with sandy turbiditic intercalations is the youngest pre-collision deposit of the South Iberian palaeomargin. Its deep-water deposition was apparently both initiated and terminated in a close causal relationship with the Aquitanian and Burdigalian paroxysms. A similar tectonostratigraphic relationship may have existed for the deep-water marls of the Fuente Formation. The collision of Alboran and Iberia is reflected by the intra-Burdigalian tectonic phase which ended rifting and caused the destruction of the Subbetic continental slope (Martín-Algarra et al., 1988; Sanz de Galdeano \& Vera, 1992). The post-collision breccias, conglomerates and sandstones of the late/middle Burdigalian Espejos Formation accumulated unconformably in a deep-water basin. Southward thrusting of the Subbetic interrupted their deposition just before the Middle Miocene deposition of the marine Maiz I and Maiz II Formations. These were deposited in a general strikeslip tectonic setting with pull-apart basins which were eventually destroyed by Late Miocene/Pliocene inversion tectonics (Geel \& Roep, 1999; age interpretations slightly modified; see also Sanz de Galdeano \& Vera, 1992).

The Fortuna Basin lies northeast of the Lorca Basin in between the Alhama de Murcia and Crevillente shear zones. The age of the sediments in this triangular extensional (pullapart) basin ranges from Late Miocene to Pliocene. Three basin-wide and in general conformable formations are distinguished (Garcés et al., 1998, 2001; Dinarès-Turell et al., 1999; see Lukowski \& Poisson (1990) for marginal hiatuses). The oldest is the Los Baños Formation. It is characterized by shallow-marine conglomerates, sandstones and evaporites (Lower Gypsum; Dinarès-Turell et al., 1999) grading into pelagic marls (Fortuna Marls) and turbidites of late Tortonian age, indicating a likely correlation with the Chozas Formation. As far as known, this sequence is unconformably underlain by Tortonian marls, limestones and breccia which may be correlative with the Mofar Formation (Lukowski \& Poisson, 1990). The Los Baños Formation is overlain by the Rio Chicamo Formation of latest Tortonian age (age slightly modified from Garcés et al., 1998). This formation comprises gypsiferous marls and massive evaporites (Chicamo Gypsum, Tale Gypsum, Librilla Gypsum) at the base and diatomites and marls at the top. The strata reflect a mixture of restricted shallow-marine to continental conditions of deposition and a semi-isolation of the basin that developed in association with transpressional uplift along the Alhama de Murcia Fault (7.8 - 7.6 Ma; Krijgsman et al., 2000; Garcés et al., 2001). The regressive succession correlates with those of the 'Tortonian Salinity Crisis' in the Lorca and Granada Basins (Krijgsman et al., 2000; see also Dinarès-Turell et al., 1999). The Rio Chicamo Formation grades upwards into the Rambla Salada Formation, a Messinian sequence composed of alluvial and lacustrine sediments with evaporitic horizons (Ribera Gypsum, Rambla Salada Gypsum) that is unconformably overlain by mainly continental sediments of Pliocene age. Only the southern and eastern parts of the Fortuna Basin were affected by the marine flooding event at the beginning of the Pliocene (Garcès et al., 1998). In the northwest the Fortuna Basin merges with the minor Hellin Basin, in which Tortonian basin conglomerates and sandstones (Cenajo Fm.) and calcareous marls (Casanueva Fm.) accumulated until intra-Tortonian tectonics reduced communication with the open-marine Mediterranean realm. This lead to deposition of continental marls and evaporites (Las Minas de Hellin Fm.) with diatomitic interbeds indicating episodic marine flooding during the remainder of the Tortonian (and early Messinian?; Servant-Vildary et al., 1990).

Towards the east the Fortuna Basin merges with the partly extensional Alicante-Cartagena Basin (Montenat et al., 1990c; Alfaro et al., 2002). The basin is continuous with the Mediterranean (North Algerian) Basin in the east. Onshore, a northern Bajo Segura Subbasin, a central Murcia Subbasin and a southern Campo de Cartagena Subbasin are distinguished (cf. Montenat et al., 1990c). The latter depocentre communicated with the Mazarron, Hinojar and Lorca Basins via the Escobar Basin. Pre-Tortonian deposits are known from the compressional Bajo Segura Subbasin. They include tectonically deformed formations mostly consisting of shallow-marine limestones and marls, to which Aquitanian-Burdigalian, late Burdigalianearly Langhian and Middle Miocene (prob. Serravallian; cf. El Relojero Fm.: see below) ages have been attributed (Montenat et $a l, 1990 \mathrm{c}$ ). The fill of the actual subbasin is made up by four principal stratigraphic sequences, ranging in age from Late Miocene to Quaternary. The sequences are bounded by unconformities and conformities that represent brief tectonic phases or eustatic events (Montenat et al., 1990c; Soria et al., 2001; Alfaro et al., 2002). The lowermost sequence is early/middle Tortonian in age. At its base, it consists of platform limestones, which accumulated in response to a rise in sea level (eustatic event E0 of Soria et al., 2001) and tectonic subsidence. After a sudden deepening of the basin (tectonic event E1 of Soria et al., 2001), these strata were replaced by coastal marine calcarenites and more open-marine marls. These are covered by coarse-grained turbidities that were abruptly deposited as the result of a brief period of uplift and erosion of the southern margin of the Bajo Segura Subbasin (units I to III and tectonic event E2 of Soria et al., 2001). Following a change from deepening-upwards to shallowing-upwards (eustatic event E3 of Soria et al., 2001), the second main sequence consists of a transgressive series of shallow-marine calcarenites and clastics grading successively to deep-marine marls with turbiditic sandstones and regressive shallow-marine calcarenites. These deposits are late Tortonian in age and locally rests transgressively on basement rocks (unit IV of Soria et al., 2001; unit T-II of Alfaro et al., 2002). Following an episode of sudden shallowing in the west and sudden deepening in the east (tectonic event E4 of Soria et al., 2001), they are isochronously overlain by an overall regressive sequence of 
latest Tortonian-Messinian age. This sequence partly consists of pelagic marls grading into shallow-marine sediments including clastics, reefal limestones and evaporites (unit V of Soria et al., 2001; unit T-M of Alfaro et al., 2002). The uppermost sequence comprises 'Pliocene $1^{\prime}$ open-marine marls (Hurchillo Marls Fm.), that were deposited unconformably during a rapid marine transgression (eustatic event E5 of Soria et al., 2001), and shelfal marine clastics (Rojales Sandstones Fm.). These are overlain by 'Pliocene 2 ' river floodplain deposits (Variegated Lutite Fm.) succeeded by Plio-Pleistocene fluvial channel beds (Segura Conglomerate Fm.; unit VI of Soria et al., 2001; unit P of Alfaro et al., 2002). Overall, this upwardsshallowing megasequence represents an eastward prograding depositional system (Soria et al., 2001).

The pre-Tortonian substratal deposits of the Murcia Subbasin include dolomitic breccias, which are conformably overlain by marine marls and sandstones (Los Garres Fm.) of Middle Miocene (prob. late Langhian) age (Montenat et al., 1990c). Yellow marls with turbiditic intercalations (El Relojero Fm.) are also known from the region. They have been dated as Serravallian (Montenat et al., 1990c). The marly deposits are overlain by a Tortonian sequence (Tortonian 1 of Montenat et al., 1990c) with red-coloured, continental to shallow-marine conglomerates (Cresta del Gallo Conglomerates; with NevadoFilabride debris) and sandstones at the base. They cover an angular unconformity and grade upwards into a series of deeper marine marls with turbiditic sandstone horizons (Atalaya Marls and Sandstones Fm.). These marls are truncated by an angular unconformity and succeeded by a Tortonian to Messinian sequence (Tortonian 2 - Messinian of Montenat et al., 1990c). The latter includes a transgressive-regressive depositional sequence with successively Tortonian conglomerates and sandstones, upwards-deepening Tortonian marls and upwards-shallowing Messinian marls of the Torremendo Formation, unconformable sandy limestones (La Virgen Fm.) and marls with evaporites (San Miguel Fm.) of late Messinian age. Reportedly, the contact with the Lower Pliocene (partly Hurchillo Marls Fm.; Pliocene 1 of Montenat et al., 1990c), and the overlying Upper Pliocene (partly Rojales Sandstones Fm.; Pliocene 2 of Montenat et al., 1990c) is partly conformable.

The older Neogene rocks are rarely exposed in the south (Montenat et al., 1990c). They consist of Early Miocene marls with sandy turbidites and Middle Miocene brecciated and marly strata. The upper limit of the Middle Miocene sequence corresponds to an angular unconformity that is overlain by red conglomerates (Tortonian 1 of Montenat et al., 1990c; with Nevado-Filabride debris). The succeeding Tortonian sequence (Tortonian 2 of Montenat et al., 1990c) is characterized by marls with sandy turbidites. This sequence is unconformably overlain by Tortonian calcarenites and conformably deposited Messinian. These deposits are separated from the PlioPleistocene by another angular unconformity at its base (Montenat et al., 1990c).

\section{External Betic Basins (Fig. 6)}

During the middle/late Burdigalian-Serravallian, the Betic External Zone developed as an overall $\mathrm{N}(\mathrm{N}) \mathrm{W}$-vergent, thinskinned fold-and-thrust belt (cf. Croese, 1982; de Ruig, 1990, 1992), which included the Proto-Subbetic and Proto-Prebetic zones. At the same time, the Betic Internal Zone was affected by extension leading to the formation of various fault systems from the Burdigalian onwards. Late Miocene, NNW-SSE to NW-SE compression of the Internal and External Zones in particular caused further faulting and folding. As a final result, the present Subbetic includes tectonic units of Burdigalian age that have been thrusted north-westward on the northern side and south-eastward on the southern side of the collision zone. However, the general structure of the Subbetic indicates a predominantly top-to-the-north(north)west sense of kinematic movement, like the Prebetic. Correspondingly, the sedimentary basins of the authochthonous Subbetic and Prebetic zones are surrounded by structural highs.

The westernmost Ronda Basin is a relatively minor intramontane depocentre that originated in the inner southwestern Subbetic Zone. The Late Miocene compression of the region is reflected by the wedging-out of the younger basin fill towards an intra-basinal high, the Sierras de Salinas (Gläser \& Betzler, 2002). Three unconformity-bounded sequences are distinguished (not shown in Fig. 6). The oldest largely consists of continental conglomerates (Tajo Fm.) and equivalent marine marls and calcarenites. This sequence is assumed to be early/ middle Tortonian in age (Sequence 1 of Gläser \& Betzler, 2002; Serrano Lozano, 1980).The upper limit of this sequence is proximally marked by an angular unconformity, which is overlain by a transgressive-regressive series of mostly marine sandstones (El Gastor Fm.), calcarenites (Setenil Fm.) and marls (La Mina Fm.) of late Tortonian to earliest Messinian age (Sequence 2 of Gläser \& Betzler, 2002; Serrano Lozano, 1980). This second sequence is locally truncated by an angular unconformity that was formed in association with uplift of the Sierra de las Salinas (Gläser \& Betzler, 2002). It is succeeded by an algal limestone deposit (Las Mesas Fm.) of Messinian age (Sequence 3 of Gläser \& Betzler, 2002; Serrano Lozano, 1980).

The Moratalla Basin is located north of the Crevillente Fault and is surrounded by the Subbetic and Western Prebetic. The initial, Late Oligocene to Burdigalian basin fill (Murtas Fm.) consists of marine marlstones with conglomeratic sandstones at the base (Grero Marlstone Mb.) and coarse-grained sandstones at the top (Celada Sandstone Mb.). The stratigraphic ages of these units are not well known and no intra-formational unconformities have been identified (Hoedemaeker, 1973). In analogy with the stratigraphic development of nearby-located Prebetic basins (see below), the oldest, relatively coarse-grained and presumably (mainly) continental strata are tentatively attributed to the late Chattian and early Aquitanian (age 
slightly modified from Hoedemaeker, 1973). Similarly, the intermediate marly succession of Aquitanian to early Burdigalian age is probably unconformity-bounded and overlain by (Celada) sandstones of middle/late Burdigalian age (age slightly modified from Hoedemaeker, 1973). The sandstones are unconformably succeeded by marine limestones (Roble Limestone Fm.) of Langhian age. In turn, these are conformably succeeded by a Middle Miocene rock series (Trieta Fm.) comprising calcareous deposits of late Langhian age (lower Moratalla Marlstone Mb.), Serravallian olistostromes (Benamor Geröllton Mb.) and early Serravallian conglomerates (Turmal Conglomerate Mb.) overlain by marlstones (upper Moratalla Marlstone Mb.) of Serravallian age. The conglomerates overly an angular unconformity at the Langhian-Serravallian transition (Hoedemaeker, 1973).

A short distance further eastwards in the northern Subbetic Zone, the rhomb-shaped Abaran Basin developed along the E-W striking sector of the Socovos Fault, a right-lateral strikeslip fault system bordered at its northern side by the Central Prebetic (Van der Straaten, 1990, 1993). This tiny intramontane depression is interpreted as a pull-apart basin that opened and step-wise subsided in response to episodic E-W oriented extensional stress. Its (preserved) fill is a latest Serravallianearliest Tortonian succession comprising three marine sequences of mainly deltaic sediments delimited by angular unconformities (Van der Straaten, 1990, 1993). The punctuated tectonic activity is attributed to the widespread "Terminal Serravallian' tectonic phase.

In the Prebetic Zone basins developed in close relationship with tectonic subsidence of the South Iberian crust. Until the early Burdigalian this was governed by pre-thrusting extension and by syn-thrusting compression at later times (Kenter et al., 1990). Previously, the sedimentary record of the older Neogene of the Prebetic was uniformly subdivided by Sanz de Galdeano \& Vera (1992) into four unconformitybounded marine sequences. These are respectively Aquitanianearly Burdigalian, later Burdigalian-early Langhian, late Langhian-early Serravallian, and late Serravallian in age. However, on the basis of regional stratigraphic comparisons and correlations a minor revision seems to be warranted.

Thus, the age of the lowermost continental red sands and conglomerates (Colorados Fm.) in the Central Prebetic east of Jumilla is re-interpreted as (late) Chattian to early Aquitanian (cf. IGME, 1974; age modified from Croese, 1982). These rocks are truncated by an angular unconformity. Similar to the late Aquitanian and Burdigalian deposits elsewhere in the Central Prebetic (IGME, 1974; Croese, 1982; Sanz de Galdeano \& Vera, 1992), the basal Neogene strata in the Jumilla region are assumed to have been transgressed and thickly covered by thick, late Aquitanian to Serravallian limestones and marls (Alberquilla Fm.). These deposits encompass an unconformable intra-Burdigalian sequence boundary that signifies the onset of rapid post-collisional tectonic subsidence, an unconformity at the base of the Langhian and an intra-Serravallian sequence boundary that marks the beginning of the 'Terminal Serravallian' tectonic phase (cf. IGME, 1974; Kenter et al, 1990). At the top, the formation grades laterally into breccias, conglomerates, conglomeratic marls and limestones (Saltador Fm.). The latter marine deposits are interpreted to have been gravitationallyemplaced during the 'Terminal Serravallian' tectonics. They are succeeded by a sequence of bioclastic limestones, marls and coarse clastics (Jumilla Fm.). Because of the prominent angular unconformity at its base, the age of the sequence is interpreted (in accordance with biostratigraphic control and relative stratigraphic position) as early/middle Tortonian (cf. IGME, 1974; modified from Croese, 1982). The stratigraphic record of the Central Prebetic terminates with continental deposits of late Tortonian to Pliocene age. Consequently, a close sequence stratigraphic similarity is inferred for the Upper Oligocene and Neogene of the Central Prebetic basins and the Moratalla Basin (see above), as well as for the basins of the Western Prebetic (modified from Sanz de Galdeano \& Vera, 1992).

Tectonostratigraphically, the Eastern Prebetic is better known than the other Prebetic areas. The tectonosedimentary subdivisions and stages of basin restructuration (0tt d'Estevou et al., 1988; de Ruig, 1992; Geel et al., 1992, Geel, 1995; Montenat et al., 1996) are comparable to those of the Central and Western Prebetic sectors. Basically, the chronologies of the tectonic events governing the Miocene development of the Prebetic and Subbetic are similar. Diapirs of Triassic evaporites and variegated mudstones developed in the Eastern Prebetic in association with extension from before the late Aquitanian (de Ruig, 1992). They evolved further during the "Terminal Serravallian' tectonic phase in concurrence with stratal tilting, uplift and erosion and consequent formation of olistostromic deposits (Colgorrubio Fm.; Cater, 1987). Compression occurred episodically throughout the Miocene, mainly trending between NW-SE and N-S (Montenat et al., 1996). Extension occurred especially during the Chattianearly Aquitanian and Serravallian-Messinian (de Ruig, 1992). Major syn-tectonic unconformities and prominent lithostratigraphic changes occur at the sequence boundaries near the base of the Aquitanian (within sequence $\mathrm{Ne}-\mathrm{O}$ of de Ruig, 1992), within the Aquitanian (base of Cycle I and Ne-1 of resp. Geel et al., 1992 and de Ruig, 1992) and Burdigalian (base of Cycle II and Ne-2 of resp. Geel et al., 1992 and de Ruig, 1992), and at the base of the Serravallian (base of Cycle III and Ne-3 of resp.Geel et al., 1992 and de Ruig, 1992; age after de Ruig, 1992), Tortonian (base of sequence Ne-4 of de Ruig, 1992; age modified from de Ruig (1992) after Geel et al., 1992; Montenat et al., 1996) and Plio-Quaternary (Ott d'Estevou et al., 1988; Montenat et al., 1996). Conformable sequence boundaries have been noticed at the Burdigalian-Langhian transition and within the Tortonian, dividing the latter interval into a lower marine and an upper continental sequence (0tt d'Estevou et al., 1988; Montenat et al, 1996). Important changes of the polyphase 
tectonic subsidence occurred in 'mid-Chattian' time (onset of Phase III), at the beginning of the Aquitanian (transition of Subphases IIIa and IIIb), at the beginning of the Burdigalian (onset of Phase IV), in Burdigalian time (transition of Subphases $\mathrm{IVa}$ and $\mathrm{IVb}$ ) and at the beginning of the Serravallian (onset of Phase V) and Tortonian (onset of Phase VI; Geel, 1995). The intra-Aquitanian hiatus is correlated with an abrupt transition from regional extension to compression (de Ruig, 1992) and the beginning of metamorphism of stacked Alpujarride nappes (Geel et al., 1992). The angular intra-Burdigalian unconformity is attributed to the onset of northward thrusting of Internal Zone units over External Zone units (de Ruig, 1992; Geel et al., 1992). The formation of the angular unconformity at the base of the Serravallian coincided with an anti-clockwise rotation of the maximum compressional stress that transformed the Eastern Prebetic into a right-lateral transpressional belt (de Ruig, 1992) in response to the collision of the Kabylies with Africa (Geel et al., 1992; Vergés \& Sàbat, 1999).

\section{Betic Foreland Basins (Fig. 6)}

Northwest of the Gibraltar Arc, i.e. at the westernmost part of the arcuate Betic-Rif thrust-and-fold belt, the Gulf of Cadiz straddles the diffusely deformed eastern sector of the E-W trending Azores-Gibraltar fracture zone. In this marine realm between the Iberian Massif and the Guadalquivir Bank (an ENE-WSW trending horst of Mesozoic basement) the Mesozoic Algarve Basin was transformed into a E-W oriented foreland basin by the Middle and Late Miocene, with NNW-SSE compression controlled by the northward drift of Africa (Riaza \& Martínez del Olmo, 1996). During this compression and the contemporaneous westward motion of the accretionary Gibraltar Arc of the 'Alboran Block', concentric wedges of fold and thinskinned thrust belts and massive olistostromes of the Gibraltar Arc Allochthon (Torelli et al., 1997; Medialdea et al., 2004) were emplaced south of the Algarve Basin, while a complex of faults was active in the area (Maldonado et al., 1999; Maldonado \& Nelson, 1999). Onshore in the Algarve, six first-order rock sequences are distinguished in the basin fill. The oldest onlapped the Mesozoic substratum in a platform setting. It is Burdigalian to Serravallian in age and dominated by marine calcareous sandstones and sandy limestones (Lagos-Portimão Fm.). It may be divided into subsequences on the basis of an intra-Burdigalian unconformity and (less obvious) unconformities / lithological discontinuities at the base and top of the Langhian and in the Serravallian (Atunes \& Pais, 1993; Pais et al., 2000). The overlying Tortonian sequence of predominantly marine sandstones is bounded by distinct breaks in sedimentation at the basal Serravallian-Tortonian transition and at its intra-Tortonian top (Pais et al., 2000). The succeeding marine limestones and fine-grained sandstones (silts) of late Tortonian to Messinian age (Cacela Fm.) are overlain by an unconformity-bounded sequence of Zanclean sands (Olhos de
Agua Sands). These (mainly) continental deposits are covered by a largely Piacenzian to early Pleistocene succession comprising continental sands, marls, clayey limestones and lignites (Morgadinho and Algoz deposits), which, in turn, are unconformably succeeded by late Pleistocene continental sands (Faro-Quarteira Fm.; Atunes \& Pais, 1993; Pais et al., 2000).

Eight sequences are distinguished in the offshore Gulf of Cadiz area: a Late Oligocene - (?) Early Miocene sequence (Unit UO-LM of Maldonado et al., 1999), a Langhian to early Tortonian group of three sequences (seqs Atlantida-1, -2 and -3 of Riaza \& Martínez del Olmo, 1996; Unit M1 of Maldonado et al., 1999; Unit D of Lopes \& Proença Cunha, 2000), a late Tortonian sequence (seq. Betica of Riaza \& Martínez del 0lmo, 1996; Unit M2 of Maldonado et al., 1999; Unit E of Lopes \& Proença Cunha, 2000), a Messinian sequence (seq. Andalucia of Riaza \& Martínez del Olmo, 1996; Unit M3 of Maldonado et al., 1999), a latest Messinian to Early Pliocene sequence (Marismas of Riaza \& Martínez del 0lmo, 1996; Early Pliocene Unit P1 of Maldonado et al., 1999; Early Pliocene Unit F of Lopes \& Proença Cunha, 2000) and a Late Pliocene to Pleistocene sequence (seq. Oriel of Riaza \& Martínez del Olmo, 1996; Unit P/O of Maldonado et al., 1999; Unit G of Lopes \& Proença Cunha, 2000). They are generally bounded by erosional unconformities and correlate in part with those in the Algarve.

After late Chattian and early Aquitanian extensional and transpressional deformation in the area of the Gulf of Cadiz along a transcurrent fault system, the late Aquitanian and Burdigalian westward motion of Alboran lead to the development of a tectonically active accretionary fore arc around the emergent Gibraltar Arc (and the closure of the North African Flysch Trough). Following the extension of the 'Alboran Block' and the subsidence of its adjoining foredeep with the associated precursory olistostrome emplacement in Langhian-early Tortonian times, suddenly increased rates of tectonic subsidence in late Tortonian and late Early Pliocene time triggered the emplacement of the giant olistostrome masses of the Gibraltar Arc Allochthon (Maldonado \& Nelson, 1999; Maldonado et al., 1999; Maestro et al., 2003).

Towards the east, the Algarve Basin merges with the Guadalquivir Basin, an elongate, ENE-WSW trending foreland basin situated between the Iberian Massif and the Subbetic mountain chain. This basin has a distinct asymmetrical geometry with sediment thicknesses increasing southeastward) The basin originated at the end of the Serravallian from the Aquitanian Proto-Guadalquivir Basin in response to increased thrust loading. The Guadalquivir Basin was part of the North Betic Corridor that connected the Atlantic with the Mediterranean until the late Tortonian (Sanz de Galdeano \& Vera, 1992). The depocentre of the newly reshaped foreland basin migrated north-northwestwards in parallel with the displacement of the adjoining Subbetic thrust belt in the same direction. In the process, the rootless and highly chaotic Guadalquivir Allochthon, a late Tortonian tectonosedimentary 
complex of Mesozoic and Tertiary rock units comprising diapirically emplaced Triassic evaporites and olistostromes, was formed along the southern basin margin. This was in front of the Subbetic nappe stack that was moving basinward during continued thrust loading (Flinch et al., 1996; Berástegui et al., 1998; Fernández et al., 1998). The crustal-foreland shortening and flexuring that had given rise to the basin, ceased in the late Tortonian. That is soon after the tectonic closure of the North Betic Corridor in the east and the consequent severing of marine communication between the remaining Guadalquivir Basin and the Western Mediterranean. This fragmentation of the basin was caused by thrust spreading in the region of the contemporaneously rising Western Prebetic (Sierro et al., 1996). In addition to deformation due to compressional stress, the progressive foreland surface loading of the polyphase Betic nappe stack onto the South Iberian lithospheric plate caused bending of the lithosphere and load-induced subsidence of the Guadalquivir Basin. Especially so in the post-collisional phase of late Burdigalian/Langhian and Serravallian overthrusting which followed upon the areally extensive late(st) Chattianearly Aquitanian episode of extension and the pre-collisional late Aquitanian-early Burdigalian period of contractional deformation caused by the expulsion of the 'Alboran Block' (Van der Beek \& Cloetingh, 1992; Biermann, 1995). The Tortonian closure of the originally deep-marine North Betic Corridor was caused by folding and uplifting of the eastern half of the foredeep and the northward transport and emergence of the adjoining Prebetic mountain chain (especially the SSW-NNE striking thrust imbricates of the Sierra de Cazorla and the thrust anticlines of the Sierra Segura).

Six (seismo)stratigraphic sequences bounded by unconformities that appear to correlate with third-order chances of the global sea level, are distinguished in the Guadalquivir basin for the Middle and Late Miocene (Fernández et al., 1998; Berástegui et al., 1998). Older, (Late) Oligocene and Early Miocene deposits are absent. Deposits of that age accumulated farther to the south in the Proto-Guadalquivir Basin, i.e. in the pre-collision, external Subbetic area including the Moratalla Basin. Burdigalian deposition took also place in a precursor Guadalquivir Basin still located in the same general region (Sanz de Galdeano \& Vera, 1992), with post-collision strata accumulating in the newly formed North Betic Foreland Basin. From Langhian times onwards the mobile ProtoGuadalquivir trough extended northward as far as the postSerravallian Guadalquivir Basin. The in situ (late) Langhian to Serravallian deposition is represented by a three-fold succession with diatomaceous marls (Sequences 1, 2 (syn-extensional) and 3 of Fernández et al., 1998; correlative with sequences Atlantida-1 and 2 of Riaza \& Martínez del 0lmo, 1996). The Late Miocene fill of the actual Guadalquivir Basin consists of two Tortonian (syn-compression) sequences with diatomaceous marls (Sequences 4 and 5 of Fernández et al., 1998; sequences Atlantida-3 and Betica of Riaza \& Martínez del 0lmo, 1996;
Sequence 5 correlated with Sequences A and B (lower part) of Sierro et al., 1996) and a single (post-compressional) sequence of latest Tortonian to Messinian age without diatomaceous marls (Sequences B (upper part) and C of Sierro et al., 1996; Sequence 6 of Fernández et al., 1998; sequence Andalucia of Riaza \& Martínez del Olmo, 1996; age modified after Sierro et al., 1996). The latter sequence is characterized by unconformably deposited carbonates (Niebla Calcarenite Fm.) with clayey deposits (Gibraleon Shales Fm.) on top (Sierro et al., 1996). The Plio-Quaternary sediments prograded westward that is parallel to the basin axis. The Early Pliocene is represented by sandy deposits (sequence Marismas of Riaza \& Martínez del Olmo, 1996; particularly Trigueros Sands and Huelva Sands Fms (Sequence D of Sierro et al., 1996)., lower Bonares Sands Fm. (Early/Middle Pliocene; Sequence E of Sierro et al., 1996).

\section{Tectonostratigraphy of the Alboran Basin (Figs 4, 7; Appendices 1 - 7)}

The prolonged continent-continent collision of Africa and Iberia resulted ultimately in the Alboran Sea, a large extensional basin at the centre of the Betic-Rif orocline. A diversity of geodynamic models has been proposed for this basin (see above), making its interpretation a matter of controversy. However, it is generally agreed that, subsequent to a Paleogene period of orogenic thickening of the lithosphere by collisional stacking (accompanied by HP/LT metamorphism; Rosenbaum \& Lister, 2004), crustal stretching occurred in tandem with removal of lithospheric mantle during Chattian ( 27 Ma) to Tortonian (8 - $9 \mathrm{Ma}$ ) times (Platt et al., 1998; Comas et al., 1999). This crustal stretching was accompanied by LP/HT metamorphism (thermal peak between $23 \mathrm{Ma}$ and $21 \mathrm{Ma}$; Platt et al., 2003). The concurrent stretching and thinning of the crust was induced by the pre-Middle Miocene emplacement of hot asthenospheric mantle (Morley, 1993) and block movements (including normal faulting, rifting and peripheral thrust faulting) related to the westward move of the 'Alboran Block'. The crustal thinning may have led - upon the cessation of thermal perturbation and the establishment of a NNW-SSE directed convergent stress regime of compressional folding and faulting (subsequent to the compression linked to relatively limited, almost perpendicular extensions in the Middle Miocene and early Late Miocene; Morley, 1993) - to a Tortonian episode of contractive re-organization culminating with thermal subsidence and tectonic collapse of the reduced and weakened crust in the central part of the Alboran Domain. Onshore, the surrounding mountains (sierras) emerged more or less simultaneously at the beginning of a generalized period of folding, reverse faulting and structural inversion of previous normal fault systems. The primary mechanical causes of the preceding rifting process (that was at times interrupted by compressional events) remain controversial. Conceivably, different causes governed different episodes of extension. 


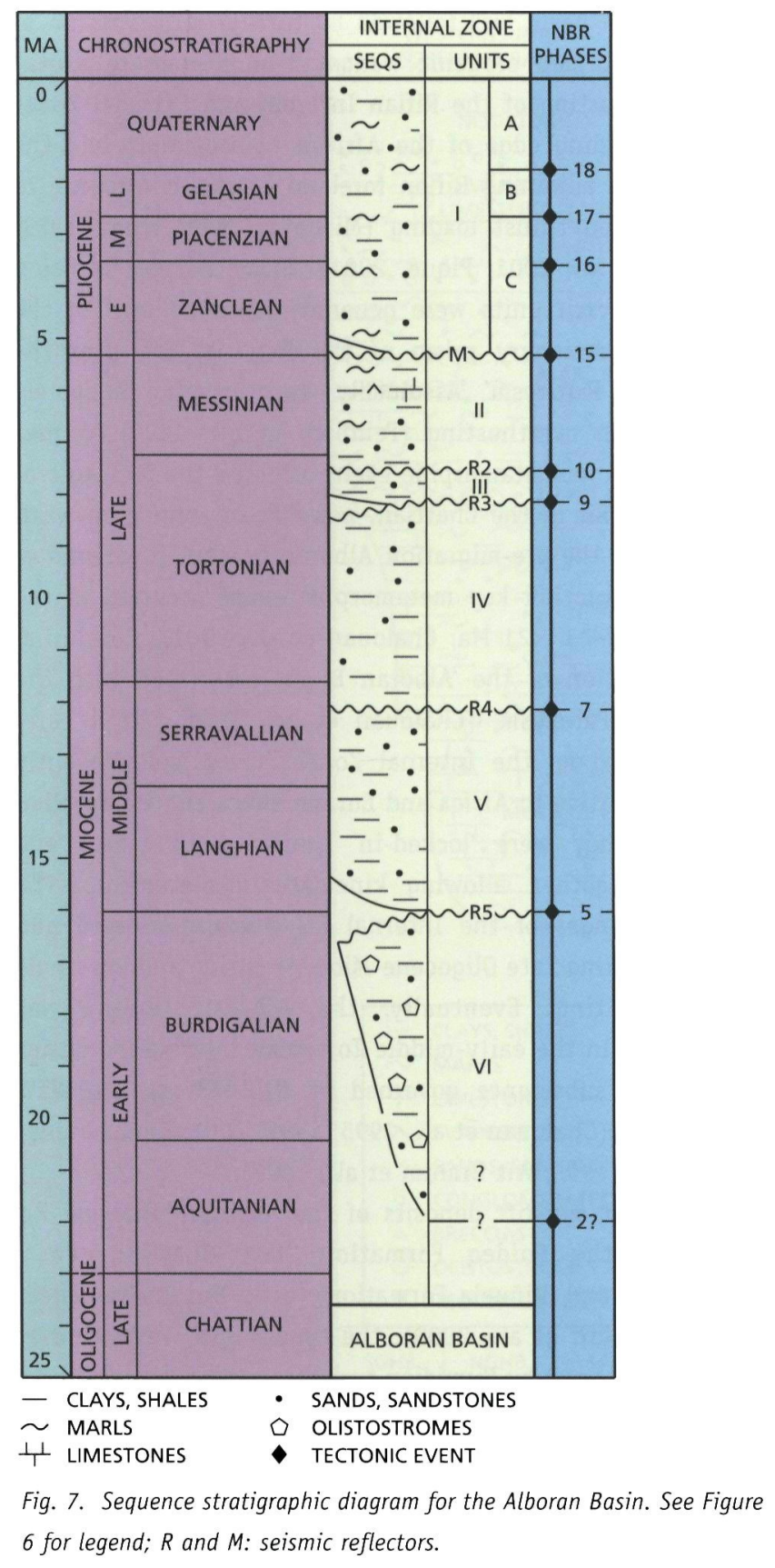

Thus, extension may have been caused by removal of mantle lithosphere and consequent thinning of the lithosphere (by the underlying, hotly convecting mantle). Alternatively by delamination of the lithosphere (by the gravitational peelingoff and sinking-down of the dense mantle lithosphere into the less dense mantle underneath) or by back-arc extension (through slow (NNW-SSE) plate convergence and rapid, NNWSSE ( 23 - 16 Ma) and ENE-WSW ( 16 - 11 Ma) subduction slab roll-back facilitated by E-W lithosphere tearing along the African margin and E-W slab detachment under the Betics; Spakman \& Wortel, 2004). This resulted in two regimes of nearly orthogonal, generalized rifting (Martínez-Martínez \& Azañón, 2002; Rosenbaum \& Lister, 2004) which succeeded each other when the roll-back subducting zone reached the African-
Maghrebian palaeomargin and the North Algerian Basin opened. In all models, the final causal mechanism is the collisional convergence of Africa and Europe,which led to the replacement of cold lithosphere by hot asthenosphere, uplift of the crust and the establishment of an extensional crustal stress regime in a larger-scale compressional setting. The present Alboran Basin may actually have originated after a final accretion of the Betic and Rif fold-and-thrust belt with the Iberia and African plates in the Tortonian ( $8-9 \mathrm{Ma}$ ), by which time westward movement, thinning and extension of the overriding 'Alboran Block' came to an end simultaneous with the cessation of subduction roll-back. As a convergence-controlled, partial 'thermal sag basin' it may have come into being by 'postorogenic compressional collapse'. It was open to the North Algerian Basin in the east and closed to the west by the Gibraltar Arc, i.e. the Atlantic-facing collision front of the 'Alboran Block' (Platt \& Vissers, 1989; García-Dueñas et al., 1992; Morley, 1993; Vissers et al., 1995; Lonergan \& White, 1997; Rosenbaum \& Lister, 2004; see Tandon et al. (1998) for a discussion of later rifting in part of the basin, inferred to have been due to time-transgressive migration of delaminating lithosphere). After the late Aquitanian-early Burdigalian, the main period of migration, thinning and fragmentation of the 'Alboran Block', subduction-related magmatism occurred abundantly as testified by numerous post-Burdigalian seamounts (generally 22-6 Ma; Hernández et al., 1987; Lonergan \& White, 1997; Fernández-Soler, 2001) and the Alboran Ridge (Fig. 2), an approximately SW-NE trending transpressional (strike-slip) feature of volcanic and tectonic origin that is locally emergent (Alboran Island; Campos et al., 1992).

Tectonostratigraphically, the present-day Alboran Sea basin is the outcome of six developmental stages represented by an Early Miocene to Recent sedimentary fill consisting of a similar number of marine (seismo)stratigraphic units (Units IVI of Jurado \& Comas, 1992; Comas et al., 1992, 1999). These depositional sequences are mostly bounded by angular unconformities. They have been dated and interpreted by extrapolation and generalization of commercial drilling results. Thus, rifting occurred episodically from the late Aquitanian(?) to the Tortonian, with major episodes having different tectonostratigraphic signatures. As a whole, the sequence stratigraphic architecture of the offshore Alboran Basin is found to be broadly correlatable with those of the onshore basins in the Betic and Rifian Internal Zones (compare Figs 5 - 8). The oldest basin fill unit is characterized by olistostromes of late Aquitanian(?) - Burdigalian age (Unit VI). It represents a phase of initial syn-rift and transgressive deposition and tectonic subsidence that coincided with the early westward drift of the 'Alboran Block', comprising the pre-collision stage of rapid cooling and exhumation of its basement rocks (prior to surfacing at 18 Ma; Platt et al., 1998, 2003; Comas et al., 1999). Like previously, Alboran was probably still an overall terrestrial realm of non-deposition/erosion (e.g. Watts et al., 
1993). Apparently, deposition of the olistostromic sequence commenced during the 'Aquitanian Paroxysm', soon after the first magmatic activity in the Alboran Domain (22 - $23 \mathrm{Ma}$; Torres-Roldán et al., 1986), and lasted until after the 'Burdigalian Paroxysm' (not accurately dated). A two-fold main phase of rifting leading to pronounced development of largescale, low-angle extensional detachment faults (resulting in crustal thinning) is envisioned for the Langhian-Serravallian and late Serravallian-Tortonian intervals (Units V and IV). It was initiated with accumulation of clays and marls including volcanic and volcaniclastic interbeds (Unit V) that were laid down on a major angular unconformity near the BurdigalianLanghian transition. It was ended by a brief episode of tectonic compression resulting in an angular unconformity at the top of a sequence of turbiditic sands, silts and clays with volcanic and volcaniclastic levels (Unit IV). The intermediate, intra-Serravallian sequence boundary and angular unconformity ares supposed to mark the onset of the 'Terminal Serravallian' tectonic phase. Subsequent post-rift basin shortening corresponded with the deposition of a late Tortonian sequence of (silty) clays with turbiditic sandstone interbeds and volcanic debris (Unit III) and a latest Tortonian-Messinian sequence of shallow-marine calcareous and clayey deposits with sandy and volcanic intercalations and occasional gypsum and anhydrite horizons (Unit II). The latter accumulated after a pronounced pulse of compression (Chalouan et al., 1997). At the end of the Messinian Salinity Crisis, Unit II was eroded due to emergence caused by another pulse of compression, prior to Pliocene-Quaternary clays and marls (Unit I) began to accumulate on the angular unconformity (Chalouan et al., 1997; Comas et al., 1999). Deposition was governed by wrenchtectonics, including interacting strike-slip fault systems in a transtensional stress regime that evolved into a regime of transpressional stress conditions (Campillo et al., 1992). Under the latter stress regime an Early Pliocene unconformity developed (Tandon et al., 1998) that may have originated during a rotation of the stress field from roughly N-S to NNW-SSE (Campillo et al., 1992) and is probably coeval with intrabasinal inversions and further uplifting of the Alboran Ridge (from 3.4 Ma; Comas et al., 1999), prior to terminal Pliocene compression ( 2.6 - 1.8 Ma; Chalouan et al, 1997).

\section{Rif Basins (Figs 4, 8; Appendices 1 - 7)}

\section{Internal Rif Basins (Fig. 8)}

The accretionary collision of the 'Alboran Block' with the AfricanMaghrebian palaeomargin proceeded much like the one with the South Iberian palaeomargin. The resultant destruction of the North African Flysch Trough (see previous; Fig. 5) ended in the late Burdigalian with the deposition of Numidian flysch in an increasingly shrinking basin that warped the westward migrating 'Alboran Block' (Feinberg et al., 1990). The closure of the flysch basin was followed by further structuration of the newly formed orogenic wedge through west to southdirected thrusting of the Rifian Internal and External Zones onto the leading edge of the African palaeomargin and the formation of adjoining Rifian foreland basins in response to the associated thrust loading (Michard, 1976; Wildi, 1983; Chalouan et al., 2001; Piqué, 2001). Unrooted post-collision Numidian Flysch units were generally thrusted over of the evolving accretionary prism of the External Rif after the 'Burdigalian Paroxysm'. Assumedly, backthrusting happened coevally with overthusting (Feinberg et al., 1990). A precollision tectonometamorphic event affected the Mesozoic of the eastern Rif in the Chattian, possibly in connection with extension of the pre-migration Alboran Domain (Chalouan et al., 2001). Another key metamorphic event occurred in the Aquitanian ( 23 - $21 \mathrm{Ma}$; Chalouan et al., 2001), i.e. during the exhumation of the 'Alboran Block' associated with the 'Aquitanian Paroxysm' (Chalouan et al., 2001). Until early Burdigalian time, the Internal Zones moved independently westward relative to Africa and Europe. Since the 'Burdigalian Paroxysm' they were 'locked-in' against both plates and deformed together, allowing kinematic displacements. The mountain ranges of the Internal Rif Domain emerged and collapsed during Late Oligocene-Miocene rifting and low-angle normal faulting. Eventually, the Alboran terrane was transformed in the early-middle Tortonian into marine basins by tectonic subsidence governed by NNE-SSW to ENE-WSW compression (Chalouan et al., 1995, 1997, 2001; Benmakhlouf \& Chalouan, 1995; Aït Brahim et al., 2002).

The oldest syn-rift deposits of the northern Internal Rif belong to the Fnideq Formation (late Chattian- early Aquitanian) and 'Viñuela Formation' (early Burdigalian) near Ceuta (El Kadiri et al., 2000), the type Fnideq Formation at Fnideq (overthrust by Numidian turbidite sandstones; Feinberg et al., 1990; Ouazani-Touhami \& Chalouan, 1995), and the Fnideq Formation and Sidi Abdeslam Formation (early Burdigalian) in the Tetouan-Martil Basin, a quadrangular depocentre that opened by NE-SW extension at the end of the Oligocene (Feinberg et al., 1990; Benmakhlouf \& Chalouan, 1995; Maate et al., 1995; Ouazani-Touhami \& Chalouan, 1995). These molassic strata regionally transgressed the block-faulted Ghomaride Complex (the highest tectonic element of the Rif) with high-density turbidity currents depositing clastics in a network of small 'basins' with subsidence governed by normal faulting (Zaghloul et al., 2003). After the HT metamorphic episode ( 23 - $21 \mathrm{Ma}$ ) and exhumation, non-deposition and erosion during the 'Aquitanian Paroxysm', early Burdigalian strata (yielding the first detritus of Sebtide Complex provenance) onlapped early Aquitanian deposits in the Tetouan-Martil Basin with an angular unconformity (0uazaniTouhami \& Chalouan, 1995). This unconformity indicates tectonic uplift and thrusting of Internal Rif nappes (Maate et al., 1995). Regionally, both formations record a succession of 


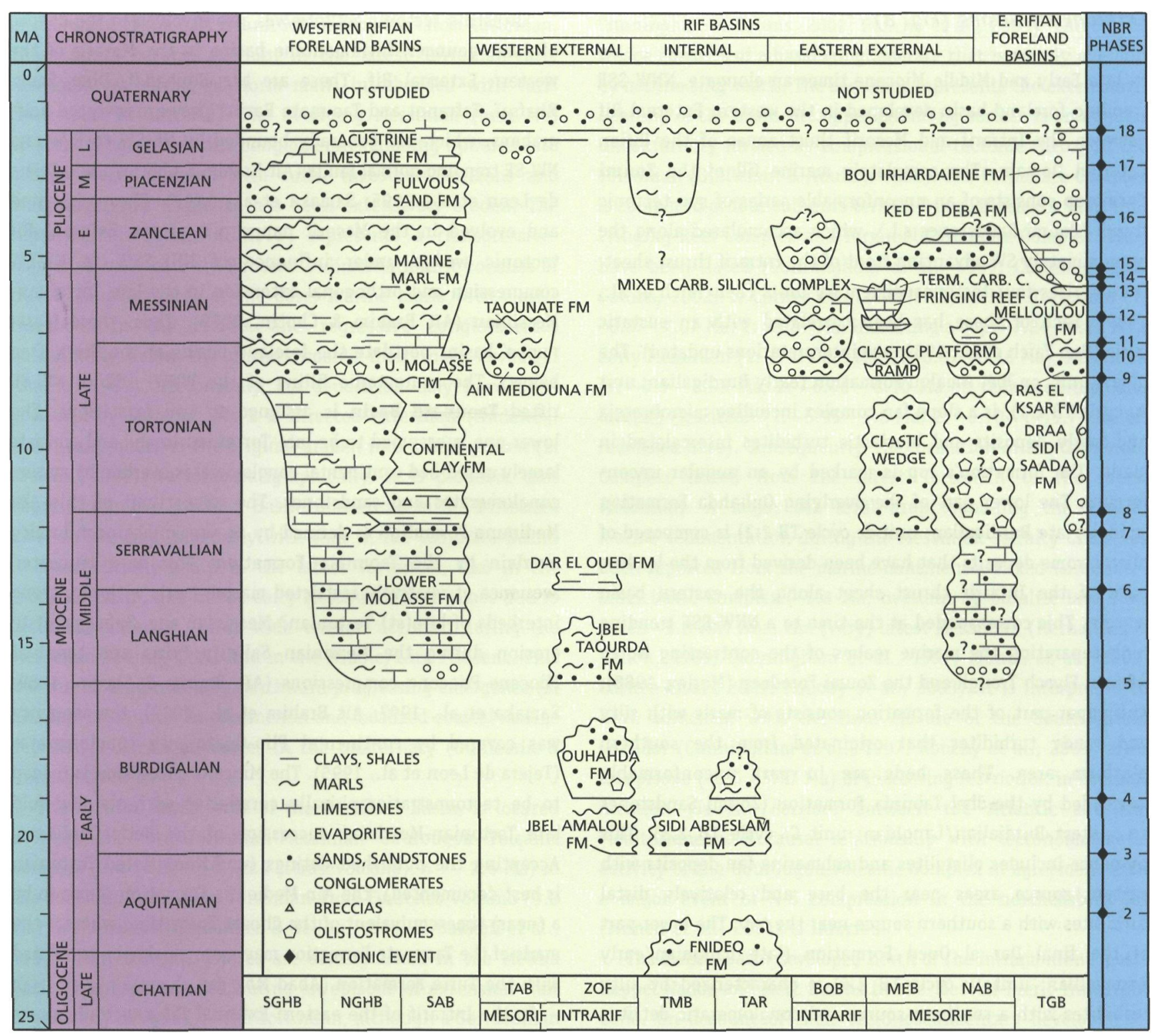

Fig. 8. Sequence stratigraphic diagram for internal, external and foreland basins of the Rif. BOB: Boudinar Basin, MEB: Melilla Basin, NAB: Nador Basin; NGHB: Northern Ghareb Basin, SAB: Saiss Basin, TAB: Taounate Basin, TAR: Talembote Region, TGB: Taza-Guercif Basin, TMB: Tetouan-Martil Basin, SGHB: Southern Gharb Basin, ZOF: Zoumi Foredeep.

three extensional phases: NE-SW to NNE-SSW rifting in the late Chattian, NW-SE to NNW-SSE extension during the Aquitanian and ENE-WSW to E-W extension in the early Burdigalian (Ouazani-Touhami \& Chalouan, 1995; Zaghloul et al., 2003). Accordingly, the stress field changed significantly at the Chattian-Aquitanian and Aquitanian-Burdigalian transitions. The Burdigalian beds of the Tetouan-Martil Basin are covered by a syn-rift accumulation of Pliocene sands and marls (Benmakhlouf \& Chalouan, 1995). In the southern Internal Rif the Ciudad Granada, Viñuela and Sidi Abdeslam Formations have been reported from the Talembote Region (Serrano et al., 2007) below an unnamed sequence of Early Miocene age (resp. formations SF. II (late Chattian-Aquitanian), SF. III (earliest Burdigalian), SF. IVa (at least early Burdigalian in part) and SF. IVb (Burdigalian p.p.) of El Kadiri et al., 2001). The formations constitute a chaotic sedimentary succession with olistolites and sedimentary klippes derived from the Ghomaride Complex (units FS. II-VIa) and the Dorsale Calcaire (unit SF. IVb). The contact of the 'Ciudad Granada' (Fnideq) and 'Viñuela' (Sidi Abdeslam) formations corresponds to a major ravinement surface (El Kadiri et al., 2001) that seems to have formed during the 'Aquitanian Paroxysm' as late Aquitanian strata are not known from the area. The sudden gravitational introduction of coarse Dorsale Calcaire detritus is assumed to be linked to the 'Burdigalian Paroxysm', i.e. the collision of the Rifian Internal and External Zones. 


\section{External Rif Basins (Fig. 8)}

In late Early and Middle Miocene times an elongate, NNW-SSE trending foreland basin developed in the western External Rif between the Intrarif and Mesorif thust zones of the Rifian External Domain. The completely marine fill of the Zoumi Foredeep consists of an unconformable series of syn-tectonic flysch (Zoumi Sandstones s.l.), which accumulated along the approximately SW advancing front of the Intrarif thrust sheet. It comprises four tectonosedimentary units (Ben Yaïch et al., 1989). Each of these has been correlated with an eustatic cycle (Ben Yaïch et al., 1989; age interpretations updated). The oldest unit, or Jbel Amalou Formation (early Burdigalian; unit A; cycle TB 2.1), is a slope fan complex including microbreccia and marly deposits and bioclastic turbidites intercalated in marls. The formation's top is marked by an angular unconformity. The lower part of the overlying Ouhahda Formation (middle/late Burdigalian; unit B; cycle TB 2.2) is composed of olistostrome deposits that have been derived from the leading edge of the Intrarif thrust sheet along the eastern basin margin. This corresponded at the time to a NNW-SSE trending high separating the marine realms of the contracting North African Flysch Trough and the Zoumi Foredeep (Morley, 1988). The upper part of the formation consists of marls with silty and sandy turbidites that originated from the southern platform area. These beds are in part unconformably succeeded by the Jbel Taourda Formation (Zoumi Sandstones s.s.; latest Burdialian/Langhian; unit C; cycle TB 2.3). This sequence includes olistolites and submarine fan deposits with eastern source areas near the base and relatively distal turbidites with a southern source near the top. The lower part of the final Dar el Oued Formation (late Langhian/early Serravallian; unit D; cycle TB 2.4) is characterized by silty turbidites with a southern source and conglomeratic detritus with an eastern source. The clayey upper subunit includes sandy turbidites near the base and an upper olistostrome deposit that was probably sourced again in the east (Ben Yaïch et al., 1989). It seems likely that the angular unconformity and olistostrome at the base of the Ouhahda Formation and the olistostrome at the base Jbel Taourda Formation represent enhanced tectonic activity in the Intrarif thrust zone subsequent to the onset of the 'Burdigalian Paroxysm' and the terminal Burdigalian closure of the North African Flysch Trough by E-W thrusting. Similarly, the sedimentary chaotic interval of the Dar el Oued Formation may be correlated with increased tectonic activity at the Intrarif thrust front at the beginning of Serravallian when the Kabylies collided with Africa (Vergés \& Sàbat, 1999). The Zoumi Foredeep itself was closed and destroyed in later Miocene times by incorporation of the basin(fill) in the leading edge of the WSW advancing Intrarif thrust sheet and subsequent out-of-sequence overthrusting of both tectonic features upon the Mesorif thrust zone (Morley, 1988).
Thrusting tectonic activity was also involved in the demise of some younger, intramontane basins in the Mesorif of the western External Rif. These are the Bouhaddi, Dhar Souk, Rhafsaï, Tafrannt and Taounate Basins They are inverted halfgrabens, which are generally bounded by NE-SW to E-W and NW-SE trending normal faults (Aï Brahim \& Chotin, 1989; Tejera de Leon et al., 1995; Samaka et al., 1997). They originated and evolved in the Mesorif nappe pile of the External Rif tectonic wedge under influence of NNE-SSW to NE-SW compression and orthogonal extension in the late TortonianMessinian (Aït Brahim \& Chotin, 1989). Thus, these 'postnappe' basins postdate the foreland basins of the Prerif (see below). The syntectonic filling of the WNW- ESE to NW-SE rifted Taounate Basin is assigned to two formations. The lower one is assumed to be late Tortonian in age and consists largely of red-bed continental conglomerates overlain by marine conglomerates and sandstones. The upper limit of this Ain Mediouna Formation is defined by an erosional unconformity overlain by the Taounate Formation. This is a truncated sequence of relatively restricted marine marls with sandstone interbeds of late(st) Tortonian?-Messinian age. Subsequent to erosion during the Messinian Salinity Crisis and terminal Miocene-Pliocene compressions (Aït Brahim \& Chotin, 1989; Samaka et al., 1997; Aït Brahim et al., 2002), the sequence was covered by continental Plio-Quaternary conglomerates (Tejera de Leon et al., 1995). The Miocene succession is judged to be tectonostratigraphically correlative with the two-fold late Tortonian-Messinian succession of the Betic Cordillera. Accepting the published datings (undifferentiated Tortonian is best documented), the Aïn Mediouna Formation seems to be a (near) time-equivalent of the Chozas Formation, whereas the marls of the Taounate Formation may more reliably be correlated with the Turre Formation (Abad Mb.; see above).

In the Intrarif of the eastern External Rif a tectonic stress regime basically similar to the one leading to the Taounate Basin resulted in the Boudinar Basin. This triangular strikeslip basin is bordered in the east by the sinistral Nekor strikeslip fault (Leblanc, 1980; Asebryi et al., 1993) and flanked by a dextral slike-slip fault system that delimits the andesitic Ras Tarf volcano of Serravallian-Messinian age ( 12.5 - 13 to 6 - $7 \mathrm{Ma}$; El Kharim, 1991; El Bakkali et al., 1998) in the west (Guillemin \& Houzay, 1982; El Kharim, 1991). In the late Tortonian the intramontane basin opened by $\mathrm{E}-\mathrm{W}$ extension in association with orthogonal compression (Aït Brahim \& Chotin, 1990) as a 'post-nappe' graben-like structure. Four unconformity-bounded basin fill units are generally distinguished (units M1 to M3 and $P$ of El Kharim, 1991). Firstly, continental and lagoonalmarine deposits, represented by proximal red conglomerates and distal sands and grey marls with tuff, accumulated discordantly (unit M1). Locally at least, this transgresssive, overall alluvial fan-coastal marine sequence is truncated by an angular unconformity. It is succeeded by coarse, syn-tectonic fan conglomerates (and sands) laid down in a coastal marine 
environment (basal part of unit M2) during the latest Tortonian. These strata became overlain in the latest Tortonian-early Messinian by marine platform marls interbedded with tuffs (main part of unit M2). The overlying Messinian (unit M3) consists of coastal marine conglomerates grading upwards into marine platform marls with tuffs, limestone horizons and diatomites. This sequence has been extensively eroded. The suprajacent sequence (unit $\mathrm{P}$ ) represents a transgressiveregressive cycle of Early Pliocene sedimentation. It consists of fluvial conglomerates at the base, marine marls with clastic interbeds in the middle and regressive conglomerates immediately below the unconformable Quaternary cover (El Kharim, 1991). Tectonically, its deposition may have been governed by more or less E-W directed extension (Andeweg, 2002) that modified the original graben into a half-graben (El Kharim, 1991). tectonostratigraphically, it is probable that deposition in the Boudinar Basin commenced in the Tortonian more or less simultaneously with that in the Taounate Basin. It ceased briefly again in the latest Tortonian, like in the Taounate Basin, and in the early Messinian: both times due to tectonics. Later on, basin-wide erosion occurred during the Messinian Salinity Crisis and in the Middle/Late Pliocene. This was due to longitudinally northward progressing emergence (El Kharim, 1991) prior to continental and localized coastal marine deposition of conglomerates in the Quaternary (Guillemin \& Houzay, 1982).

The Melilla Basin, east of the Boudinar Basin, is located between the late Tortonian-Messinian Gourougou Volcanic Complex (9.0 - 6.6, 7.0 - 5.4 (stratovolcano), $4.7-2.6 \mathrm{Ma}$ ) in the south and the early Tortonian Trois Fourches Volcano (9.8 Ma) in the north (Hernandez \& Bellon, 1985; El Bakkali et al., 1998). Four tectonic phases are distinguished in the Melilla Basin. The basin opened during an episode of extension that is generally assigned to the Tortonian, although a Serravallian age is possible. The initial rifting is followed by a Tortonian phase of N-S compression, a latest Tortonian-Messinian period of NE-SW extension and a final phase of NW-SE compression initiated in the (Late?) Pliocene (Guillemin \& Houzay, 1982). The fill of this intramontane, roughly E-W striking strike-slip basin consists of a stack of four main sequences with three subsequences which are separated by proximal and basinwide erosional surfaces. The main sequences consist of a Clastic Wedge of early Serravallian?-Tortonian age (conceptual age; cf. Leblanc, 1980), a shallow-marine Carbonate Complex of Tortonian-Messinian age and an overlying Mixed CarbonateSiliciclastic Complex of late Messinian age that accumulated conformably under marine and lacustrine conditions without significant evaporites. This Mixed Carbonate-Siliciclastic Complex is unconformably overlain by sandy marine Pliocene that locally fills a deeply incised erosion surface that represents a terminal Messinian period ( $<5.77 \mathrm{Ma}$ ) of sub-aerial exposure with intense erosion prior to the onset of the diachronous marine drowning of the palaeotopography $(\sim(<) 5.3 \mathrm{Ma}$; Cunningham et al., 1997;
Cunningham \& Collins, 2002; Rouchy et al., 2003). The Clastic Wedge consists of a basal conglomerate that is mainly overlain by marine silty marls. The sequence represents the extensional opening of the basin. Its upper bounding surface is an angular unconformity formed by compressional tectonic tilting in the Tortonian (Guillemin \& Houzay, 1982). The Carbonate Complex is composed of four subunits termed Ramp, Bioclastic Platform, Fringing-Reef Complex and Terminal Carbonate Complex. They have been dated (Cunningham et al., 1997; Cunningham \& Collins, 2002: 1; Cornée et al., 2002: 2) as late Tortonian (1: $\sim 8.8$ ? - 7.07 Ma; 2: >6.87 Ma; indicating a gap: >7.24 - 6.87 Ma), early Messinian (1: 7.0 - 6.3 Ma; 2: 6.87 - 6.46 Ma), Messinian (1: $\sim 6.3-5.95 \mathrm{Ma} ; 2: \sim 6.46-6.10 \mathrm{Ma} c \mathrm{cf}$. redefined top) and late(st) Messinian (1: $\sim 5.95$ - $5.8 \mathrm{Ma} ; 2: \sim 6.10$ - (<)5.77 Ma cf. redefined base). Consequently, the formation of the Carbonate Complex lasted from the latest Tortonian to the latest Messinian. A major sea level drop signalling the end of marine sedimentation during the Messinian Salinity Crisis has been reported from the marine-continental Mixed CarbonateSiliciclastic Complex.( 5.8 Ma; overlain by basaltic lava flow dated $\sim 5.8 \mathrm{Ma}$ ) from the (very) latest Messinian (Hernandez \& Bellon, 1985; Cunningham et al., 1997; Münch et al., 2001; Cornée et al., 2002; Rouchy et al., 2003). It is interpreted to have coincided with the final closure of the South Rifian Corridor (Cunningham et al., 1997; Rouchy et al., 2003) after an episode ( 6.5 - 5.77 Ma) of increasing restriction in communication via the corridor between the Atlantic and the Mediterranean. A causal relationship with tectonomagmatic activity of the Gourougou Volcanic Complex in agreement with a major event of N-S compression in the northeastern Rif (Münch et al., 2001) is inferred.

The Melilla Basin developed north of the intramontane 'postnappe' Nador and Kert Basins in the Mesorif-Prerif transition zone. On account of their tectonosedimentary development, the southern sectors of these basins may be conceived as marginal parts of the Eastern Prerif Foreland Basin. The Nador Basin is bordered in the west by the Gourougou Volcanic Complex. The overall marine fill of the WSW-ENE striking 'pullapart basin' (Chotin \& Ait Brahim, 1988; Ait Brahim \& Chotin, 1990) comprises four cyclically deposited sequences. They accumulated on top of a pre-Tertiary substratum or a Middle Miocene sequence of conglomerates and sandy limestones, which is interpreted to have been formed in a 'foredeep' that made part of the Prerif Foreland Basin and Proto-South Rifian Corridor. The oldest overlying cycle includes an olistostrome that rests unconformably to conformably upon a SW-vergent complex of imbricates and thrust sheets of Mesozoic and Middle Miocene rocks formed by concurrent NE-SW compression and gravitation (de Luca, 1985; Yahyaoui et al., 1997). In turn, the chaotic unit, which contains detritus up to Middle Miocene age, is conformably overlain by northward prograding, coarsegrained clastics which grade upwards into sandy and gypsiferous marls. Tentatively, the entire formation is 
sequence stratigraphically attributed to the late Serravallian?early/middle Tortonian (see below), although the olistostrome has not been dated and may be visualized as a separate (sub)sequence formed in response to compressional uplifting of the nearby Gareb, Kebdana and Beni Bou Ifrour massifs (de Luca, 1985; Ait Brahim, 1985). This sequence is unconformably overlain by a series of 'post-nappe' deposits starting with a comparatively thin sequence of red-coloured conglomerates, sandstones and marls, which is truncated by an angular unconformity (Aït Brahim, 1985; de Luca, 1985; Yahyaoui et al., 1997). The syn-rift, fluvial to marine sequence has been attributed to the late Tortonian, assuming that uppermost Tortonian strata are absent due to NE-SW compression inducing thrusting, uplift and erosion of the basin fill (Aït Brahim, 1985; Yahyaoui et al., 1997). Messinian strata transgressed both Tortonian sequences during resumed WSW-ENE extension and subsidence of the basin. The resultant sequence comprises calcarenitic and reefal limestones, which are interbedded, laterally replaced or succeeded by fossiliferous marls with sandstone and tuff horizons. Shallow-marine sandy conglomerates occur at the base of the sequence. Reliably dated, late Messinian strata are unknown. The unconformably overlying Lower Pliocene includes mainly shallow-marine sands and lacustrine limestones (Guillemin \& Houzay, 1982; de Luca, 1985; Yahyaoui et al., 1997).

\section{Eastern Rifian Foreland Basins (Fig. 8)}

Chaotic mass-flow deposits (olistostromes, sedimentary klippes) like those encountered in the Nador Basin are found throughout the External Rif. In particular, they occur at the uprooted nappe system of the Prerif thrust zone forming the Tortonian tectonosedimentary complex of overthrusting, diverticulate gliding nappes, or Prerif Allochthon (Frizon de Lamotte, 1987; Flinch, 1996; Pratsch, 1996; Chalouan et al., 2001). The emplacement of this major allochthonous unit occurred in the Moroccan Foreland, which includes this huge accretionary wedge, the Gharb and Saiss Basins in the west (see below) and the Taza-Guercif Basin and some smaller extensional basins in the east. The Taza-Guercif Basin is superimposed on the northeastern plunge of the NE-SW striking Middle Atlas. The basin is a similarly trending graben system that developed in response to NW-SE extension in the Tortonian, coevally with transport of thrust sheets of the adjoining Rif to the west and southwest. After the Tortonian, it was subjected to NW-SE to NNW-SSE directed contractional tectonics. The contraction occurred contemporaneously with similarly oriented thrusting in the Rif, leading to synsedimentary basin inversion in line with sinistral transpressive activity of the Middle Atlas Shear Zone that was in turn related to the NW-SE to N-S convergence of Africa and Europe. The intra-Messinian initiation of S-vergent thrusting coincided with the end of extension and the beginning of contractional transformation of the basin into an intramontane basin with subsidence that would no longer be controlled by tectonics but instead by sediment loading (Bernini et al., 2000; Gomez et al., 2000; Sani et al., 2000). Though belonging to the system of Rifian foreland basins, the Taza-Guercif Basin was not really part of the South Rifian Corridor, neither structurally nor palaeogeographically. The basin opened in the late Serravallian (cf. Leblanc, 1980) or early Tortonian (Gomez et al., 2000) Five, partly unconformable main sequences developed with boundaries related to tectonic events (Bernini et al., 1999; Gelati et al., 2000). This gave rise to three unconformitybounded successions with major erosional hiatuses that represent distinct deformation events (Gelati et al., 2000; Gomez et al., 2000; Sani et al., 2000). Basin infilling began with the syn-rift Draa Sidi Saada Formation, a sequence that comprises sandy conglomerates, breccia and red-coloured, sandy to silty marls of presumably Serravallian?-early/middle Tortonian age (> 8 Ma; Krijgsman et al., 1999b; Gomez et al., 2000). The formation and nearby basement are unconformably transgressed by the syn-rift Ras el Ksar Formation, like. The stratigraphic contact of the Draa Sidi Saada and Ras el Ksar Formations corresponds to an episode of compressional tectonics. The latter rock-unit consists of sandy conglomerates, sandstones, marls and bioclastic strata deposited in a transitional continental-marine environment. The sudden and probably synchronous onset of the transgression coincides with the initiation of shoshonitic volcanism (8 - $4.9 \mathrm{Ma}$; Hernandez \& Bellon, 1985). It is interpreted to mark the late Tortonian opening of the South Rifian Corridor ( 8 Ma; Krijgsman et al., 1999b) as a foredeep formed by NNW-SSE compression of the pre-existing Proto-South Rifian Corridor due to the NNW-SSE/N-S convergence of Africa and Iberia. This momentous event was preceded by the deposition of a thick, Tortonian (and older?) sequence of marine strata which could be a correlative of the continental Draa Sidi Saada Formation. Overall, the Taza-Guercif Basin became part of the Proto-South Rifian Corridor in the Tortonian.

The lower/middle Tortonian is conformably overlain by the open-marine Melloulou Formation, formed under quiescent tectonic conditions. It is divided into the Blue Marls, El Rhirane and Tachrift Turbidites and Gypsiferous Marls subunits. The unconformity-bounded 'Tortonian Succession' is actually late Tortonian-early Messinian in age (Gomez et al., 2000). The turbidite sedimentation reflects contemporaneous uplifting of the basin margin area. This was associated with tectonic re-activation of the Middle Atlas Shear Zone, whereas the great thicknesses of the gradually regressive gypsiferous marls indicate that strong foreland subsidence continued until early (pre-evaporitic) Messinian time (Gelati et al., 2000). This was concurrent with a shallowing of both the basin and the South Rifian Corridor just after the Tortonian-Messinian transition (between 7.2 and $7.1 \mathrm{Ma}$ ) and an increasing compressional constriction of the corridor (Bernini et al., 1999; Krijgsman et 
al., 1999b; Gomez et al., 2000). The next unconformity-bounded unit is the post-rift 'Messinian Succession', which includes the sandy and marly beds of the episodic continental and marine Kef ed Deba Formation (Gelati et al., 2000) of early (still preevaporitic) Messinian age (Krijgsman et al., 1999b). Its basal angular unconformity marks emergence of the basin that may be related to continued southward advance of the External Rif in association with further narrowing of the South Rifian Corridor west of the basin (Bernini et al., 1999). The pronounced angular unconformity at the top probably correlates with the definitive closure of the corridor by continued thin-skinned overthrusting of the External Rif. The accretionary Prerif Allochthon was thrust over the Middle Atlas in the region between the Sais Basin and the Taza-Guercif Basin (between $\sim 6.7$ and 6.0 Ma; Krijgsman et al., 1999b), while transpressional tectonics of the Middle Atlas Shear Zone also continued to affect the basin. Consequently, the trans-Moroccan seaway allowing marine communication between the Atlantic and Mediterranean was permanently closed (by partial emergence) just before the onset of the Messinian Salinity Crisis (5.96 Ma). Correspondingly, the successive late Messinian, Pliocene and Quaternary deposits are all fully continental. They comprise the fluvial conglomerates and the lacustrine limestones and mudstones of the Bou Irhardaiene Formation, or 'Plio-Quaternary Succession'. Their deposition occurred in a contracting, landlocked basin, the filling of which was governed by sediment input from uplifted adjoining highs that continued to be affected by transpression (Bernini et al., 1999, 2000; Gelati et al., 2000; Gomez et al., 2000; Sani et al., 2000).

\section{Western Rifian Foreland Basins (Fig. 8)}

The eastern sector of the Western Prerif Foreland Basin corresponds to the Saiss Basin, a post-Burdigalian foredeep bordered by the Prerif Allochthon in the north and the Atlasic Moroccan Meseta (Foreland) in the south. In the west the basin merges with the Gharb Basin (see below). As part of the South Rifian Corridor, it communicated in late Tortonian-early Messinian times with the Taza-Guercif Basin. Provisionally, six formational sequences are distinguished in the area (cf. Aït Brahim \& Chotin, 1984), constituting two major transgressiveregressive sedimentary series. An older 'ante-nappe' series composed of Langhian to Tortonian deposits and a younger 'post-nappe' series consisting of late Tortonian to PlioQuaternary formations. The older one consists of the basal conglomerates and shallow-marine limestones of the Lower Molasse Formation, which during the Langhian-early Serravallian trangressed a Mesozoic substratum. At the same time, flexuralisostatic bending of the Moroccan Foreland lithosphere into the Proto-South Rifian Foreland Basin took place in front of the nascent Rif prism. The Lower Molasse accumulated in the Proto-South Rifian Corridor until the marine seaway was abruptly disrupted in the area of the Saiss Basin by the deposition of freshwater carbonates, red and green clays and sandstones of the late Serravallian-early/middle Tortonian Continental Clay Formation. Presumably, the marine deposition came suddenly to an end in response to a late Serravallian phase of compressional tectonics that blocked off this part of the marine Prerif Foreland Basin and Proto-South Rifian Corridor by deposition of mainly continental clays derived from the adjoining, low-relief Moroccan Foreland. The continental formation includes a brecciated deposit of marly limestones, the base of which correlates with the Serravallian-Tortonia transition (Aït Brahim \& Chotin, 1984). The overlying series consists of three unconformity-bounded sequences. The lower one, or Upper Molasse Formation, includes mega-breccias overlain by sandy bioclastic limestones and white marls of late Tortonian age. It marks the transgressive re-opening of the marine South Rifian Corridor and the 'post-nappe' formation of the Saiss Basin proper by renewed foredeep flexuring of Moroccan Foreland related to further westward thrust transport and loading of the Prerif Allochthon. The unconformably overlying Marine Marl Formation is composed of sandy and marly limestones grading upwards into white, grey and blue marls. Its age ranges from latest Tortonian to Early Pliocene. The uppermost, unconformity-bounded sequence comprises the marine and fluviatile, variously coloured clastics of the Fulvous Sand Formation and the bioclastic Lacustrine Limestone Formation, which comprises also fluviatile carbonates and travertine. Jointly, the respectively Early-Middle Pliocene and Late Pliocene-Quaternary formations form a trangressiveregressive cycle. That cycle was initiated by a marine ingression from the Atlantic and concluded by an episode of tectonic emergence and continentalisation. This resulted in a progressive shrinking of the Saiss Basin in combination with an anti-clockwise rotation of compression trends that caused re-activation of (strike-slip) faults and syn-sedimentary extensional and compressional deformation of the PlioQuaternary fill (Ahmamou \& Chalouan, 1988; Ait Brahim \& Chotin, 1984, 1989).

The sedimentary development of the Gharb Basin, located near the Atlantic coast and extending offshore, underwent major foredeep subsidence and deposition of great thicknesses of clastic basin fill. Three principal sequences of Neogene age are distinguished in the Northern Gharb Basin: a basal Miocene sequence, an overlying Late Miocene olistostrome that is part of the Prerif Allochthon, and a cover sequence of Late Miocene and Plio-Quaternary age (Flinch, 1996; Pratsch, 1996). The basal Miocene sequence consists of Langhian-Serravallian and Tortonian marls and limestones (Flinch, 1996), which accumulated during a compressional tectonic regime founding the western Prerif foredeep (Litto et al., 2001). On account of comparisons with the Saiss Basin (see above), it is surmised that coeval, partly calcareous strata have been laid down in the Southern Gharb Basin, similarly onlapping the Moroccan Foreland. The olistostrome is interpreted to be an 
unconformable, gravity-driven sedimentary unit that slid southward into the Western Prerif Foreland Basin, simultaneously with late Tortonian thrust loading of the adjoining External Rif and subsidence of Moroccan Foreland, carrying olistolites derived from tectonically-deformed and uplifted parts of the emergent External Rif (Pratsch, 1996). The overlying transgressive-regressive sequence is equivalent to the Marine Marl Formation of the Saiss Basin (Akrech Sequence of Barbieri $\&$ Ori, 2000). Its marine marls with turbidite sandstones reflect enhanced basin subsidence that was, most of all, controlled by rapid extensional collapse of the accretionary wedge in the late Tortonian-Messinian (Flinch, 1996). In early Zanclean time deposition of deep-water clastics probably coincided with a marine transgression from the Atlantic and continued syn-sedimentary extensional tectonics (Litto et al., 2001). A number of relative sea-level drops attributable to tectonic uplifts have been recognized at the southern margin of the Gharb Basin. These range in age from the first shallowing related to the final closure of the South Rifian Corridor to events at the beginning and end of the Messinian Salinity Crisis (resp. $7.3 \mathrm{Ma}$ and $\sim 6.5 \mathrm{Ma} ; \sim 6 \mathrm{Ma}, \sim 5.3 \mathrm{Ma}$ and $\sim 5.4 \mathrm{Ma}$; Barbieri \& 0ri, 2000; Warny et al., 2003). These brief pulses of apparent compression occurred before the establishment of a continuum of compressional deformation in the Pliocene and Quaternary (Litto et al., 2001). The upward coarsening trend noted in the sandy marls of the late Zanclean (Mamora Sequence of Barbieri \& 0ri., 2000) reflects a marine regression that was a prelude to the emergence of the southern part of the Gharb Basin at the onset of the probably unconformable deposition of the marine Fulvous sands. The sharply transgressive and unconformably overlying Zanclean-Piacenzian and Gelasian? strata (Zemmour Sequence of Barbieri \& Ori, 2000), which are covered by Pliocene?-Quaternary continental conglomerates, represent an episode of shallow-marine to lacustrine deposition. Its regressive accumulation was probably controlled by compressional deformation and reduced subsidence of the basin, as well as by regional tectonic uplift (Barbieri \& 0ri, 2000). Most likely, it occurred in tandem with that of the Fulvous Sand-Lacustrine Limestone succession in the Saiss Basin.

\section{Conclusion}

Overall, the tectonostratigraphic evolution of the Betic-Rif orocline was governed by a temporal succession of tectonic regimes and stratigraphic events that was primarily linked to deep-seated crustal processes associated with the slow and ongoing N-S convergence of the African and Iberian plates and secondly to the intermediate $\mathrm{E}-\mathrm{W}$ migration of Alboran. Based on the repeated occurrence of tectonically-induced sequence boundaries (unconformities) of basin fills, the convergence of Africa and Iberia is interpreted to have been affected time and again, by brief episodes of enhanced tectonics and plate-kinematic change during their convergent movement, either in terms of migratory direction or collisional force. At present, the general (first-order) relative motion between the African and European plates during the Alpine orogeny is fairly well known for the Neogene (e.g. Dewey et al., 1989; Rosenbaum et al., 2002). However, the precise (second-order) direction and rate of the motion of Africa relative to Iberia is not yet known. Whatever their precise origin, changes in plate motion had a widespread, albeit varied effect upon the numerous Neogene basins of the Betic-Rif orocline. Thus, preexisting basins were, wholesale or in part, tectonically modified and temporarily or permanently closed by tectonic uplift, whereas new basins originated by tectonic subsidence. The resulting tectonostratigraphic regime of punctuated deposition and non-deposition/erosion did not only affect the development of the Betic basins (e.g. Sanz de Galdeano \& Vera, 1991, 1992) but had also a very similar effect on the depositional history of the Rif basins. The depositional episodicity of the Betic and Rif basins is judged to be tectonostratigraphically correlative, both encompassing a large number of (essentially) coeval Neogene Betic-Rif (NBR) phases, This forms a general interpretative model for the tectonostratigraphy of the entire region (Fig. 9). Moreover, the temporal sequence of these tectonics-related phases are strikingly correlative with the similarly defined succession of Cenozoic Rift and Foreland (CRF) phases which determined to a large extent the Neogene depositional development of the basins elsewhere in southern and western Europe (Fig. 9; Sissingh, 2006). Consequently, it is suggested that the polyphase histories of deposition of all these basins were basically closely linked through a causal network recording widespread changes of intra-plate tectonic-stress regimes. Their upper crustal development in time reflects effective modifications of the plate-kinematic regime linked to the northward motion of Africa relative to Europe. The striking time-correlation of the different polyphase tectonostratigraphic zonations and scenarios of the basins located in the Betic-Rif, western Mediterranean and Alpine foreland regions supports the concept that the large-scale convergence of Africa relative to Europe has over time varied more in direction and force (rate) than is presently appreciated. In other words, the punctuated (polyphase) sedimentary infilling in combination with the tectonic basin evolution of these regions in general records a causal relationship with changes in geodynamic activity at the European-African plate-boundary zone. The palaeogeographic evolution of the region of the Betic-Rif orocline was governed by the same basic processes which controlled the tectonostratigraphy of the area. Surely, the role of global fluctuations of sea level was important at times, but of secondary sinificance in a more general sense: quite simply, tectonics dominated over eustacy in the Betic-Rif region. From its initial development, the Betic-Rif orocline remained under collisional stress due to the ongoing $\mathrm{N}-\mathrm{S}$ convergent motion of Africa and 
Iberia. In response to the induced tectonics, extensional and compressional basins evolved during the Neogene structurally as well as palaeogeographically in a tectonically complex setting. In a regionally single stress field with local variations syn-kinematic sedimentary sequences accumulated in basins that developed in parallel episodically and coevally. Apparently,

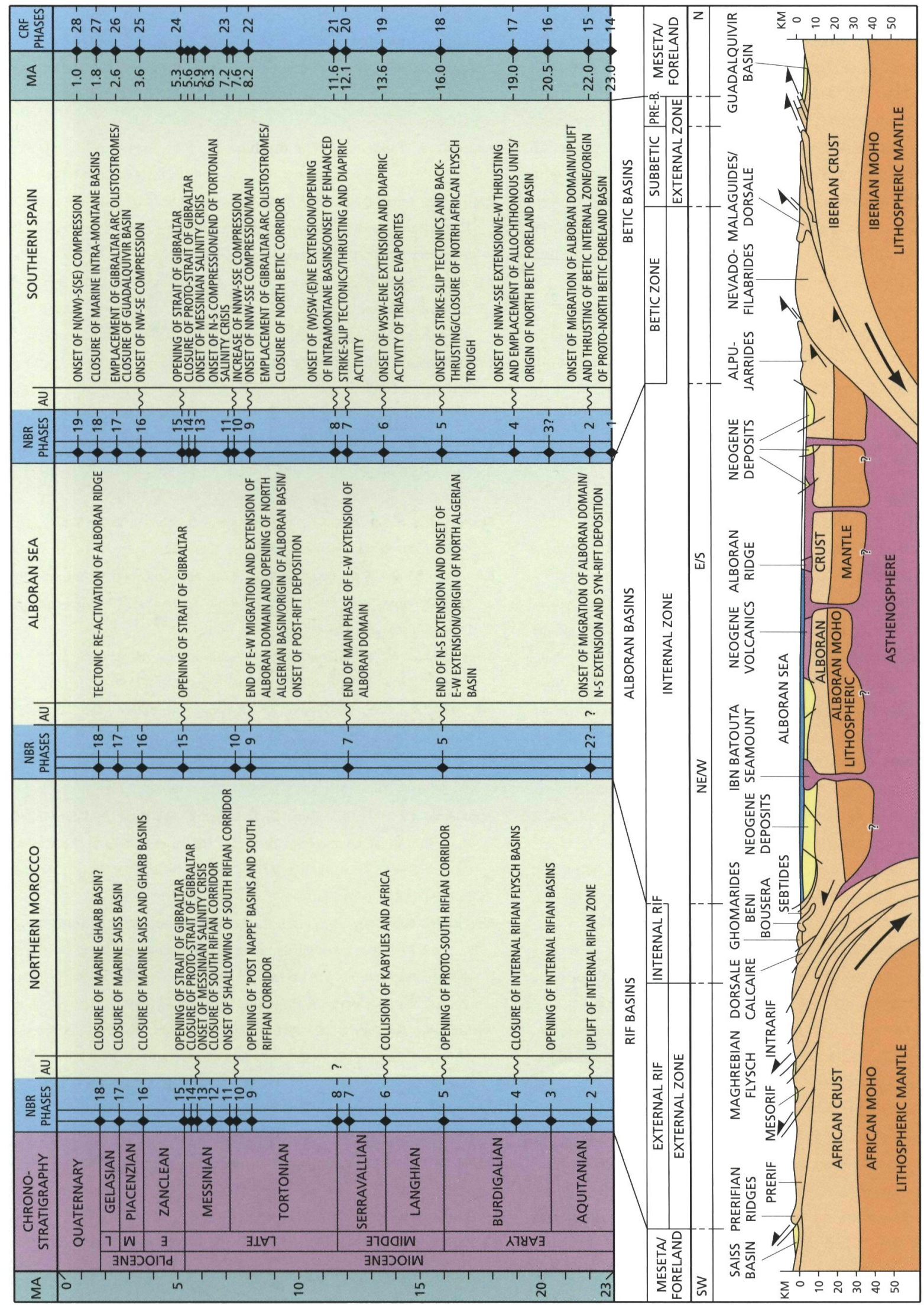

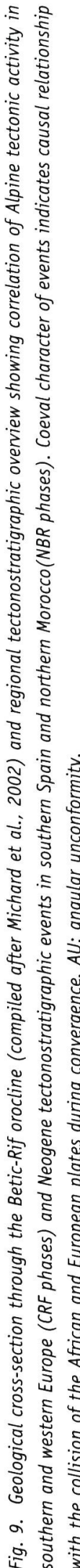


regionally coeval developments occurred in a current manner, meaning causal chains of broadly simultaneous and linked geological events governed the tectonostratigraphic evolution of the Betic-Rif orocline as a whole. Through the Neogene, marine communication occurred between the Atlantic and Mediterranean basins (Appendices 1 - 7). Influenced by glacioeustatic changes in sea level and episodic influxes of marine water from the Atlantic, the progressive isolation and continentalisation of the Mediterranean during the Messinian was primarily driven by ongoing compressional tectonics in the area of the present Strait of Gibraltar. Both the onset and termination of the Messinian Salinity Crisis were tectonicallyinduced; principally in a causal relationship with compressional thickening and uplifting of oroclinal upper crust in the region of the Strait of Gibraltar (cf. Rouchy \& Caruso, 2006).

\section{Acknowledgements}

The author is indedted to P.A. Ziegler (Basel) and E. van de Graaff (Rijswijk) for their constructive comments and careful review of an early draft of this paper.

\section{References}

Aellen-de La Chapelle, M., 1990. Le couloir de Pulpi. Documents et Travaux de I'IGAL 12-13: 195-206.

Aguirre, J. \& Sánchez-Almazo, I.M., 2004. The Messinian post-evaporitic deposits of the Gafares area (Almería-Níjar basin, SE Spain). A new view of the 'Lago-Mare' facies. Sedimentary Geology 168: 71-95.

Ahmamou, M. \& Chalouan, A., 1988. Distension synsédimentaire plioquaternaire et rotation anti-horaire des contraintes au Quaternaire ancien sur la bordure nord du bassin du Saïss (Maroc). Bulletin de l'Institut Scientifique (Rabat) 12: 19-26.

Aït Brahim, L., 1985. Migration des aires de subsidence maximum et réorientation de la direction du champ de contrainte dans les bassins néogènes du Maroc septentrional. Bulletin de l'Institut Scientifique (Rabat) 9: 89-96.

Aït Brahim, L., 1986. La zone de fracture trans-marocaine Agadir-Nekor: criterès géophysiques, données de terrain et analyse de documents Landsat. Bulletin de l'Institut Sceintifique (Rabat) 10: 27-40.

Ait Brahim, L. \& Chotin, P., 1984. Mise en évidence d'un changement de direction de compression dans l'avant-pays rifain (Maroc) au cours du Tertiaire et du Quaternaire. Bulletin de la Société Géologique de France 7, 26: 681-691.

Aït Brahim, L. \& Chotin, P., 1989. Genèse et déformation des bassins néogènes du Rif central (Maroc) au cours du rapprochement Europe-Afrique. Geodinamica Acta 3: 295-304.

Aït Brahim, L. \& Chotin, P., 1990. Oriental Moroccan Neogene volcanism and strike-slip faulting. Journal of African Earth Scieinces 11: 273-280.

Aït Brahim, L., Chotin, P., Hinaj, S., Abdelouafi, A., El Adraoui, A., Nakcha, C., Dhont, D., Charroud, M., Sossey Aloui, F., Amrhar, M., Bouaza, A., Tabyaoui, H. \& Chaouni, A., 2002. Paleostress evolution in the Moroccan African margin from Triassic to Present. Tectonophysics 357: 187-205.
Alfaro, P., Delgado, J., Estévez, A., Soria, J.M. \& Yébenes, A., 2002. Onshore and offshore compressional tectonics in the eastern Betic Cordillera (SE Spain). Marine Geology 186: 337-349.

Allerton, S., Lonergan, L., Platt, J.P., Platzman, E.S. \& McClelland, E., 1993. Palaeomagnetic rotations in the eastern Betic Cordillera, southern Spain. Earth and Planetary Science Letters 119: 225-241.

Andeweg, B., 2002. Cenozoic Tectonic Evolution of the Iberian Peninsula: Causes and Effects of Changing Stress Fields. Ph.D. Thesis, Free Univ. (Amsterdam): $178 \mathrm{pp}$.

Andrieux, J., Fontboté, J.-M. \& Mattauer, M., 1971. Sur un modèle explicatif de l'arc de Gibraltar. Earth and Planetary Science Letters 12: 191-198.

Argus, D.F., Gordon, R.G., DeMets, C. \& Stein, S., 1989. Closure of the AfricaEurasia-North America plate motion circuit and tectonics of the Gloria fault. Journal of Geophysical Research B 94: 5585-5602.

Asebriy, L., Bourgois, J., Cherkaoui, T.E. \& Azdimousa, A., 1993. Evolution tectonique récente de la zone de faille du Nékor: importance paléogéographique et structurale dans le Rif externe, Maroc. Journal of African Earth Sciences 17: 65-74.

Atunes, M.T. \& Pais, J., 1993. The Neogene of Portugal. Ciências da Terra (UNL) 12: 7-22.

Balanyá, J.C. \& Garcia-Dueñas, 1987. Les directions structurales dans le Domaine d'Alborán de part et d'autre du Détroit de Gibraltar. Comptes Rendus de l'Académie des Sciences (Paris) 2, 304: 929-932.

Banks, C.J. \& Warburton, J., 1991. Mid-crustal detachment in the Betic system of southeast Spain. Tectonophysics 191: 275-289.

Barbieri, R. \& Ori, G.G., 2000. Neogene palaeoenvironmental evolution in the Atlantic side of the Rifian Corridor (Morocco). Palaeogeography, Palaeoclimatology, Palaeoecology 163: 1-31.

Benmakhlouf, M. \& Chalouan, A., 1995. Evolution néogène du bassin de Tétouan-Martil, Rif septentrional, Maroc. Geogaceta 17: 98-100.

Ben Yaïch, A., Duée, G., Souquet, P., \& Fondecave-Wallez, M.-J., 1989. Les Grès de Zoumi: dépôts turbiditiques d'une avant-fosse miocène (BurdigalienSerravallien) dans le Rif occidental (Maroc). Comptes Rendus de l'Académie des Sciences (Paris) 2, 309: 1819-1825.

Berástegui, X., Banks, C.J., Puig, C., Taberner, C., Waltham, D. \& Fernández, $\boldsymbol{M} .$, 1998. Lateral diapiric emplacement of Triassic evaporites at the southen margin of the Guadalquivir Basin, Spain. Geological Society Special Publication (London) 134: 49-68.

Bernini, M., Boccaletti, M., Gelati, R., Moratti, G., Papani, P. \& El Mokhtari, J., 1999. Tectonics and sedimentation in the Taza-Guercif Basin, northern Morocco: implications for the Neogene evolution of the Rif-Middle Atlas orogenic system. Journal of Petroleum Geology 22: 115-128.

Bernini, M., Boccaletti, M., Moratti, G. \& Papani, G., 2000. Structural development of the Taza-Guercif Basin as a constraint for the Middle Atlas Shear Zone tectonic evolution. Marine and Petroleum Geology 17: 391-408.

Biermann, C., 1995. The Betic Cordilleras (SE Spain). Anatomy of a dualistic collision-type orogenic belt. Geologie en Mijnbouw 74: 167-182.

Blanco, M.J. \& Spakman, W., 1993. The P-wave velocity structure of the mantle below the Iberian Peninsula: evidence for subducted lithosphere below southern Spain. Tectonophysics 221: 13-34. 
Bocalletti, M., Gelati, R., Papani, G., Bernini, M., El Mokhtari, J. \& Moratti, G., 1990. The Gibraltar Arc: an example of Neoalpine arcuate deformation connected with ensialic shear zones. Memorie della Societa Geologica Italiana 45: 409-423.

Boorsma, L.J., 1993. Syn-tectonic Sedimentation in a Neogene Strike-slip Basin (Serrata area, SE Spain). Ph.D. Thesis, Univ. Amsterdam (Amsterdam): 85 pp.

Bordet, P., 1985. Le Volcanisme Miocène des Sierras de Gata et de Carboneras (Espagne de Sud-Est). Documents et Travaux de l'IGAL 8: $70 \mathrm{pp.}$

Braga, J.C. \& Martín, J.M., 1996. Geometries of reef advance in response to relative sea-level changes in a Messinian (uppermost Miocene) fringing reef (Cariatiz reef, Sorbas Basin, SE Spain). Sedimentary Geology 107: 61-81.

Braga, J.C., Martín, J.M. \& Quesada, C., 2003. Patterns and average rates of late Neogene-Recent uplift of the Betic Cordillera, SE Spain. Geomorphology 50: 3-26.

Briend, M., Montenat, C. \& Ott d'Estevou, P., 1990. Le bassin de Huercal-0vera. Documents et Travaux de l'IGAL 12-13: 239-259.

Buforn, E., Udías, A. \& Colombás, M.A., 1988. Seismicity, source mechanisms and tectonics of the Azores-Gibraltar plate boundary. Tectonophysics 152: 89-118.

Buforn, E., Sanz de Galdeano, C. \& Udias, A., 1995. Seismotectonics of the Ibero-Maghrabian region. Tectonophysics 248: 247-261.

Calvert, A., Sandvol, E., Seber, D., Barazangi, M., Roecker, S., Mourabit, T., Vidal, F., Alguacil, G. \& Jabour, N., 2000. Geodynamic evolution of the lithosphere and upper mantle beneath the Alboran region of the western Mediterranean: constraints from travel time tomography. Journal of Geophical Research B, 105: 10.871-10.898.

Calvo, M., Vegas, R. \& Osete, M.L., 1997. Palaeomagnetic results from Upper Miocene and Pliocene rocks from the Internal Zone of the eastern Betic Cordilleras (southern Spain). Tectonophysics 277: 271-283.

Campillo, A.C., Maldonado, A. \& Mauffret, A., 1992. Stratigraphic and tectonic evolution of the western Alboran Sea: Late Miocene to Recent. Geo-Marine Letters 12: 165-172.

Campos, J., Maldonado, A. \& Campillo, A.C., 1992. Post-Messinian evolutional patterns of the central Alboran Sea. Geo-Marine Letters 12: 173-178.

Carminati, E., Wortel, M.J.R., Spakman, W. \& Sabadin, R., 1998. The role of slab detachment processes in the opening of the western-central Mediterranean basins: some geological and geophysical evidence. Earth and Planetary Science Letters 160: 651-665.

Cater, J.M.L., 1987. Sedimentary evidence of the Neogene evolution of SE Spain. Journal of the Geological Society (London) 144: 915-932.

Chalouan, A., Ouazani-Touhami, A., Mouhir, L., Saji, R. \& Benmakhlouf, M., 1995. Les failles normales à faible pendage du Rif interne (Maroc) et leur effet sur l'amincissement crustal du domaine d'Alboran. Geogaceta 17: 107-109.

Chalouan, A., Saji, R., Michard, A. \& Bally, A.W., 1997. Neogene tectonic evolution of the southwestern Alboran Basin as infered from seismic data off Morocco. American Association of Petroleum Geologists Bulletin 81: 1161-1184.

Chalouan, A., Michard, A., Feinberg, H., Montigny, R., Saddiqi, O., 2001. The Rif mountain building (Morocco): a new tectonic scenario. Bulletin de la Société Géologique de France 172 : 603-616.

Chalouan, A., El Mrihi, A. El Kadiri, K., Bahmad, A., Salhi, F., Hlila, R., 2006 a. Mauretanian flysch nappe in the northwestern Rif Cordillera (Morocco): deformation chronology and evidence for a complex nappe emplacement. Geological Society Special Publication (London) 262: 161-175.
Chalouan, A., Galindo-Zaldivar, J., Akil, M., Marín, C., Chabli, A., Ruano, P., Bargach, K., Sanz de Galdeano, C., Benmakhlouf, M., Ahmamou, M. \& Gourari, L., 2006b. Tectonic wedge escape in the southwestern front of the Rif Cordillera (Morocco). Geological Society Special Publication (London) 262: 101-118.

Chotin, P. \& Aït Brahim, L., 1988. Transpression et magmatisme au NéogèneQuaternaire dans le Maroc oriental. Comptes Rendus de l'Académie des Sciences (Paris) 2, 306: 1479-1485.

Comas, M.C., Garcia-Dueñas, V. \& Jurado, M.J., 1992. Neogene tectonic evolution of the Alboran Sea from MSC data. Geo-Marine Letters 12: 157-164.

Comas, M.C, Platt, J.P., Soto, J.I. \& Watts, A.B., 1999. The origin and tectonic history of the Alboran Basin: insights from Leg 161 results. In: Zahn, R., Comas, M.C. \& Klaus, A. (eds): Proceedings of the Ocean Drilling Program, Scientific Results 161: 555-580.

Cornée, J.-J., Roger, S., Münch, P., Saint Martin, J.-P., Féraud, G., Conesa, G. \& Pestrea-Saint Martin, S., 2002. Messinian events: new constraints from sedimentological investigations and new 40Ar/39Ar ages in the MelillaNador Basin (Morocco). Sedimentary Geology 151: 127-147.

Crespo-Blanc, A., Orozco, M. \& García-Dueñas, V., 1994. Extension versus compression during the Miocene tectonic evolution of the Betic chain. Late folding of normal fault systems. Tectonics 13: 78-88.

Croese, I., 1982. Neogene formations and dating of deformation in the Prebetic zone, southeast of Jumilla (Prov. of Murcia, Spain). Estudios Geológicos 38: 415-423.

Cunningham, K.J. \& Collins, L.S., 2002. Controls on facies and sequence stratigraphy of an upper Miocene carbonate ramp and platform, Melilla basin, NE Morocco. Sedimentary Geology 146: 285-304.

Cunningham, K.J., Benson, R.H., Rakic-El Bied, K., McKenna, L.W., 1997. Eustatic implications of late Miocene depositional sequences in the Melilla Basin, northeastern Morocco. Sedimentary Geology 107: 147-165.

Dabrio, C., Martín, J.M., Megias, A.G., 1982. Signification sédimentaire des évaporites de la dépression de Grenade (Espagne). Bulletin de la Société Géologique de France 7, 24 : 705-710.

De Jong, K., 1991. Tectonometamorphic Studies and Radiometric Dating in the Betic Cordilleras (SE Spain) - With Implications for the Dynamics of Extension and Compression in the Western Mediterranean Area. Ph.D. Thesis, Free Univ. (Amsterdam): $204 \mathrm{pp}$.

De Lazouzière, F.D. \& Ott d'Estevou, P., 1990. Les bassins d'Hinojar et de Mazarron. Documents et Travaux de l'IGAL 12-13: 207-220.

De Lazouriere, F.D., Montenat, C., Ott d'Estevou, P. \& Griveaud, P., 1987. Evolution simultanée de bassins néogènes en compression et en extension dans un couloir de décrochement: Hinojar et Mazarrón (Sud-Est de l'Espagne). Bulletin des Centres de Recherches Exploration-Production Elf-Aquitaine 11: 23-38.

De Larouzière, F.D., Bolze, J., Bordet, P., Hernandez, J., Montenat, C. \& Ott d'Estevou, P., 1988. The Betic segment of the lithospheric Trans-Alboran shear zone during the Late Miocene. Tectonophysics 152: 41-52.

De Luca, P., 1985. Passage du cycle tortonien au cycle messinien dans le bassin de Nador, implications paléogéographiques et structurales. Bulletin de l'Institut Scientifique (Rabat) 9: 122.

De Ruig, M.J., 1990. Fold trends and stress deviation in the Alicante fold belt, southeastern Spain. Tectonophysics 184: 393-403. 
De Ruig, M.J., 1992. Tectono-sedimentary Evolution of the Prebetic Fold Belt of Alicante (SE Spain). Ph.D. Thesis, Free Univ. (Amsterdam): 207 pp.

De Smet, M.E.M., 1984. Investigations of the Crevillente Fault Zone and its Role in the Tectogenesis of the Betic Cordilleras, Southern Spain. Ph.D. Thesis, Free Univ. (Amsterdam): $174 \mathrm{pp}$.

Dewey, J.F., Helman, M.L., Turco, E., Hutton, D.H.W. \& Knott, S.D., 1989. Kinematics of the western Mediterranean. Geological Society Special Publication (London) 45: 265-283.

Di Battistini, G., Toscani, L., Iaccarino, S. \& Villa, I.M., 1987. K/Ar ages and the geological setting of calc-alkaline volcanic rocks from Sierra de Gata, SE Spain. Neues Jahrbuch für Mineralogie: Monatshefte 8: 369-383.

Didon, J., Durand Delga, M. \& Kornprobst, J., 1973. Homologies géologiques entre les deux rives du détroit de Gibraltar. Bulletin de la Société Géologique de France 7, 15: 77-105.

Dinarès-Turell, J., Ortí, F., Play`a, E. \& Rosell, L., 1999. Palaeomagnetic chronology of the evaporitic sedimentation in the Neogene Fortuna Basin (SE Spain): early restriction preceding the 'Messinian Salinity Crisis'. Palaeogeogaphy, Palaeoclimatology, Palaeoecology 154: 161-178.

Doblas, M. \& Oyarzun, R., 1989. Neogene extensional collapse in the western Mediterranean (Betic-Rif Alpine orogenic belt): implications for the genesis of the Gibraltar Arc and magmatic activity. Geology 17: 430-433.

Docherty, C. \& Banda, E., 1995. Evidence for the eastward migration of the Alboran sea based on regional subsidence analysis: a case for basin formation by delamination of the subcrustal lithosphere ? Tectonics 14: 804-818.

Durand-Delga, M. \& Olivier, P., 1988. Evolution of the Alboran block margin from early Mesozoic to early Miocene time. Lecture Notes in Earth Science 15: $465-480$.

Durand-Delga, M., Feinberg, H., Magné, J. Olivier, P. \& Anglada, R., 1993. Les formations oligo-miocène discordantes sur les Malaguides et les Alpujarrides et leurs implications dans l'évolution géodynamique des Cordillères bétiques (Espagne) et de la Méditerranée d'Alboran. Comptes Rendus de l'Académie des Sciences (Paris) 2, 317: 679-687.

Egeler, C.G. \& Simon, O.J., 1969. Orogenic evolution of the Betic Zone (Betic Cordilleras, Spain), with emphasis on the nappe structure. Geologie en Mijnbouw 48: 296-305.

El Bakkali, S., Gourgaud, A., Bourdier, J.-L., Bellon, H. \& Gundoghu, N., 1998. Post-collision Neogene volcanism of the Eastern Rif (Morocco): magmatic evolution through time. Lithos 45: 523-543.

El Kadiri, K., Chalouan, A., El Mrihi, A., Hlila, R., López-Garrido, A.C., Sanz de Galdeano, C. \& Serrano, F., 2000. Descubrimiento del Burdigaliense (formación Viñuela) en la cobertera Gomáride de Ceuta (Rif septentrional). Geogaceta 28: 43-46.

El Kadiri, K., Chalouan, A., El Mrihi, A. Hlila, R., López-Garrido, A.C., Sanz de Galdeano, C., Serrano, F. \& Kerzazi, K., 2001. Les formations sédimentaires olistolithiques de l'Oligocène supérieur-Miocène inférieur dans l'unité ghomaride des Béni Hozmar (secteur de Talembote, Rif septentrional, Maroc). Eclogae Geologicae Helvetiae 94: 313-320.

El Kharim, Y., 1991. Sédimentologie et Palynologie du Néogène du Bassin de Boudinar: Implications Paléogéographiques et Paléoclimatiques (Rif Nordoriental, Maroc). Documents des Laboratoires de Géologie de Lyon 117: 153 pp.

Estévez, A., Rodríguez-Fernández, J., Sanz de Galdeano, C. \& Vera, J.A. 1982. Evidencia de una compresiva de edad Tortonense en el sector central de las Cordilleras Béticas. Estudios Geol. 38: 55-60.
Estévez, A., González-Donoso, J.M., Linares, D., Martin-Algarra, A., Sanz de Galdeano, C. \& Serrano, F., 1984. El cabalgamiento finiserravallense del norte de Sierra Arana (Cordillera Bética). Observaciones sobre la caracterización del bioestratigráfica del Serravallense. Mediterránea: Serie de Estudios Geológicos 3: 151-173.

Fallot, P., 1948. Les Cordillères Bétiques. Estudios Geológicos 8: 83-172.

Faulkner, D.R., Lewis, A.C. \& Rutter, E.H., 2003. On the internal structure and mechanics of large strike-slip fault zones: field observations of the Carboneras fault in southeast Spain. Tectonophysics 367: 235- 251.

Feinberg, H., Maate, A., Bouhdadi, S., Durand-Delga, M., Maate, M., Magné, J. \& Olivier, P., 1990. Signification des dépôts de l'Oligocène supérieurMiocène inférieur du Rif interne (Maroc), dans l'évolution géodynamique de l'Arc de Gibraltar. Comptes Rendus de l'Académie des Sciences (Paris) 2, 310 : 1487-1495.

Fernández, J. \& Rodriguez-Fernández, J., 1991. Facies evolution of nearshore marine clastic deposits during the Tortonian transgression - Granada Basin, Betic Cordilleras, Spain. Sedimentary Geology 71: 5-21.

Fernández, J., Soria, J. \& Viseras, C., 1996. Stratigraphic architecture of the Neogene basins in the central sector of the Betic Cordillera (Spain): tectonic control and base-level changes. In: Friend, P.F. \& Dabrio, C.J. (eds): Tertiary Basins of Spain: The Stratigraphic Record of Crustal Kinematics. Cambridge Univ. Press (Cambridge): 353-365.

Fernández, M., Berástegui, X., Puig, D., García-Castellanos, D., Jurado, M.J., Torné, M. \& Banks, C., 1998. Geophysical and geological constraints on the evolution of the Guadalquivir foreland basin, Spain. Geological Society Special Publication (London) 134: 29-48.

Fernández-Soler, J.M., 2001. Volcanics of the Almería Province. In: Mather, A.E., Martín, J.M., Harvey, A.M. \& Braga, J.C. (eds): A Field Guide to the Neogene Sedimentary Basins of the Almeriá Province, SE Spain. Blackwell Science (0xford): 58-88.

Flinch, J.F., 1996. Accretion and extensional collapse of the external Western Rif (Northern Morocco). Mémoires du Muséum National d'Histoire Naturelle (Paris) 170: 61-85.

Flinch, J.F., Bally, A.W. \& Wu, S., 1996. Emplacement of a passive-margin evaporitic allochthon in the Betic Cordillera of Spain. Geology 24: 67-70.

Fortuin, A.R. \& Krijgsman, W., 2003. The Messinian of the Nijar Basin (SE Spain): sedimentation, depositional environments and paleogeographic evolution. Sedimentary Geology 160: 213-242.

Fortuin, A.R., Kelling, J.M.D. \& Roep, T.B., 1995. The enigmatic MessinianPliocene section of Cuevas del Almanzora (Vera Basin, SE Spain) revisited erosional features and strontium isotope ages. Sedimentary Geology 97: 177-201.

Frizon de Lamotte, D., 1987. La structure du Rif externe (Maroc): mise au point sur le rôle des decrochements, des chevauchements et des glissements gravitaires. Journal of African Earth Sciences 6: 755-766.

Frizon de Lamotte, D., Guézou, J.C. \& Albertini, M.-A., 1989. Deformation related to Miocene westward translation in the core of the Betic zone: implications on the tectonic interpretation of the Betic orogen (Spain). Geodinamica Acta 3: 267-281.

Frizon de Lamotte, D., Andrieux, J. \& Guézou, J.C., 1991. Cinématique des chevauchements néogènes dans l'Arc bético-rifain: discussion sur les modèles géodynamiques. Bulletin de la Société Géologique de France 162: 611-626. 
Frizon de Lamotte, D., Saint Bezar, B., Bracène, R. \& Mercier, E., 2000. The two main steps of the Atlas building and geodynamics of the western Mediterranean. Tectonics 19: 740-761.

Galindo-Zaldivar, J., González-Lodeiro, F. \& Jabaloy, A., 1989. Progressive extensional shear structures in a detachment contact in the Western Sierra Nevada (Betic Cordilleras, Spain). Geodinamica Acta 3: 295-304.

Galindo-Zaldivar, J., Gonzalez-Lodeiro, F. \& Jabaloy, A., 1993. Stress and paleostress in the Betic-Rif Cordilleras (Miocene to the present). Tectonophysics 266: 405-424.

Galindo-Zaldivar, J., Jabaloy, A., Serrano, I., Morales, J., Conzález-Lodeiro, F. \& Torcal, F., 1999. Recent and present-day stresses in the Granada Basin (Betic Cordilleras): example of a late Miocene present-day extensional basin in a convergent plate boundary. Tectonics 18: 686-702.

Garcés, M., Krijgsman, W. \& Agusti, J., 1998. Chronology of the late Turolian deposits of the Fortuna basin (SE Spain): implications for the Messinian evolution of the eastern Betics. Earth and Planetary Science Letters 163: 69-81.

Garcés, M., Krijgsman, W. \& Agusti, J., 2001. Chronostratigraphic framework and evolution of the Fortuna basin (Eastern Betics) since the Late Miocene. Basin Research 13: 199-216.

García Aguilar, J.M. \& Martín, J.M., 2000. Late Neogene to Recent continental history and evolution of the Guadix-Baza basin (SE Spain). Revista de la Sociedad Geológica de España 13: 65-77.

García-Dueñas, V., Balanyá, J.C. \& Martínez-Martínez, J.M., 1992. Miocene extensional detachments in the outcropping basement of the northern Alboran basin and their tectonic implications. Geo-Marine Letters 12: 88-95.

García García, F., Viseras, C. \& Fernández, J., 1999. Organización secuencial de abanicos deltaicos controlados por la tectónica (Tortoniense superior, Cuenca de Granada, Cordillera Bética). Revista de la Sociedad Geológica de España 12: 199-208.

García-Hernández, M., López-Garrido, A.C., Rivas, P., Sanz de Galdeano, C. \& Vera, J.A., 1980. Mesozoic palaeogeographic evolution of the External Zones of the Betic Cordillera. Geologie en Mijnbouw 59: 155-168.

Gauyau, F., Bayer, R., Bousquet, J.-C., Lachaud, J.-C., Lesquer, A. \& Montenat, C., 1977. Le prolongement de l'accident d'Alhama de Murcia entre Murcia et Alicante (Espagne méridionale): résultats d'une étude géophysique. Bulletin de la Société Géologique de France 7 19: 623-629.

Geel, T., 1995. Oligocene to early Miocene tectonosedimentary history of the Alicante region (SE Spain): implications for Western Mediterranean evolution. Basin Research 7: 313-336.

Geel, T. \& Roep, T.B., 1999. Oligocene to Middle Miocene basin development in the Vélez Rubio Corridor - Espuña (Internal-External Zone Boundary; eastern Betic Cordilleras, SE Spain). Geologie en Mijnbouw 77: 39-61.

Geel, T., Roep, T. B., Ten Kate, W. \& Smit, J., 1992. Early-Middle Miocene stratigraphic turning points in the Alicante region (SE Spain): reflections of Western Mediterranean plate-tectonic reorganizations. Sedimentary Geology 75: 223-239.

Gelati, R., Moratti, G. \& Papani, G., 2000. The Late Cenozoic sedimentary succession of the Taza-Guercif Basin, South Rifian Corridor, Morocco. Marine and Petroleum Geology 17: 373-390.

Gil, A.J., Rodríguez-Caderot, G., Lacy, M.C., Ruiz, A.M., Sanz de Galdeano, C. \& Alfaro, P., 2002. Establishment of a non-permanent GPS network to monitor the Recent NE-SW deformation in the Granada Basin (Betic Cordillera, southern Spain). Studia Geophysica et Geodaetica 46: 395-410.
Gläser, I. \& Betzler, C., 2002. Facies partitioning and sequence stratigraphy of cool-water, mixed carbonate-siliciclastic sediments (Upper Miocene Guadalquivir Domain, southern Spain. International Journal of Earth Sciences 91: 1041-1053.

Gomez, F., Barazangi, M. \& Demnati, A., 2000. Structure and evolution of the Neogene Guercif basin at the junction of the Middle Atlas mountains and the Rif thrust belt. American Association of Petroleum Geologists Bulletin 84: 1340-1364.

González-Lodeiro, F., Aldaya, F., Galindo-Zaldívar, J. \& Jabaloy, A., 1996. Superposition of extensional detachments during the Neogene in the internal zones of the Betic cordilleras. Geologische Rundschau 85: 350-362.

Gradstein, F.M., Ogg, J.G. \& Smith, A.G. (eds), 2004. A Geologic Time Scale. Cambridge Univ. Press (Cambridge): 589 pp.

Guerra-Mechán, A. \& Serrano, F., 1993. Tectonosedimentary setting and chronostratigraphy of the Neogene reefs in the Almanzora Corridor (Betic Cordillera, Spain). Geobios 26: 57-67.

Guerrera, F., Martin-Algarra, A. \& Perrone, V., 1993. Late Oligocene-Miocene syn-/late-orogenic successions in Western and Central Mediterranean chains from the Betic Cordillera to the Southern Apennines. Terra Nova 5: 525-544.

Guillemin, M. \& Houzay, J.-P., 1982. Le Néogène post-nappes et le Quaternaire du Rif nord-oriental (Maroc): stratigraphie et tectonique des bassins de Melilla, du Kert, de Boudinar et du piedmont des Kebdana. Notes et Mémoires du Service Géologique du Maroc 314: 7-238.

Gutscher, M.-A., Malod, J., Rehault, J.-P., Contrucci, I., Klingelhoefer, F., Mendes-Victor, L. \& Spakman, W., 2002. Evidence for active subduction beneath Gibraltar. Geology 30: 1071-1074.

Haughton, P., 2001. Contained turbidites used to track sea bed deformation and basin migration, Sorbas Basin, southeast Spain. Basin Research 13: 117-139.

Henares, J., López Casado, C., Sanz de Galdeano, C., Delgado, J. \& Peláez, J.A., 2003. Stress fields in the Iberian-Maghrebi region. Journal of Seismology 7: 65-78.

Hermes, J.J., 1978. The stratigraphy of the Subbetic and southern Prebetic of the Velez Rubio- Caravaca area and its bearing on transcurrent faulting in the Betic Cordilleras of southern Spain. Proceedings of the Koninklijke Nederlandse Akademie van Wetenschappen B 81: 1-54.

Hermes, J.J., 1984. New data from the Vélez Rubio Corridor: support for the transcurrent nature of this linear structure. Proceedings of the Koninklijke Nederlandse Akadademie van Wetenschappen B 87: 319-333.

Hernandez, J. \& Bellon, H., 1985. Chronologie K-Ar du volcanisme miocène du Rif oriental: implications tectoniques et magmatologiques. Revue de Géologie Dynamique et de Géographie Physique 26: 85-94.

Hernandez, J., De Larouzière, F.D., Bolze, J. \& Bordet, P., 1987. Le magmatisme néogène bético-rifain et le couloir de décrochement trans-Alboran. Bulletin de la Société Géologique de France 8, 3: 257-267.

Hlila, $R$. \& Sanz de Galdeano, C., 1995. Structure, cinématique et chronologie de déformations dans la dorsale du Haouz (Rif, Maroc). Geogaceta 17: 95-97.

Hoedemaeker, P.J., 1973. Olistostromes and other delapsional deposits, and their occurrences in the region of Moratalla (Prov. of Murcia, Spain). Scripta Geologica 19: 1-207.

Huibregtse, P., Van Alebeek, H., Zaal, M. \& Biermann, C., 1998. Palaeostress analysis of the northern Nijar and southern Vera basins: constraints for the Neogene displacement history of major strike-slip faults in the Betic Cordilleras, SE Spain. Tectonophysics 300: 79-101. 
IGME, 1974. Mapa geológico de España, escala $1: 50.000$. Explicación de la hoja 26-36, Cieza. IGME (Madrid).

Jabaloy, A., Galindo-Zaldivar, J. \& González-Lodeiro, F., 1992. The Mecina Extensional System: its relation with the post-Aquitanian piggy-back basins and the paleostress evolution (Betic Cordilleras, Spain). Geo-Marine Letters 12: $96-103$.

Jabaloy, A., Galindo-Zaldivár, J. \& González-Lodeiro, F., 1993. The AlpujárrideNevado-Filábride extensional shear zone, Betic Cordillera, SE Spain. Journal of Structural Geology 15: 555-569.

Jacobshagen, V., 1992. Major fracture zones of Morocco: the South Atlas and the Transalboran fault systems. Geologische Rundschau 81: 185-197.

Jonk, R. \& Biermann, C., 2002. Deformation in Neogene sediments of the Sorbas and Vera basins (SE Spain): constraints on simple-shear deformation and rigid body rotation along major strike-slip faults. J. Struct. Geol. 24: 963-977.

Jurado, M.J. \& Comas, M.C., 1992. Well log interpretation and seismic character of the Cenozoic sequence in the northern Alboran Sea. Geo-Marine Letters 12: 129-136.

Keller, J.V.A., Hall, S.H., Dart, C.J. \& McClay, K.R., 1995. The geometry and evolution of a transpressional strike-slip system: the Carboneras fault, SE Spain. Journal of the Geological Society (London) 152: 339-351.

Kenter, J.A.M., Reymer, J.J.G., Van der Straaten, H.C. \& Peper, T., 1990. Facies patterns and subsidence history of the Jumilla-Cieza region (southeastern Spain). Sedimentary Geology 67: 263-280.

Kerchaoui, S. \& Morel, J.-L., 1984. Tectonique compressive intra-messinienne dans le Rif oriental (Maroc). Comptes Rendus de l'Académie des Sciences (Paris) 2, 299: 1279-1282.

Kirker, A.I. \& Platt, J.P., 1998. Unidirectional slip vectors in the western Betic Cordillera: implications for the formation of the Gibraltar Arc. Journal of the Geological Society (London) 155: 193-208.

Krijgsman, W., Hilgen, F.J., Raffi, I., Sierro, F.J. \& Wilson, D.S., 1999a. Chronology, causes and progression of the Messinian salinity crisis. Nature 440: 652-655.

Krijgsman, W., Langereis, C.G., Zachariasse, W.J., Boccaletti, M., Moratti, G., Gelati, R., Iaccarino, S., Papani, G. \& Villa, G., 1999b. Late Neogene evolution of the Taza-Guercif Basin (Rifian Corridor, Morocco) and implications for the Messinian salinity crisis. Marine Geology 153: 147-160.

Krijgsman, W., Garcés, M., Agusti, J., Raffi, C. Taberner, C. \& Zachariasse, J.W., 2000. The 'Tortonian salinity crisis' of the eastern Betics (Spain). Earth and Planetary Science Letters 181: 497-511.

Krijgsman, W., Fortuin, A.R., Hilgen, F.J. \& Sierro, F.J., 2001. Astrochronology for the Messinian Sorbas basin (SE Spain) and orbital (precessional) forcing for evaporite cyclicity. Sedimentary Geology 140: 43-60.

Krautworst, U.M.R. \& Brachert, T.C., 2003. Sedimentary facies during early stages of flooding in an extensional basin: the Brèche Rouge de Carboneras (Late Miocene, Almería/SE Spain). International Journal of Earth Sciences 92: 610-623.

Leblanc, D., 1980. L'accident du Nekor et la structure du Rif oriental (Maroc). Revue de Géologie Dynamique et de Géographie Physique 22: 267-277.

Leblanc, D., 1990. Tectonic adaptation of the External Zones around the curved core of an orogen: the Gibraltar Arc. Journal of Structural Geology 12: $1013-$ 1018
Leblanc, D. \& Marçais, J., 1979. Mise en évidence d'une tectonique diapirique tardive dans le Rif oriental (Maroc), conséquences. Comptes Rendus de l'Académie des Sciences (Paris) D, 298: 571-574.

Litto, W., Bachir Jaaida, E., Medina, F. \& Dakki, M., 2001. Etude sismostructurale de la marge nord du bassin du Gharb (avant-pays rifain, Maroc): mise en évidence d'une distension d'âge miocène tardif. Eclogae Geologicae Helvetiae 94: 63-74.

Lonergan, L., 1993. Timing and kinematics of deformation in the Malaguide Complex, Internal Zone of the Betic Cordillera, southeast Spain. Tectonics 12: $460-476$

Lonergan, L. \& Mange-Rajetzky, M.A., 1994. Evidence for Internal Zone unroofing from foreland basin sediments, Betic Cordillera, SE Spain. Journal of the Geological Society (London) 151: 515-529.

Lonergan, L. \& White, N., 1997. Origin of the Betic-Rif mountain belt. Tectonics 16: 504-522.

Lonergan, L., Platt, J.P. \& Callagher, L., 1994. The Internal-External Zone Boundary in the eastern Betic Cordillera, SE Spain. Journal of Structural Geology 16: 175-188.

Lopes, F.C. \& Proença Cunha, P., 2000. Estratigrafia sísmica do Cenozóico na plataforma continental algarvia: interpretaçao do controle tectónico da sedimentaçao. Ciências da Terra (UNL) 14: 257-276.

López-Garrido, A.C. \& Sanz de Galdeano, C., 1999. Neogene sedimentation and tectonic-eustatic control of the Malaga Basin, South Spain. Journal of Petroleum Geology 22: 81-96.

Lukowski, P. \& Poisson, A., 1990. Le bassin de Fortuna. Documents et Travaux de l'IGAL 12-13: 303-311.

Maate, A., Martín-Pérez, J.A., Martín-Algarra, A., Serrano, F., Aguado, R., Martín-Martín, M. \& El Hajjaji, K., 1995. Le Burdigalien inférieur de Boujarrah (Rif septentrional, Maroc) et la signification paléotectonique des séries miocènes transgressives sur les zones internes bético-rifaines. Comptes Rendus de l'Académie des Sciences (Paris) 2a, 320: 15-22.

Maestro, A., Somoza, L., Medialdea, T., Talbot, C.J., Lowrie, A., Vázquez, T. \& Díaz-del-Río, V., 2003. Large-scale slope failure involving Triassic and Middle Miocene salt and shale in the Gulf of Cádiz (Atlantic Iberian Margin). Terra Nova 15: 380-391.

Maldonado, A. \& Nelson, C.H., 1999. Interaction of tectonic and depositional processes that control the evolution of the Iberian Gulf of Cadiz margin. Marine Geology 155: 217-242.

Maldonado, A, Somoza, L. \& Pallarés, L., 1999. The Betic orogen and the Iberian-African boundary in the Gulf of Cadiz: geological evolution (central North Atlantic). Marine Geology 155: 9-43.

Martín, J.M. \& Braga, 1996. Tectonic signals in the Messinian stratigraphy of the Sorbas basin (Almería, SE Spain). In: Friend, P.F. \& Dabrio, C.J. (eds): Tertiary Basin of Spain: The Stratigraphic Record of Crustal Kinematics. Cambridge Univ. Press (Cambridge): 387-391.

Martín-Algarra, A., Sanz de Galdeano, C. \& Estevez, A., 1988. L'évolution sédimentaire miocène de la région au nord de la Sierra Arana (Cordillères bétiques) et sa relation avec la mise en place du bloc d'Alboran. Bulletin de la Société Géologique de. France 8, 4: 119-127.

Martín Suarez, E., Freudenthal, M. \& Agusti, J., 1993. Micromammals from the Middle Miocene of the Granada Basin (Spain). Geobios 26: 377-387. 
Martinez-Díaz, J.J., 2002. Stress field variation related to fault interaction in a reverse oblique-slip fault: the Alhama de Murcia fault, Betic Cordillera. Tectonophysics 356: 291-305.

Martínez-Martínez, J.M.\& Azañón, J.M., 1997. Mode of extensional tectonics in the southeastern Betics (SE Spain): implications for the tectonic evolution of the peri-Alboran orogenic system. Tectonics 19: 205-225.

Martinez-Martínez, J.M. \& Azañón, J.M., 2002. Orthogonal extension in the hinterland of the Gibraltar Arc (Betics, SE Spain). Journal of the Virtual Explorer 8: 3-22.

Mather, A.E., Braga, J.C., Martín, J.M. \& Harvey, A.M., 2001. Introduction to the Neogene geology of the Sorbas Basin. In: Mather, A.E., Martin, J.M., Harvey, A.M. \& Braga, J.C. (eds): A Field Guide to the Neogene Sedimentary Basins of the Almería Province, SE Spain. Blackwell Science (0xford): 9-28.

Mauffret, A., Frizon de Lamotte, D., Lallemant, S. Gorini, C. \& Maillard, A. 2004. E-W opening of the Algerian Basin (Western Mediterranean). Terra Nova 16: 257-264.

Medialdea, T., Vegas, R., Somoza, Vázquez, J.T., Maldonado, A. Díaz-del-Río, V., Maestro, A., Córdoba, D. \& Fernández-Puga, M.C., 2004. Structure and evolution of the 'Olistostrome' complex of the Gibraltar Arc in the Gulf of Cadíz (eastern Central Atlantic): evidence from two long seismic crosssections. Marine Geology 209: 173-198.

Meghraoui, M., Morel, J.-L., Andrieux, J. \& Dahmani, M., 1996. Tectonique plio-quaternaire de la chaine tello-rifaine et de la mer d'Alboran. Une zone complexe de convergence continent-continent. Bulletin de la Société Géologique de France 167: 141-157.

Meijninger, B.M.L., 2006. Late-orogenic extension and strike-slip deformation in the Neogene of southeastern Spain. Geologica Ultrajectina 269: $179 \mathrm{pp}$.

Michard, A., 1976. Eléments de Géologie Marocaine. Notes et Mémoires du Service Géologique du Maroc 252: 408 pp.

Michard, A., Chalouan, A., Benyaïch, A., Samaka, F., Dakki, M. \& Bally, A.W., 1996. Commentaire sur la note: 'Les bassins du Rif central (Maroc): marqueurs de chevauchements hors-séquence d'âge miocène terminal au coeur de la chaîne'. Bulletin de la Société Géologique de France 167: 657662.

Michard, A., Chalouan, A., Feinberg, H., Goffé, B. \& Montigny, R., 2002. How does the Alpine belt end between Spain and Morocco? Bulletin de la Société Géologique de France 173: 3-15.

Montenat, C., Ott d'Estevou, P. \& La Chapelle, G., 1990a. Le bassin de NijarCarboneras et le couloir du Bas-Andarax. Documents et Travaux de l'IGAL 1213: $129-164$.

Montenat, C., Ott d'Estevou, P. \& Delort, T., 1990b. Le bassin de Lorca. Documents et Travaux de l'IGAL 12-13:261-280.

Montenat, C., Ott d'Estevou, P. \& Coppier, G., 1990c. Les bassins néogène entre Alicante et Cartagena. Documents et Travaux de l'IGAL 12-13: 313-368.

Montenat, C., Ott d'Estevou, P. \& Pierson d'Autrey, L., 1996. Miocene basins of the eastern Prebetic Zone: some tectonosedimentary aspects. In: Friend, P.F. \& Dabrio, C.J. (eds): Tertiary Basins of Spain: The Stratigraphic Record of Crustal Kinematics. Cambridge Univ. Press (Cambridge): 346-352.

Mora-Gluckstadt, M., 1993. Tectonic and Sedimentary Analysis of the HuercalOvera Region, Southeast Spain, Betic Cordillera. Ph.D. Thesis, Univ. Oxford (Oxford): $232 \mathrm{pp}$.
Morales, J., Serrano, I., Vidal, F. \& Torcal, F., 1997. The depth of the earthquake activity in the Central Betics (Southern Spain). Geophysical Research Letters 24: 3289-3292.

Morales, J., Serrano, I., Jabaloy, A., Galindo-Zaldivar, J., Zhao, D., Torcal, F., Vidal, F. \& González-Lodeiro, F., 1999. Active continental subduction beneath the Betic Cordillera and Alborán Sea. Geology 27: 735-738.

Morel, J.L., 1984. Tectonique compressive, au Messinien, dans le Rif (Maroc). Comptes Rendus de l'Académie des Sciences (Paris) 2, 298: 137-140.

Morel, J.-L., 1989. Etats de contrainte et cinématique de la chaine rifaine (Maroc) du Tortonien à l'actuel. Geodinamica Acta 3: 283-294.

Morley, C.K., 1988. The tectonic evolution of the Zoumi Sandstone, western Moroccan Rif. Journal of the Geological Society (London) 145: 55-63.

Morley, C.K., 1992. Notes on Neogene basin history of the Western Alboran Sea and its implications for the tectonic evolution of the Rif-Betic orogenic belt. Journal of African Earth Sciences 14: 57-65.

Morley, C.K., 1993. Discussion of origins of hinterland basins to the Rif-Betic Cordillera and Carpathians. Tectonophysics 226: 359-376.

Münch, P., Roger, S., Cornée, J.-J., Saint Martin, J.-P., Féraud, G. \& Ben Moussa, A., 2001. Restriction des communications entre l'Atlantique et la Méditerranée au Messinien: apport de la téphrochronologie dans la plateform carbonatée et le bassin de Melilla-Nador (Rif nord-oriental, Maroc). Comptes Rendus de l'Académie des Sciences (Paris) 2a, 332: 569-576.

Olivier, P., 1982. L'accident de Jebha-Chrafate (Rif, Maroc). Revue de Géologie Dynamique et de Géographie Physique 23: 97-106.

Osete, M.L., Freeman, R. \& Vegas, R., 1989, Paleomagnetic evidence for block rotations and distributed deformation of the Iberian-African plate boundary. In: Kissel, C. \& Laj, C. (eds): Paleomagnetic Rotations and Continental Deformation. Kluwer Acad. Publ. (Dordrecht): 381-391.

Ott d'Estevou, P., 1980. Evolution dynamique du bassin neogène de Sorbas (Cordillères Bétiques Orientales, Espagne). Documents et Travaux de l'IGAL 1: 264 pp.

Ott d'Estevou, P. \& Montenat, C., 1985. Évolution structurale de la zone bétique orientale (Espagne) du Tortonien à l'Holocène. Comptes Rendus de l'Académie des Sciences (Paris) 2, 300: 363-368.

Ott d'Estevou, P. \& Montenat, C., 1990. Le bassin de Sorbas-Tabernas. Documents et Travaux de l'IGAL 12-13: 101-128.

Ott d'Estevou, P., Montenat, C., Ladure, F. \& Pierson d'Autrey, L., 1988. Évolution tectonosédimentaire du domain prébétique oriental (Espagne) au Miocene. Comptes Rendus de l'Académie des Sciences (Paris) 2, 307: 789-796.

Ott d'Estevou, P., Montenat, C. \& Alvado, J.-C., 1990. Le bassin de VeraGarrucha. Documents et Travaux de l'IGAL 12-13: 165-187.

Ouazani-Touhami, A. \& Chalouan, A., 1995. La distension de l'0ligocène supérieur à Burdigalien dans les nappes Ghomarides (Rif interne septentrional, Maroc). Geogaceta 17: 113-116.

Pais, J., Legoinha, P., Elderfield, H., Sousa, L. \& Estevens, M., 2000. The Neogene of Algarve (Portugal). Ciências da Terra (UNL) 14: 277-288.

Pedrera, A., Marín-Lechado, C., Galindo-Zaldivar, J., Rodríguez-Fernández, L.R. \& Ruiz-Constân, A., 2006. Fault and fold interaction during the deveopment of the Neogene-Quaternary Almería-Nijar basin (SE Betic Cordilleras). Geological Society Special Publication (London) 262: 217-230.

Piqué, A., 2001. Geology of Northwest Africa. Borntraeger (Berlin - Stuttgart): $310 \mathrm{pp}$. 
Platt, J.P., 1998. Comment on 'Alternating contractional and extensional events in the Alpujarride napes of the Alboran Domain (Betics, Gibraltar Arc)' by Juan C. Balanyá et al. Tectonics 17: 973-976.

Platt, J.P. \& Whitehouse, M.J., 1999. Early Miocene high-temperature metamorphism and rapid exhumation in the Betic Cordillera (Spain): evidence from U-Pb zircon ages. Earth and Planetary Science Letters 171: 591-605.

Platt, J.P. \& Vissers, R.L.M., 1989. Extensional collapse of thickened continental lithosphere: a working hypothesis for the Alboran Sea and Gibraltar arc. Geology 17: 540-543.

Platt, J.P., Allerton, S., Kirker, A. \& Platzman, E., 1995. Origin of the western Subbetic arc (South Spain): palaeomagnetic and structural evidence. Journal of Structural Geology 17: 765-775.

Platt, J.P., Soto, J.-I., Whitehouse, M.J. Hurford, A.J. \& Kelley, S.P., 1998. Thermal evolution, rate of exhumation, and tectonic significance of metamorphic rocks from the floor of the Alboran extensional basin, western Mediterranean. Tectonics 17: 671-689.

Platt, J.P., Whitehouse, M.J., Kelley, S.P., Carter, A. \& Hollick, L., 2003. Simultaneous extensional exhumation across the Alboran Basin: implications for the causes of late orogenic extension. Geology 31: 251-254.

Platzman, E.S., 1992. Paleomagnetic rotations and the kinematics of the Gibraltar arc. Geology 20: 311-314.

Platzman, E.S., Platt, J.P. \& Olivier, P., 1993. Paleomagnetic rotations and fault kinematics in the Rif arc of Morocco. Journal of the Geological Society (London) 150: 707-718.

Platzmann, E., Platt, J.P., Kelley, S.P. \& Allerton, S., 2000. Large clockwise rotations in an extensional allochthon, Alboran Domain (southern Spain). Journal of the Geological Society (London) 157: 1187-1197.

Pratsch, J.-C., 1996. Oil and gas potential of the Prerif Foreland Basin, onshore northern Morocco. Journal of Petroleum Geology 19: 199-214.

Reicherter, K., 1999. Results from paleostress analysis of the Granada Basin (Southern Spain). Mitteilungen aus dem Geologisch-Paläontologische Institut der Universität Hamburg 83: 59-74.

Riaza, C. \& Martinez del Olmo, W., 1996. Depositional model of the Guadalquivir-Gulf of Cádiz Tertiary basin. In: Friend, P.F. \& Dabrio, C.J. (eds): Tertiary Basins of Spain: The Stratigraphic Record of Crustal Kinematics. Cambridge Univ. Press (Cambridge): 330-338.

Ribeiro, A., Cabral, J., Baptista, R. \& Matias, L., 1996. Stress pattern in Portugal mainland and the adjacent Atlantic region, West Iberia. Tectonics 15: 641-659.

Riding, R., Braga, J.C. \& Martín, J.M., 1999. Late Miocene Mediterranean desiccation: topography and significance of the 'Salinity Crisis' erosion surface on-land in southeast Spain. Sedimentary Geology 123: 1-7.

Rodríguez-Fernández, J., Sanz de Galdeano, C. \& Serrano, F., 1990. Le Couloir des Alpujarras. Documents et Travaux de l'IGAL 12-13: 87-100.

Roest, W.R. \& Srivastava, S.P., 1991. Kinematics of plate boundaries between Eurasia, Iberia and Africa in the N. Atlantic from the Late Cretaceous to the present. Geology 19: 613-616.

Roldán, F.J. \& Rodriguez-Fernández, J., 1991. Un ejemplo de cuenca piggyback asociada a la evolución neógena del frente de las Zonas Externas Béticas. I Congr. Grupo Español del Terciano, Com.: 297-300.
Rondeel, H.E., 1965. Geological Investigations in the Western Sierra Cabrera and Adjoining Areas, South-eastern Spain. Ph.D. Thesis, Univ. Amsterdam (Amsterdam): 161 pp.

Rosenbaum, G. \& Lister, G.S., 2004. Formation of arcuate orogenic belts in the western Mediterranean region. Geological Society of America Special Paper 383: 41-56.

Rosenbaum, G., Lister, G.S. \& Duboz, C., 2002. Relative motions of Africa, Iberia and Europe during Alpine orogeny. Tectonophysics 359: 117-129.

Rouchy, J.-M. \& Caruso, A., 2006. The Messinian salinity crisis in the Mediterranean basin: a reassessment of the data and an integrated scenario. Sedimentary Geology 188-189: 35-67.

Rouchy, J.-M., Piere, C., Et-Touhami, M., Kerzazi, K., Caruso, A. \& BlancValleron, M.-M., 2003. Late Messinian to Early Pliocene paleoenvironmental changes in the Melilla Basin (NE Morocco) and their relation to Mediterranean evolution. Sedimentary Geology 163: 1-27.

Royden, L.H., 1993. Evolution of retreating subduction boundaries formed during continental collision. Tectonics 12: 629-638.

Ruano, P., Bargach, K., Galindo-Zaldivar, J., Chalouan, A. \& Ahmamou, M., 2006. Recent palaeostresses from striated pebbles related to fold development in a mountain front: the Prerif Ridges (Rif Cordillera, Morocco). Geological Society Special Publication (London) 262: 87-99.

Samaka, F., Benyaïch, A., Dakki, M., Hcaine, M. \& Bally, A.W., 1997. Origine et inversion des bassins miocènes supra-nappes du Rif Central (Maroc): étude de surface et de subsurface. Geodinamica Acta 10: 30-40.

Sánchez-Gómez, M., García-Dueñas, V., Muñoz, M. \& Balanyá, J.C., 1995. Relación estructural entre los cuerpos peridotíticos situados al Norte y al Sur del Estrecho de Gibraltar. Geogaceta 17: 135-137.

Sani, F., Zizi, M. \& Bally, A.W., 2000. The Neogene-Quaternary evolution of the Guercif Basin (Morocco) reconstructed from seismic line interpretation. Marine and Petroleum Geology 17: 343-357.

Sanz de Galdeano, C., 1983. Los accidentes y fracturas principales de las Cordilleras Béticas. Estudios Geológicos 39: 157-165.

Sanz de Galdeano, C., 1988. The evolution, importance and significance of the Neogene fault system within the Betic-Rifean Domain. Mediterránea: Serie de Estudios Geológicos 7: 33-43.

Sanz de Galdeano, C., 1990a. La prolongación hacia el sur de las fosas y desgarres del norte y centro de Europa: una propuesta de interpretación. Revista Sociedad de la Geológica de España 3: 231-241.

Sanz de Galdeano, C., 1990b. Geologic evolution of the Betic Cordilleras in the Western Mediterranean, Miocene to the present. Tectonophysics 172: 107-119.

Sanz de Galdeano, C., 1991. Una propuesta de clasificación de las cuencas neógenas béticas. Acta Geológica Hispana 26: 205-227.

Sanz de Galdeano, C., 1996a. The E-W segments of the contact between the External and Internal Zones of the Betic and Rif cordilleras and the $\mathrm{E}-\mathrm{W}$ corridors of the Internal Zone (a combined explanation). Estudios Geológicos 52: 123-136.

Sanz de Galdeano, C., 1996b. Tertiary tectonic framework of the Iberian Peninsula. In: Friend, P.F. \& Dabrio, C.J. (eds): Tertiary Basins of Spain: The Stratigraphic Record of Crustal Kinematics. Cambridge Univ. Press (Cambridge): 9-14.

Sanz de Galdeano, C., 1997. La Zona Interna Bético-Rifeña (antecedentes, unidades tectónicas, correlaciones y bosquejo de reconstrucción paleogeográfica). Monografias Tierras del Sur (Universidad Granada) 18: $316 \mathrm{pp}$. 
Sanz de Galdeano, C., 2000. Evolution of Iberia during the Cenozoic with special emphasis on the formation of the Betic Cordillera and its relation with the western Mediterranean. Ciûncias da Terra 14: 9-24.

Sanz de Galdeano, C. \& López-Garrido, A.C., 1991. Tectonic evolution of the Malaga basin (Betic Cordillera): Regional implications. Geodinamica Acta 5: 173-186.

Sanz de Galdeano, C. \& López-Garrido, A.C., 1999. Nature and impact of the neotectonic deformation in the western Sierra Nevada (Spain). Geomorphology 30: 259-272.

Sanz de Galdeano, C. \& López-Garrido, A.C., 2000. Las fallas tortonienses a cuaternarias entre Granada y la costa: el límite occidental del NevadoFilábride y de las unidades alpujárrides inferiores. Revista de la Sociedad Geológica de España 13: 519-528.

Sanz de Galdeano, C. \& Vera, J.A., 1991. Una propuesta de clasificatión de la cuencas neógenas béticas. Acta Geologica Hispanica 26 : 205-227.

Sanz de Galdeano, C. \& Vera, J.A., 1992. Stratigraphic record and palaeogeographical context of the Neogene basins in the Betic Cordillera, Spain. Basin Research 4: 21-36.

Sanz de Galdeano, C., Vidal, F. \& de Miguel, F., 1982. El sistema de fracturas de dirección N10-30 e del borde occidental de Sierra Nevada (Cordilleras Béticas). Estudios Geológicos 38: 393-398.

Sanz de Galdeano, C., Estévez, A., López-Garrido, A.C. \& Rodríguez-Fernández, J., 1984. La fracturación tardia al SW de Sierra Nevada (terminación occidental del corredor de las Alpujarras, Zona Bética). Estudios Geológicos 40: 1983-192.

Sanz de Galdeano, C., Rodríguez-Fernández, J. \& López-Garrido, A.C., 1985. A strike-slip fault corridor within the Alpujarra mountains (Betic Cordilleras, Spain). Geologische Rundschau 74: 641-655.

Sanz de Galdeano, C., Rodríguez-Fernández, J. \& López-Garrido, A.C., 1986. Tectonosedimentary evolution of the Alpujarran corridor (Betic Cordilleras, Spain). Gionale di Geologia 3, 48: 85-90.

Sanz de Galdeano, C., Serrano, F., López-Garrido, A.C. \& Martín Pérez, J.A., 1993. Palaeogeography of the Late Aquitanian-Early Burdigalian basin in the western Betic Internal Zone. Geobios 26: 43-55.

Sanz de Galdeano, C., López Casado, C. Delgado, J. \& Peinado, M.A., 1995. Shallow seismicity and active faults in the Betic Cordillera. A preliminary approach to seismic sources associated with specific faults. Tectonophysics 248: 293-302.

Scotney, P., Burgess, R. \& Rutter, E.H., 2000. 40Ar/39Ar age of the Cabo de Gata volcanic series and displacements on the Carboneras fault zone, SE Spain. Journal of the Geological Society (London) 157: 1003-1008.

Seber, D., Barazangi, M., Ibenbrahim, A. \& Demnati, A., 1996. Geophysical evidence for lithospheric delamination beneath the Alboran Sea and RifBetic mountains. Nature 379: 785-790.

Serrano, F., Guerra-Merchán, A., El Kadiri, K., Sanz de Galdeano, C., LópezGarrido, Á.C., Mártin-Mártin, M. \& Hlila, R., 2007. Tectono-sedimentary setting of the Oligocene-early Miocene deposits on the Betic-Rifian Internal Zone (Spain and Morocco). Geobios 40: 191-205.

Serrano Lozano, F., 1980. Los materiales del Mioceno superior de la cuenca de Ronda (Malaga). Estudios Geológicos 36: 231-236.
Servant-Vildary, S., Rouchy, J.M., Pierre, C. \& Foucault, A., 1990. Marine and continental water contributions to a hypersaline basin using diatom ecology, sedimentology and stable isotopes: an example in the Late Miocene of the Mediterranean. Palaeogeography, Palaeoclimatology, Palaeoecology 79: 189-204.

Sierro, F.J., González Delgado, J.A., Dabrio, C.J. Flores, J.A. \& Civis, J., 1996. Late Neogene depositional sequences in the foreland basin of Guadalquivir (SW Spain). In: Friend, P. \& Dabrio, C.J. (eds): Tertiary Basins of Spain: The Stratigraphic Record of Crustal Kinematics. Cambridge Univ. Press (Cambridge): 339-345.

Silva, P.G., Goy, J.L. \& Zazo, C., 1992. Características estructurales y geométricas de la falle de desgarre de Lorca-Alhama. Geogaceta 12: 7-11.

Sissingh, W., 2006. Kinematic sequence stratigraphy of the European Cenozoic Rift System and Alpine Foreland Basin: correlation with Mediterranean and Atlantic plate-boundary events. Netherlands Journal of Geosciences, 85: 77-129.

Soria, J.M., 1994. Sedimentación y tectónica durante el Mioceno en la región de Sierra Arana-Mencal y su relación con la evolución geodinámica de Cordillera Bética. Revista de la Sociedad Geológica de España 7: 199-213.

Soria, J.M., 1998. La Cuenca de Antepaís Norbética en la Cordillera Bética Central (sector del Mencal): evolución tectosedimentaria e historia de la subsidencia. Revista de la Sociedad Geológica de España 11: 23-31.

Soria, J.M., Viseras, C. \& Fernández, J., 1998. Late Miocene-Pleistocene tectonosedimentary evolution and subsidence history of the central Betic Cordillera (Spain): a case study in the Guadix intramontane basin. Geological Magazine 135: 565-574.

Soria, J.M., Fernández, J. \& Viseras, C., 1999. Late Miocene stratigraphy and palaeogeographic evolution of the intramontane Guadix Basin (Central Betic Cordillera, Spain): implications for an Atlantic-Mediterranean connection. Palaeogeography, Palaeoclimatology, Palaeoecology 151: 255-266.

Soria, J.M., Alfaro, P., Fernández, J. \& Viseras, C., 2001. Quantitative subsidence-uplift analysis of the Bajo Segura Basin (eastern Betic Cordillera, Spain): tectonic control on the stratigraphic architecture. Sedimentary Geology. 140: 271-289.

Spakman, W. \& Wortel, R., 2004. A tomographic view on Western Mediterranean geodynamics. In: Cavazza, W., Roure, F.M., Spakman, W., Stampfli, G.M. \& Ziegler, P.A. (eds): The Transmed Atlas: The Mediterranean Region from Crust to Mantle. Springer (Berlin): 31-52.

Srivastava, S.P., Roest, W.R., Kovacs, Oakey, G., Lévesque, Verhoef, J. \& Macnab, R., 1990. Motion of Iberia since the Late Jurassic: results from detailed aeromagnetic measurements in the Newfoundland Basin. Tectonophysics 184, 229-260.

Stapel, G., Moeys, R. \& Biermann, C., 1996. Neogene evolution of the Sorbas basin (SE Spain) determined by paleostress analysis. Tectonophysics 255: 291-305.

Stokes, M. \& Mather, A.E., 2000. Response of Plio-Pleistocene alluvial systems to tectonically induced base-level changes, Vera Basin, SE Spain. Journal of the Geological Society (London) 157: 303-316.

Stromberg, S.G. \& Bluck, B., 1998. Turbidite facies, fluid-escape structures and mechanisms of emplacement of the Oligo-Miocene Aljibe Flysch, Gibraltar Arc, Betics, southern Spain. Sedimentary Geology 115: 267-288. 
Tandon, K., Fernández, M., Comas, M.C. \& De La Linde, J., 1998. Timing of rifting in the Alboran Sea basin - Correlation of borehole (ODP Leg 161 and Andalucia A-1) to seismic reflection data: implications for basin formation. Marine Geology 144: 275-294.

Tejera de Leon, J., Boutakiout, M., Ammar, A., Aït Brahim, L. \& El Hatimi, N., 1995. Les bassins du Rif central (Maroc): marquers de chevauchements hors séquence d'âge miocène terminal au c?ur de la chaîne. Bulletin de la Société Géologique de France 166: 751-761.

Tent-Manclús, J.E., Martín-Martín, M., Martín-Pérez, J.A. \& Serrano, F. 2001. Structural evolution of the early Miocene in the eastern Betic internal-external zone boundary (SE Spain). Bulletin de la Société Géologique de France 172: 41-47.

Torelli, L., Sartori, R. \& Zitellini, N., 1997. The giant chaotic body in the Atlantic Ocean off Gibraltar: new results from a deep seismic reflection survey. Marine and Petroleum Geology 14: 125-138.

Torné, M., Fernàndez, M., Comas, M.C. \& Soto, J.I., 2000. Lithospheric structure beneath the Alboran Basin: results from 3D gravity modeling and tectonic relevance. Journal of Geophysical Research B, 105: 3209-3228.

Torres-Roldán, R.L., Poli, G. \& Peccerillo, A., 1986. An Early Miocene arc-tholeitic magmatic dike event from the Alboran Sea - Evidence for precollisional subduction and back-arc crustal extension in the easternmost Mediterranean. Geologische Rundschau 75: 219-234.

Van de Poel, H.M., 1994. Messinian marginal-marine and continental facies and their stratigraphy in the eastern Almeria Province (S.E. Spain). Strata 2, 23 : $202 \mathrm{pp}$.

Van der Beek, P.A. \& Cloetingh, S., 1992. Lithospheric flexure and the tectonic evolution of the Betic Cordilleras (SE Spain). Tectonophysics 203: 325-344.

Van der Straaten, H.C., 1990. The Albarán Basin - A Neogene Pull-apart Basin in SE Spain. Ph.D. Thesis, Free Univ. (Amsterdam): 193 pp.

Van der Straaten, H.C., 1993. Neogene strike-slip faulting in southeastern Spain: the deformation of the pull-apart basin of Albáran. Geologie en Mijnbouw 71: 205-225.

Veeken, P.C.H., 1983. Stratigraphy of the Neogene-Quaternary Pulpi Basin, provinces Murcia and Almeria (SE Spain). Geologie en Mijnbouw 62: 255-265.

Vergés, J. \& Sàbat, F., 1999. Constraints on the Neogene Mediterranean kinematic evolution along a $1000 \mathrm{~km}$ transect from Iberia to Africa. Geological Society Special Publication (London) 156: 63-80.

Vissers, R.L.M., Platt, J.P. \& Van der Wal, D., 1995. Late orogenic extension of the Betic Cordillera and the Alboran Domain: a lithospheric view. Tectonics 14: 786-803

Völk, H.R., 1967. Zur Geologie und Stratigraphie des Neogensbeckens von Vera, Südost-Spanien. Ph.D. Thesis, Univ. Amsterdam (Amsterdam): 161 pp.

Völk, H.R. \& Rondeel, H.E., 1964. Zur Gliederung des Jungtertiärs im Becken von Vera, Südostspanien. Geologie en Mijnbouw 43: 310-315.

Warny, S.A., Bart, P.J. \& Suc, J.-P., 2003. Timing and progression of climatic, tectonic and glacioeustatic influences on he Messinian Salinity Crisis. Palaeogeography, Palaeoclimatology, Palaeoecology 202: 59-66.

Watts, A.B., Platt, J.P. \& Buhl, P., 1993. Tectonic evolution of the Alboran Sea basin. Basin Research 5; 153-177.

Weijermars, $\boldsymbol{R} .$, 1987. The Palomares brittle-ductile shear zone of southern Spain. Journal of Structural Geology 9: 139-157.
Weijermars, R., Roep, T.B., Van den Eeckhout, B., Postma, G. \& Kleverlaan,

K., 1985. Uplift history of a Betic fold nappe inferred from NeogeneQuaternary sedimentation and tectonics (in the Sierra Alhamilla and Almería, Sorbas and Tabernas Basins of the Betic Cordilleras, SE Spain). Geologie en Mijnbouw 64: 397-411.

Wildi, W., 1983. La chaîne tello-rifaine (Algérie, Maroc, Tunisie): structure, stratigraphie et évolution du Trias au Miocène. Revue de Géologie Dynamique et de Géographie Physique 24: 201-297.

Wrobel, F., 2000. Das Lorca-Becken (Obermiozän, SE-Spanien) - Faziesinterpretation, Sequenzstratigraphie, Beckenanalyse. Geologische Beiträge Hannover 1: $141 \mathrm{pp}$.

Wrobel, F. \& Michalzik, D., 1999. Facies successions in the pre-evaporitic Late Miocene of the Lorca Basin, SE Spain. Sedimentary Geology 127: 171-191.

Yahyaoui, A.M., Dakki, M., Hoepffner, C. \& Demnati, A., 1997. Le Bassin du Gareb-Bou Areg (Rif oriental): une région-clé pour l'interprétation de la structuration alpine de chaîne rifaine. Géologie Méditerranée 24, 73-92.

Zaghloul, M.N., Gigliuto, L.G., Puglisi, D., Ouazani-Touhami, A. \& Belkaid, A., 2003. The Oligocene-Miocene Ghomaride cover: a petro-sedimentary record of an early subsident stage related to the Alboran Sea rifting (northern Internal Rif, Morocco). Geologica Carpathica 54: 93-105.

Zeck, H.P., 1997. Mantle peridotites outlining the Gibraltar Arc - Centrifugal extensional allochthons derived from the earlier Alpine, westward subducted nappe pile. Tectonophysics 281: 195-207.

Zeck, H.P., 1999. Alpine plate kinematics in the western Mediterranean: a westward-directed subduction regime followed by slab roll-back and slab detachment. Geological Society Special Publication (London) 156: 109-120.

Zeck, H.P., Maluski, H. \& Kristensen, A.B., 2000. Revised geochronology of the Neogene calc-alkaline volcanic suite in Sierra de Gata, Alborán volcanic province, SE Spain. Journal of the Geological Society (London) 157: 75-81. 


\section{Appendix 1 - Paleogeographic reconstruction for the late Aquitanian}

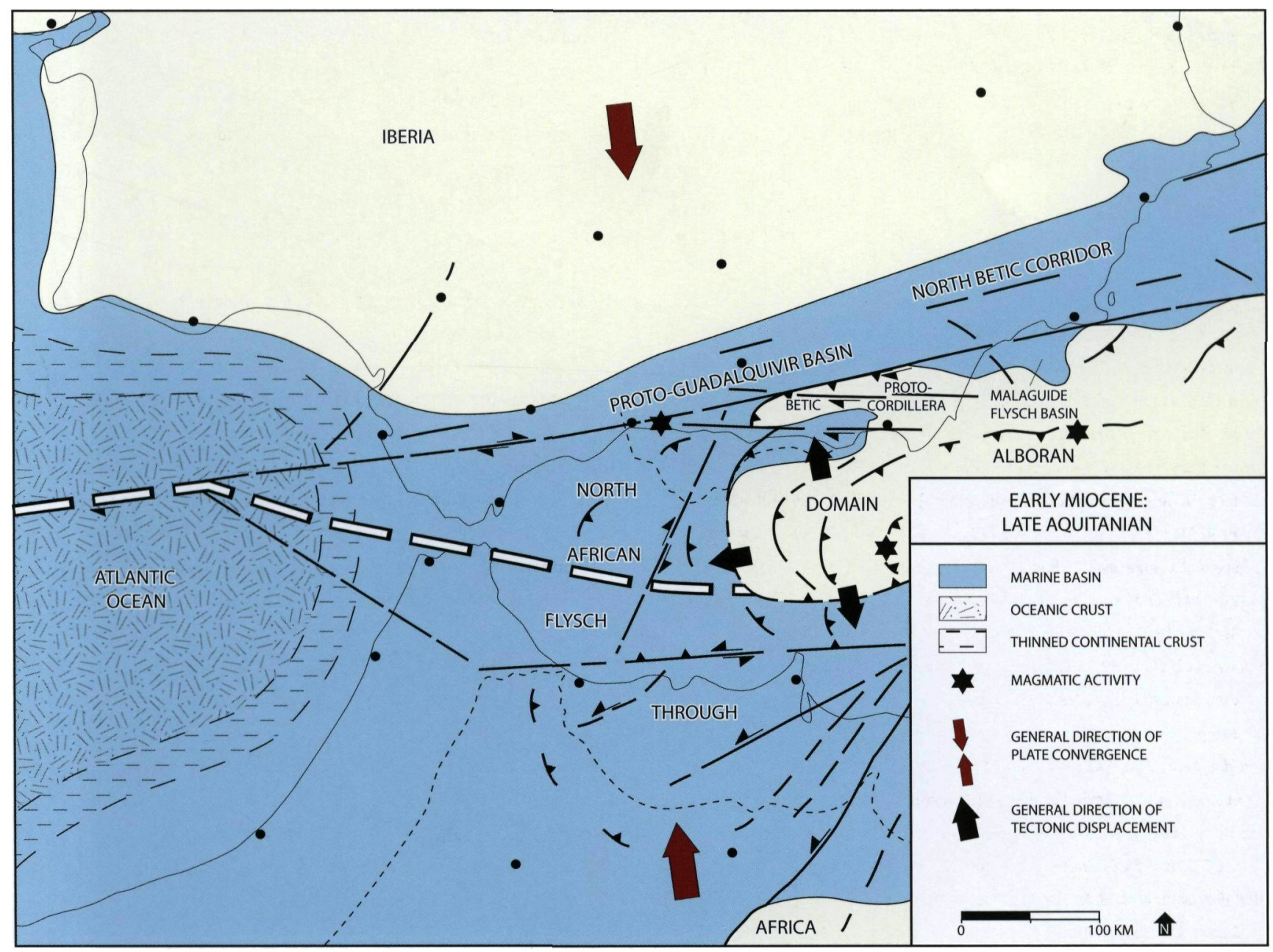




\section{Appendix 2 - Paleogeographic reconstruction for the late Burdigalian}

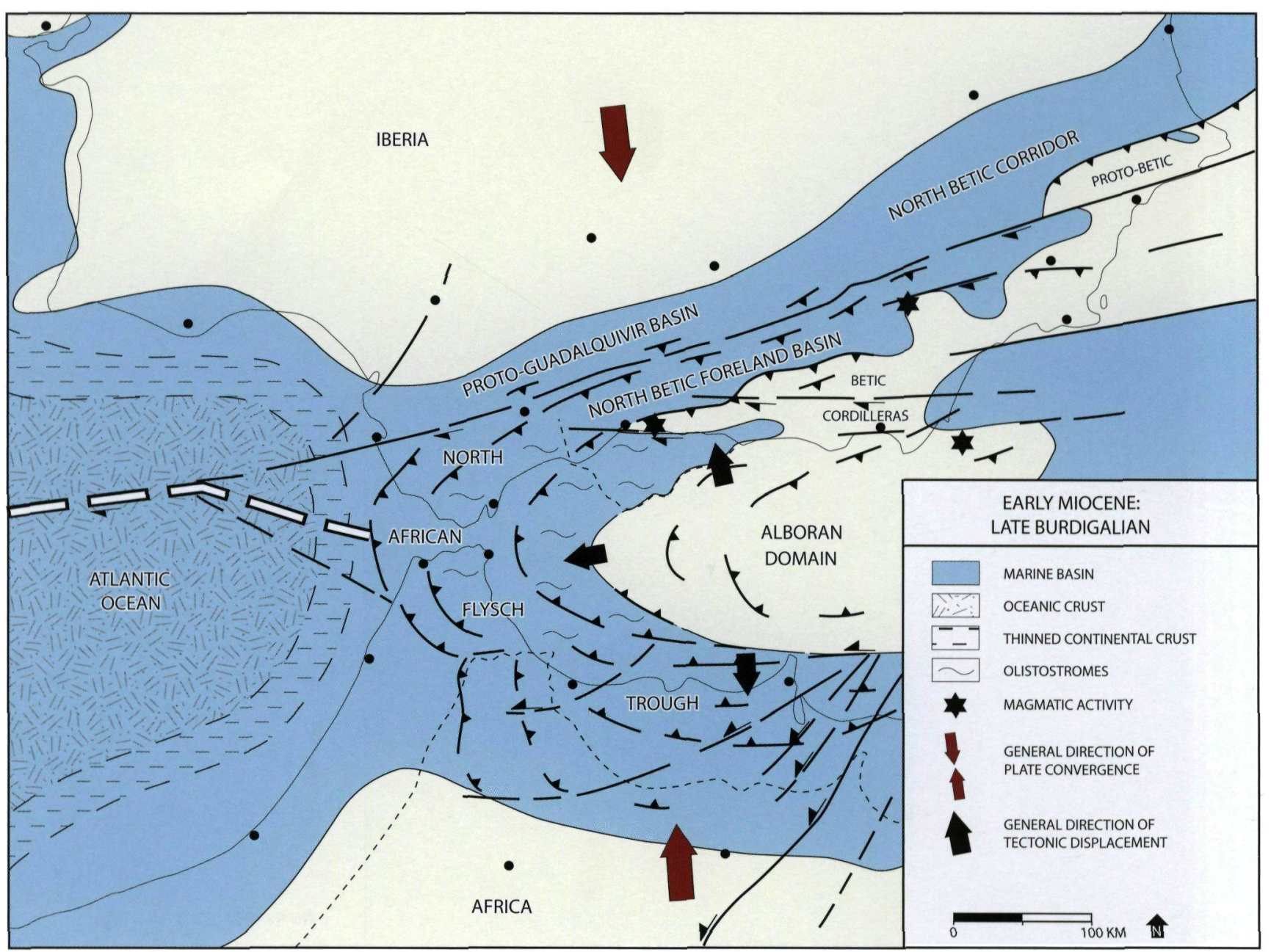




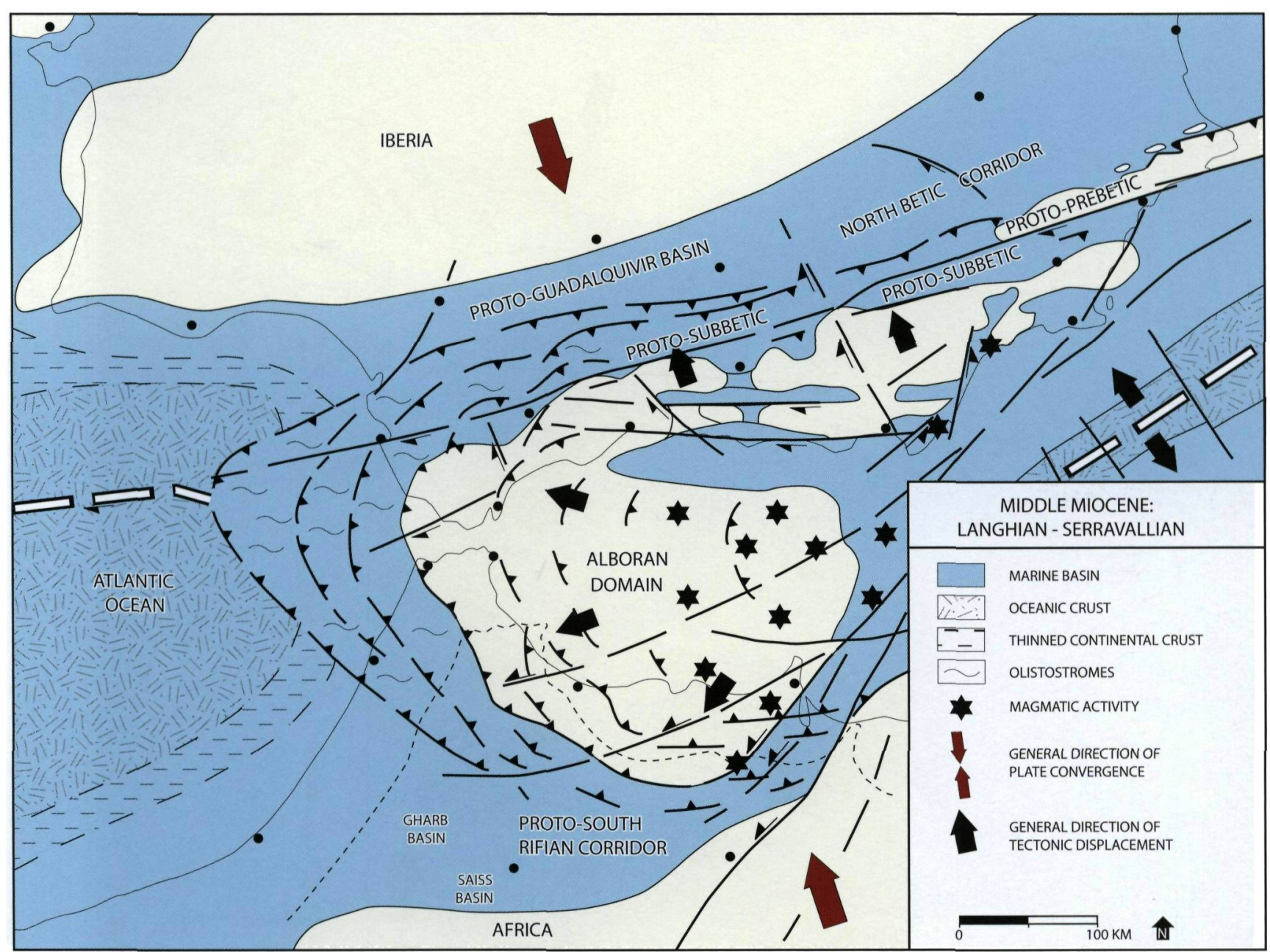




\section{Appendix 4 - Paleogeographic reconstruction for the late Tortonian}

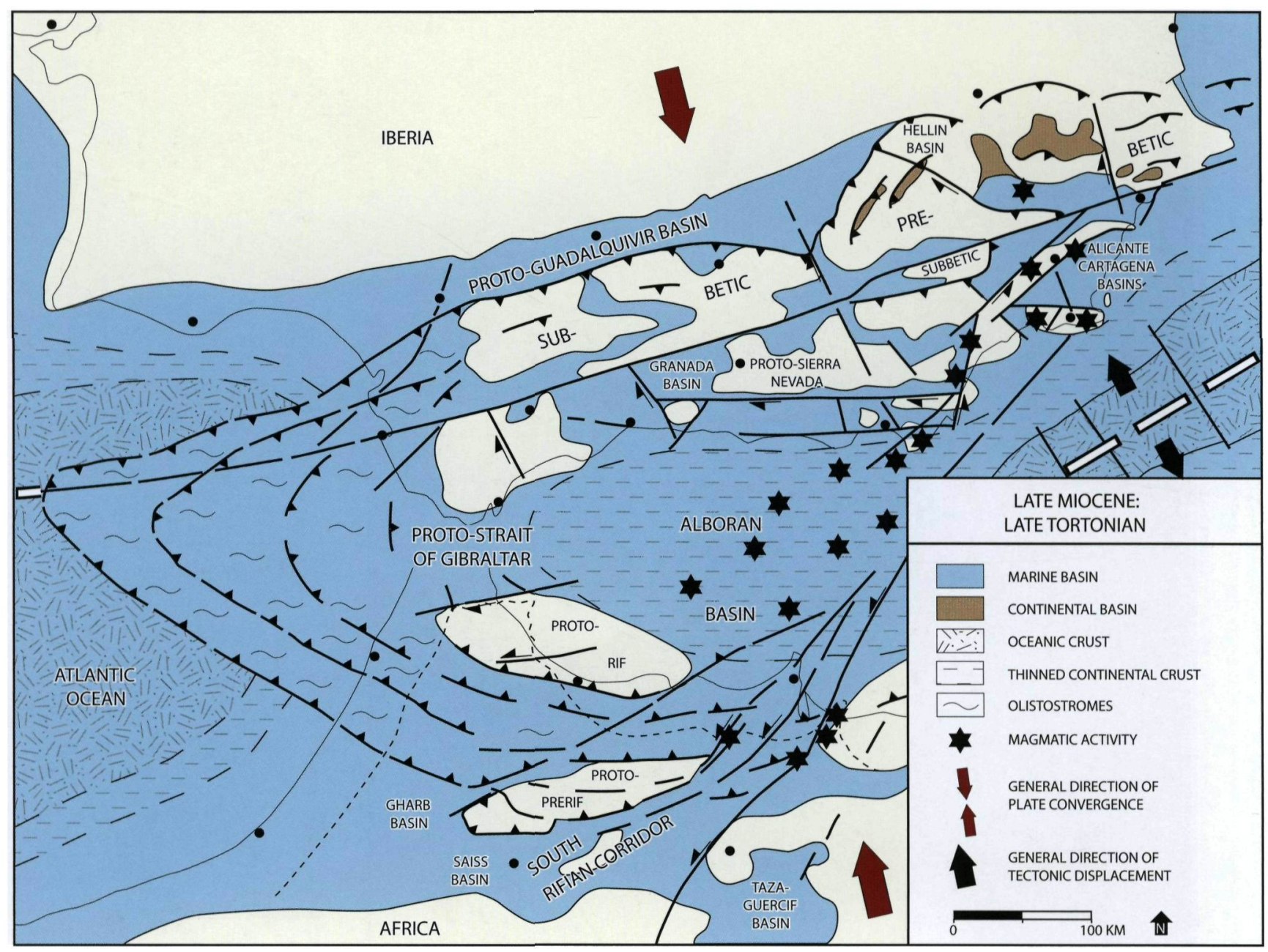




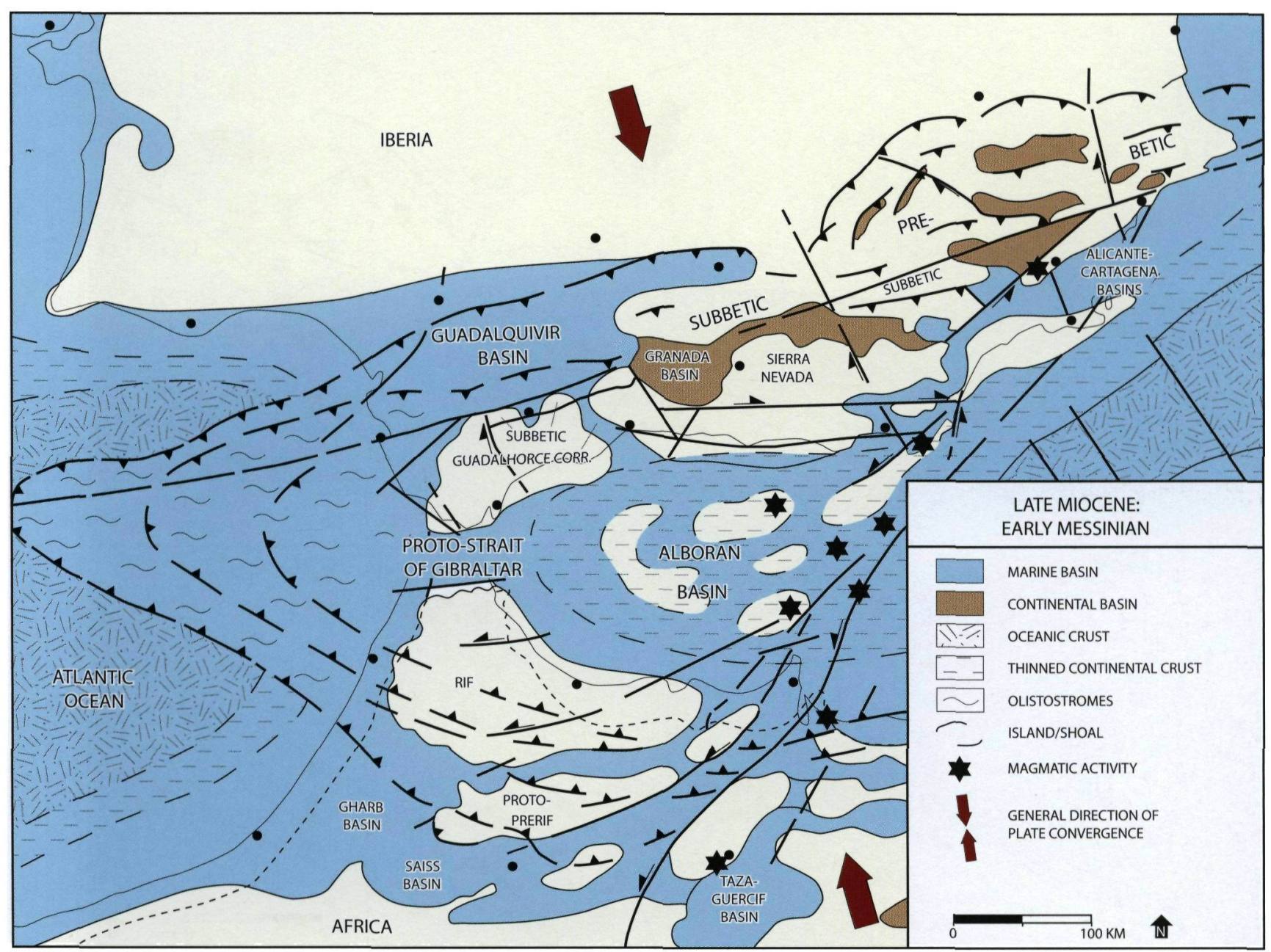




\section{Appendix 6 - Paleogeographic reconstruction for the late Messinian (early-middle part)}

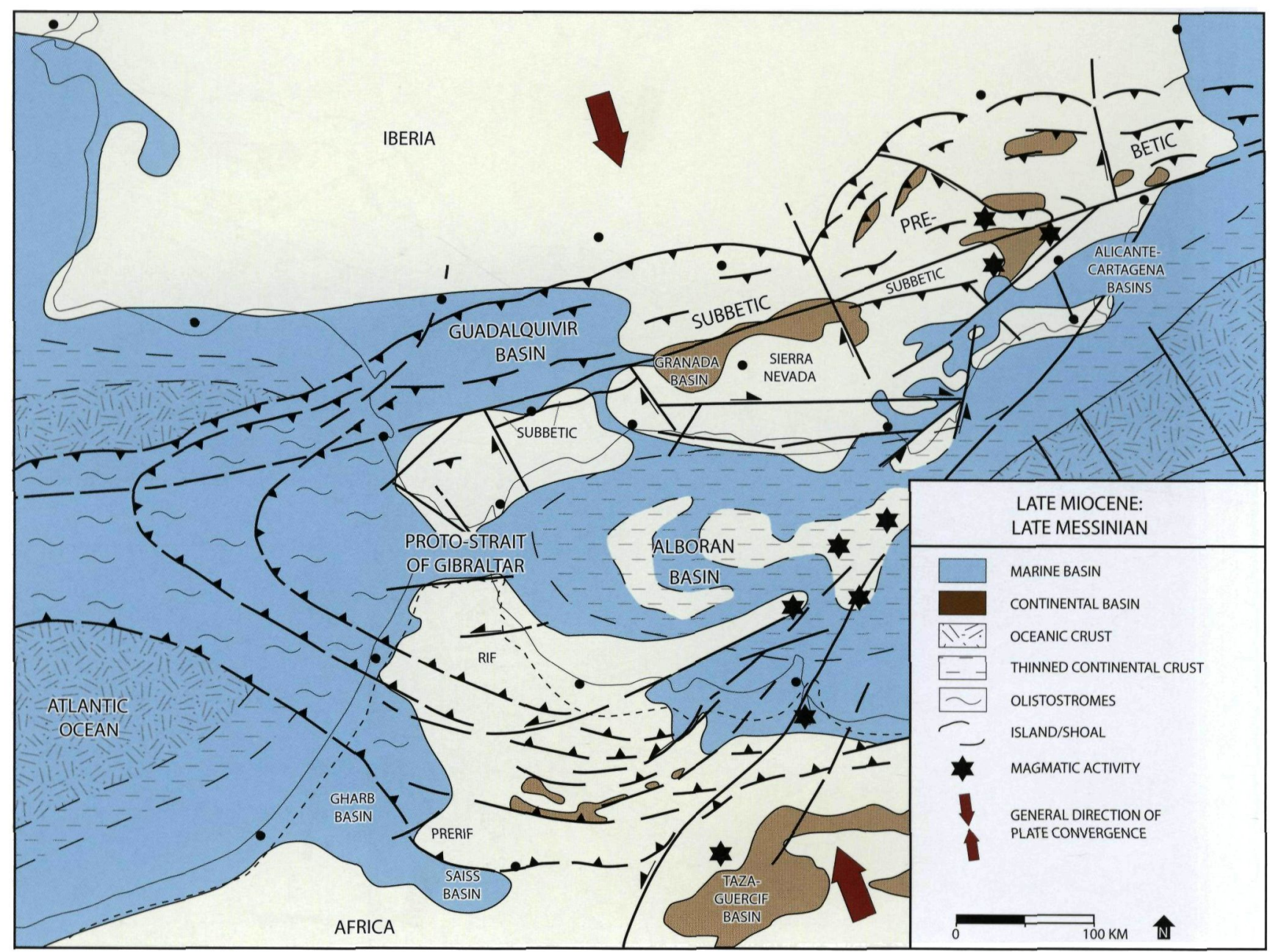




\section{Appendix 7 - Paleogeographic reconstruction for the Zanclean}

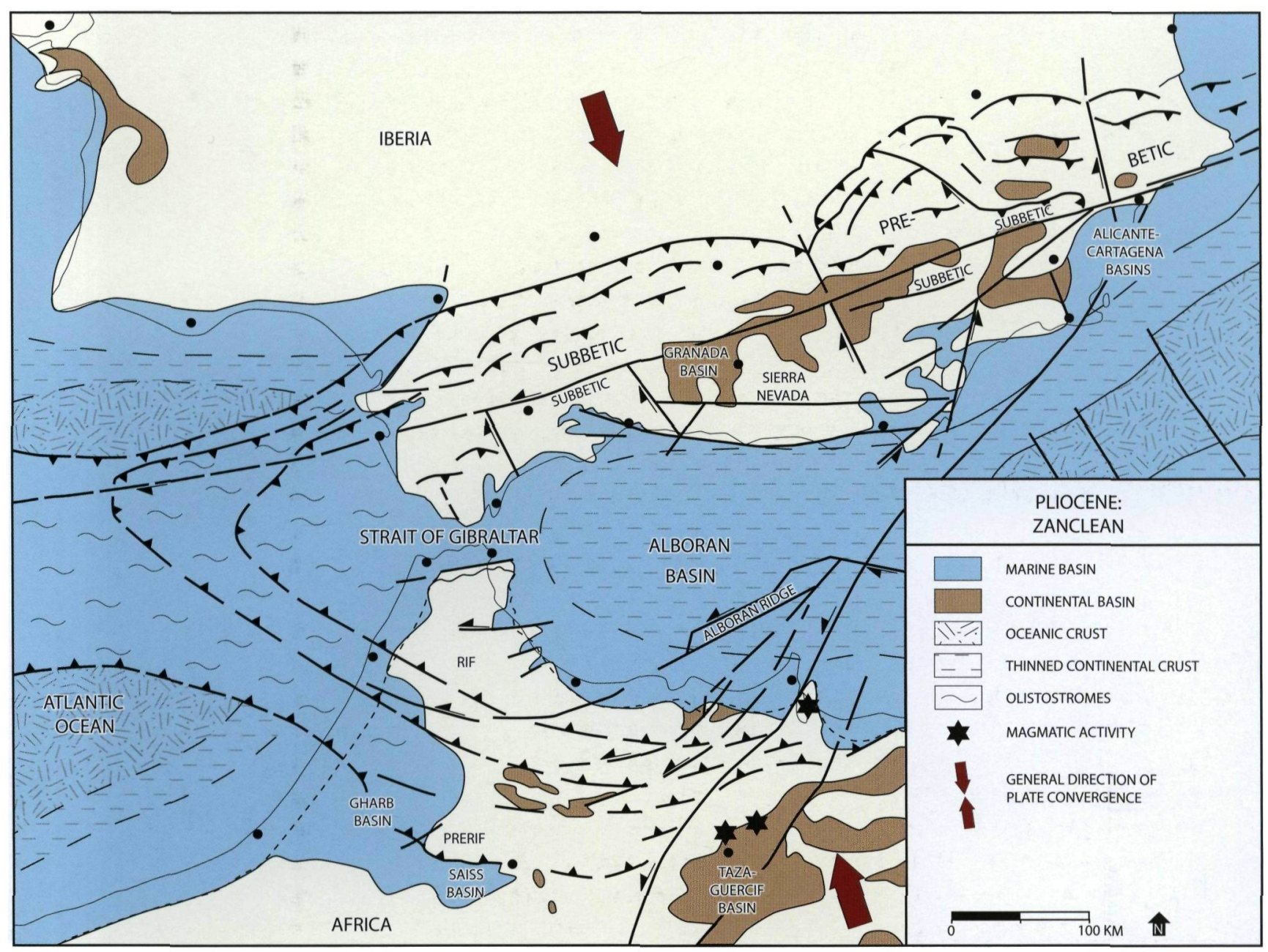

